Florida International University FIU Digital Commons

\title{
Heavenly Voice, Earthly Echo: Unraveling the Function of the Bat Kol in Rabbinic Writings
}

John D. Grullon

Florida International University, jgrullon21@gmail.com

DOI: 10.25148 /etd.FIDC000239

Follow this and additional works at: https:// digitalcommons.fiu.edu/etd

Part of the Biblical Studies Commons, and the Jewish Studies Commons

\section{Recommended Citation}

Grullon, John D., "Heavenly Voice, Earthly Echo: Unraveling the Function of the Bat Kol in Rabbinic Writings" (2016). FIU Electronic Theses and Dissertations. 2466.

https://digitalcommons.fiu.edu/etd/2466 


\title{
FLORIDA INTERNATIONAL UNIVERSITY
}

Miami, Florida

\section{HEAVENLY VOICE, EARTHLY ECHO: UNRAVELING THE FUNCTION OF THE BAT KOL IN RABBINIC WRITINGS}

\author{
A thesis submitted in partial fulfillment of the \\ requirements for the degree of \\ MASTER OF ARTS \\ in \\ RELIGIOUS STUDIES \\ by \\ John David Grullon
}

2016 
To: Dean John Stack

School of International and Public Affairs

This thesis, written by John David Grullon, and entitled Heavenly Voice, Earthly Echo: Unraveling the Function of the Bat Kol in the Rabbinic Writings, having been approved in respect to style and intellectual content, is referred to you for judgment.

We have read this thesis and recommend that it be approved.

Tudor Parfitt

Oren Stier

Erik Larson, Major Professor

Date of Defense: March 30, 2016

The thesis of John David Grullon is approved.

Dean John Stack

School of International and Public Affairs

Andrés G. Gil

Vice President for Research and Economic Development and Dean of the University Graduate School

Florida International University, 2016 
(C) Copyright 2016 by John David Grullon

All rights reserved. 


\section{ACKNOWLEDGMENTS}

I would like to thank the Department of Religious Studies at Florida International University for providing the opportunity to complete this program as a teaching assistant. I have benefited much from assisting Professors with their classes. Moreover, I have enjoyed getting to know the faculty, staff, and students in the Department. I am thankful for learning that has occurred both in and outside the classroom.

I would like to thank my major Professor Dr. Erik Larson. He has consistently assisted me with precise and thorough feedback on this thesis and has always made himself available whenever I sought to speak with him. I am grateful for his continued involvement and guidance.

I would like to thank Dr. Oren Stier who has been diligent in helping me stay on track throughout the writing process. I am thankful for his feedback, edits, and encouraging remarks.

I would like to thank Dr. Tudor Parfitt who also provided insightful suggestions in the development and structure of this project.

Lastly, I would like to thank Dr. Roberto Pacheco, who has been another constant voice of guidance and support. I am grateful for his involvement in proofreading each chapter and providing feedback on grammar and content. 
ABSTRACT OF THE THESIS

HEAVENLY VOICE, EARTHLY ECHO: UNRAVELING THE FUNCTION OF THE BAT KOL IN RABBINIC WRITINGS

\author{
by \\ John David Grullon \\ Florida International University, 2016 \\ Miami, Florida \\ Professor Erik Larson
}

There is an ancient rabbinic apothegm which asserts that prophecy ceased after the last Biblical prophets, Haggai, Zachariah, and Malachi. After their deaths, a new phase of divine revelation was believed to have emerged through manifestations of a bat kol (lit. "Daughter of a voice”). This thesis examines the bat kol's function within the contours of the Babylonian Talmud, primarily, employing philological, literary, and historical analyses. Moreover, it includes a review of parallels with Biblical and SecondTemple era, Apocalyptic works, so as to suggest possible origins. In addition, a sample of about ten stories are presented as representative of larger categories I consider best exhibit the bat kol's purpose. The categories include: announcing an individual's entry into the world to come, encomium and disdain towards individuals, matters related to Halacha (Jewish Law), and miscellaneous. As a result we discover how the rabbis employed the bat kol to address contemporary concerns. 


\section{TABLE OF CONTENTS}

CHAPTER

PAGE

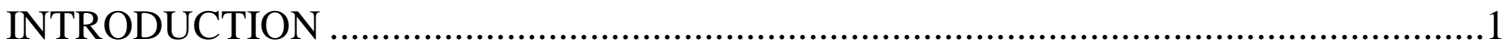

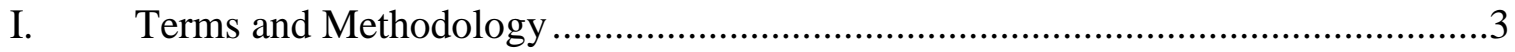

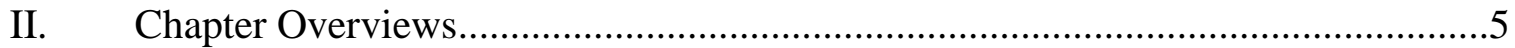

A. Literature Review: .....................................................................

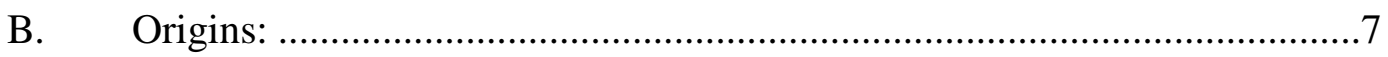

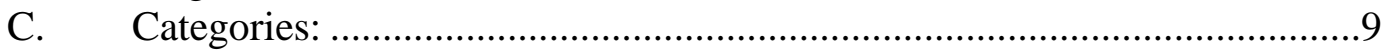

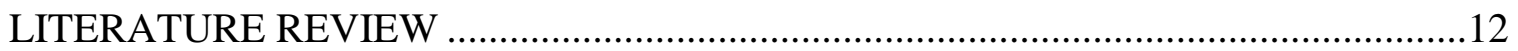

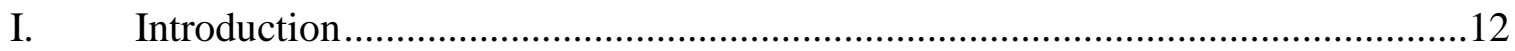

II. Cyclopedia of Biblical Literature (article by John Nicholson, 1858) .....................13

III. "Ancient Traditions of Supernatural Voices (Bath-Kol)" (article by S. Louis,

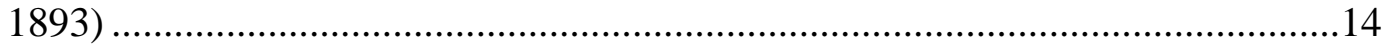

IV. $\quad$ From Letter to Spirit by Edwin A. Abbott (1903) …………………….................15

V. Jewish Encyclopedia (article by Ludwig Blau and Kauffmann Kohler, 1906) .....17

VI. Judaism in the First Centuries of the Christian Era by George F. Moore (1927)..19

VII. The Significance of Miracles in Talmudic Judaism by Alexander Guttmann

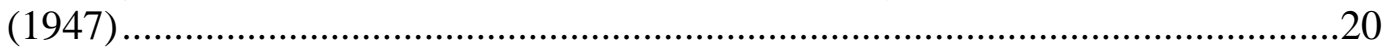

VIII. Studies in Jewish Theology by Arthur Marmorstein (1950) .................................21

IX. Hellenism in Jewish Palestine by Saul Lieberman (1950).....................................22

X. The Rabbinic Mind by Max Kadushin (1952) .....................................................24

XI. Prophetic Inspiration after the Prophets by Abraham J. Heschel (1966)................24

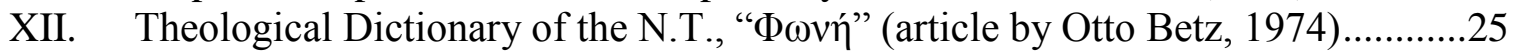

XIII. Essays in Jewish Thought by Nahum Glatzer (1978) ............................................27

XIV. Revelation and Mystery in Ancient Judaism and Pauline Christianity by Markus Bockmuehl (1990) .......................................................................................28

XV. Prophetic Figures in Late Second Temple Jewish Palestine by Rebecca Gray

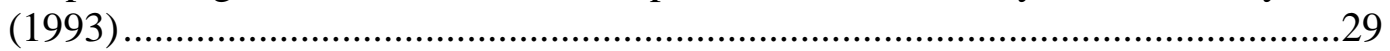

XVI. The Sinner and the Amnesiac by Alon Goshen Gottstein (2000)...........................31

XVII. Encyclopedia Judaica "Bat Kol” (article by Aaron Rothkoff, 2007)......................33

XVIII. Elijah and the Rabbis by Kristen H. Lindbeck (2010)...........................................33

XVIIII.On the Question of the "Cessation of Prophecy" in Ancient Judaism by L. Stephen Cook (2011) ...........................................................................................

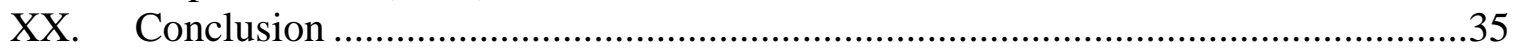

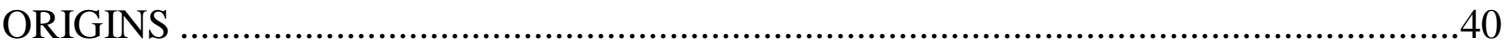

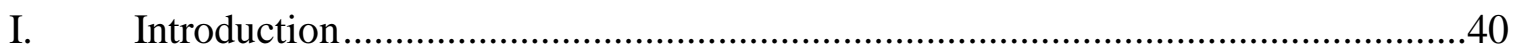

A. End of Prophecy .................................................................................4

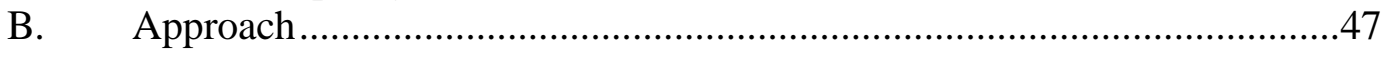

II. Rabbinic Literary Categories, Biblical and Apocalyptic Literatures......................48 


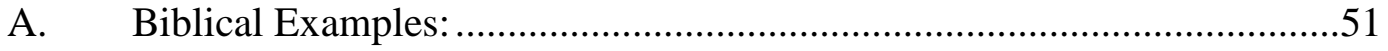

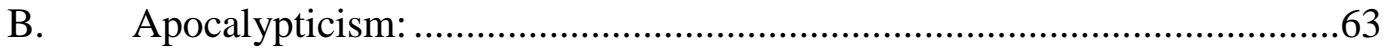

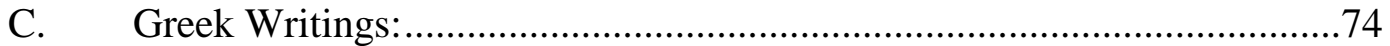

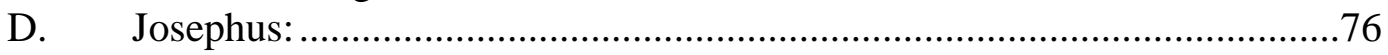

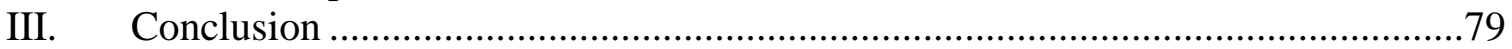

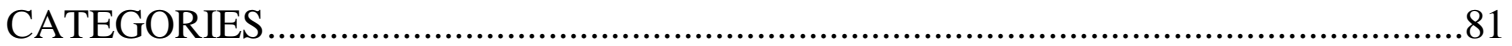

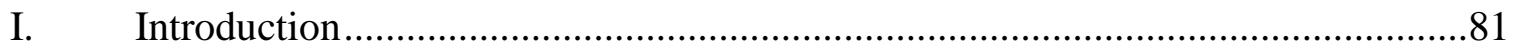

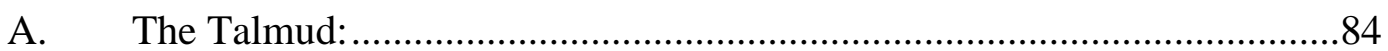

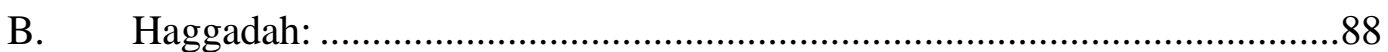

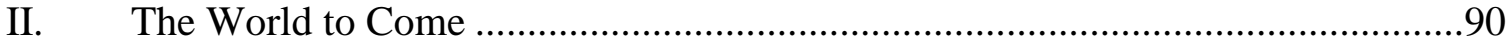

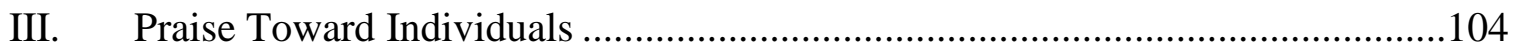

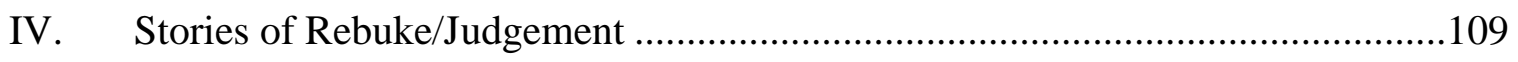

A. Retrojected on to Biblical Figures: .....................................................109

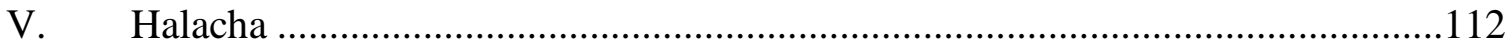

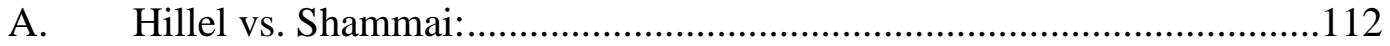

B. Rabbinic Authority and Morality ........................................................117

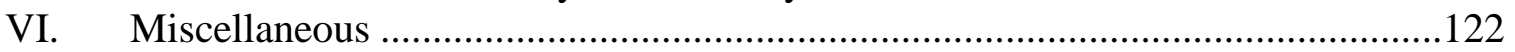

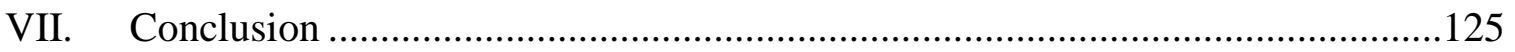

CONCLUSION

I. Summary of LITERATURE REVIEW chapter ...........................................130

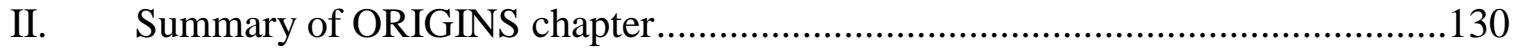

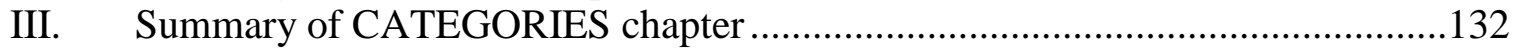

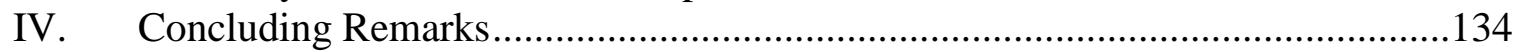

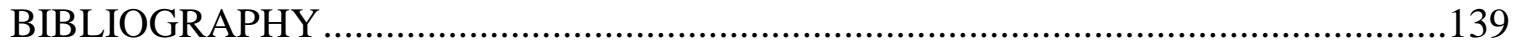




\section{TRACTATE ABBREVIATIONS}

Ber. Berachot

Sh. Shabbat

Er. Eruvin

Pe. Pesachim

Yo. Yoma

R.H. Rosh Hashannah

Ta. Ta’anit

Meg. Megillah

M.K. Moed Katan

Chg. Chagigah

Yev. Yevamot

Ket. Ketubot

So. Sotah

Git. Gittin

B.M. Bava Metzia

B.B. Bava Batra

Sa. Sanhedrin

A.Z. Avodah Zarah

Hr. Horayot

Mak. Makkot

Chl. Chullin

Ker. Keritot 


\section{INTRODUCTION}

Perhaps every individual has experienced a point in time in which he or she longed for a supernatural sign; a clue, a word, a marvel, anything that would indicate the right path to follow; or a word a word of encouragement, comfort, and affirmation in challenging times. Indeed, part of being human means being ignorant of what tomorrow holds; we can only engage with the moment at hand, which nevertheless has direct bearing on the future. In an effort to reach our intended destinations while minimizing detours, we carefully weigh out decisions, consult trusted friends, and look for tokens that might be construed as heavenly signs. Perhaps some can even attest to the legitimacy and subsequent success of such a search. People in the ancient world were no different, for they too sought out divine signs and communication in various means. This thesis will explore one such medium as related in rabbinic literature, namely, the bat kol.

The bat kol (literally “daughter of a voice") ${ }^{1}$ is understood as one of God's divine attributes. ${ }^{2}$ As a divine agent it is meant to fulfill certain tasks on God's behalf. This thesis is concerned with exploring the role of the bat kol within the rabbinic stories of the Babylonian Talmud. It is my view that the rabbis' employment of the bat kol is best understood as a means of moralistic instruction to a beleaguered Jewish community in the first few centuries of the Common Era. Such heavenly voices are said to have emerged only after the Holy Spirit had “departed” from Israel. This event was reckoned to have

\footnotetext{
${ }^{1}$ It is variously translated; "heavenly voice," "voice from heaven,” or "heavenly echo.” Occasionally, I will use one of these epithets. More often I will simply use the phrase "bat kol."

${ }^{2}$ See Arthur Mamorstein's list in Bernard Grossfeld, The Two Targums of Esther (Collegeville, MN: The Liturgical Press, 1991), 18.
} 
occurred with the destruction of both the First and Second Temples, correspondingly, or with the death of the last prophets, Haggai, Zechariah, and Malachi sometime during the sixth century BCE. With the final destruction of the Temple by Roman legions in $70 \mathrm{CE}$, the rabbis articulated God's ongoing and vibrant communication through the mysterious “daughter of a voice.”

The bat kol is traditionally understood as constituting part of the Haggadic (i.e., lore) stratum of rabbinical literature. ${ }^{3}$ Haggadah is typically defined as everything that is not Halachic or legal and is believed to comprise one fourth of the overall Talmudic corpus with the remaining three fourths constituting Halacha or "law". ${ }^{4}$ A certain Midrash or homiletical exegesis ${ }^{5}$ expresses the value of Haggadah as follows: "If you desire to know Him by whose utterance the World came into being, study the Haggadah, for through it you will discern Him who by His utterances called the World into being.” The writer of this Midrash understood Haggadah as a conducive mean in ascertaining the workings of God. Thus, Haggadah is construed as illuminating and directing the mind

\footnotetext{
${ }^{3}$ Haggadah is traditionally defined as everything that is not "Halachic," that is not legal. Both terms, however, are richly nuanced.

${ }^{4}$ See Ernest Trattner, Understanding the Talmud (New York: Thomas Nelson, 1955), 47.

${ }^{5}$ Howard Schwartz defines it as a method which, "searches for hints and explanations of the biblical text to resolve apparent contradictions and complete unfinished narratives. To accomplish this, it uses many techniques, such as examining the roots of words, drawing on earlier or later portions of the text (the chapters before and after are always considered relevant.), or using the purest kind of invention to resolve a knotty problem. Of course this invention is attributed to the Oral Torah, and therefore is regarded as legitimate.” Cf. Howard Schwartz, Tree of Souls: the Mythology of Judaism (Oxford: Oxford University Press, 2004), lxxvi.

${ }^{6}$ The Midrash is believed to be from ca. third century CE. See Sifre (Midrash on Numbers and Deuteronomy) on Deut. 11:22. Quoted by Z.H. Chajes, The Student's Guide through the Talmud (New York: Philipp Feldheim, 1960), 139.
} 
beyond required legal observance. It is no surprise then that key rabbinical figures such as Hillel the Elder and Rabbi Yohanan ben Zakkai, were considered expert Haggadists. ${ }^{7}$ Additionally, Maimonides, the prominent Medieval Jewish philosopher and legal codifier, noted how Haggadah was not meant to be interpreted literally, but studied in order to extract hidden inner meanings. ${ }^{8}$ Hence within the fanciful wrappings of Haggadah, are important truths meant to be unraveled, including the bat kol.

\section{Terms and Methodology}

The primary text consulted is the Babylonian Talmud, ${ }^{9}$ in addition to references from other important rabbinic works. The term Talmud ("study/learning") refers to two collections of writings (the Babylonian and the Jerusalem or Yerushalmi) which combine Mishnah and Gemara. The Mishnah is the work redacted by Judah ha-Nasi or Judah "The Prince" ca. 200 CE. It is comprised of protorabbinic ordinances and stories. The Gemara, which dates from about 200-525 CE, ${ }^{10}$ elucidates the Mishnah by providing Biblical justifications for said laws. In addition to expounding on the Mishnah, the Gemara, also includes Baraitot. These are extraneous traditions/stories not included in the final redaction of the Mishnah, and from which many stories surveyed in this thesis derive from. In keeping with the conventional titles for rabbinic teachers, those primarily

\footnotetext{
${ }^{7}$ See Raphael Patai, Gates to the Old City (Detroit: Wayne State University Press, 1981), xxiii.

${ }^{8}$ See Mishneh Torah (10, Intro.).

${ }^{9}$ I will abbreviate as "Bavli." When citing I will employ the following abbreviations: "B." stands for Babylonian Talmud, “J.” Yerushalmi (Jerusalem), “T.” Tosefta, and “M.” Mishnah.

${ }^{10}$ See Michael Chernick, ed., Essential Papers on the Talmud (New York: New York University Press), 477.
} 
from the land of Israel ${ }^{11}$ from ca. 30 BCE to 220 CE are referred herein as Tannaim. Teachers from 220 to 525 CE, both from the land of Israel and from Babylonia, are referred to as Amoraim. ${ }^{12}$ In addition, I will make occasionally specify to which corresponding generation a given sage is associated with (e.g., $1^{\text {st }}$ generation Tannaim 70-90 CE, $1^{\text {st }}$ generation Amoraim 230-250 CE, etc.).

In a few places I convey words and or sentences in Hebrew, Aramaic, or Greek in addition to a translation. These segments are meant to enhance the reader's appreciation of the discussion of any given text. Translations other than mine are noted accordingly. The primary source is in Mishnaic (or Rabbinic) Hebrew and Aramaic. However, I have primarily utilized the Schottenstein edition of the Babylonian Talmud by Mesorah Publications for translations including the text in both its original language in addition to a straightforward English translation. ${ }^{13}$ Moreover, at times I have employed other scholarly resources like Marcus Jastrow’s dictionary of rabbinic terms. ${ }^{14}$ Bible translations are primarily taken from the New King James Version, unless otherwise noted.

Commentary is provided for each example noting details such as context, characters, and narrative structure, in addition to references from parallel versions and or

\footnotetext{
${ }^{11}$ I will also employ the term "Jewish Palestine” to refer to the same geographical region.

${ }^{12}$ Chernick, Essential Papers, 478.

${ }^{13}$ Other Talmudim are sometimes referenced.

${ }^{14}$ Marcus Jastrow, A Dictionary of the Targumim, the Talmud Babli and Yerushalmi, and the Midrashic Literature (London: Trübner, 1886).
} 
supplemental stories from sources such as the Mishnah, Tosefta, Yerushalmi (Jerusalem) Talmud, et al. These synoptic readings enable scholars to better interpret the material in order to explicate issues related to redactional and historical topics. I will occasionally allude to such perspectives in order to enhance my own analysis.

My methodology consists mainly of both philological and literary approaches. The Philological aspect seeks to analyze pertinent information conveyed in the language of any given story. The words attributed to the bat kol, for instance, form the foundation for category titles and their subsequent interpretations. Similarly, observing recurring expressions in various stories is identified and analyzed. My hermeneutical approach,

furthermore, is also informed by the literary genre of rabbinic stories in general. I consult various scholars on Haggadah such as Z.H. Chajes, Raphael Patai, and Geoffrey H. Hartman and Sanford Budick, et al. These secondary sources provide commentary, explanations, and insights related to the multifaceted Haggadah. This in turn facilitates insightful interpretations of the bat kol within a more concrete literary context. While Talmudic literature is known not as a historical work in the modern sense of the word, it is nonetheless interspersed with historical details within its discursive fabric. As a result, I also include scholarly commentaries on historical periods and characters alluded to in such texts.

\section{Chapter Overviews}

\section{A. Literature Review:}

The first chapter consists of a cursory overview of about twenty, Jewish and Christian, scholarly works on the bat kol. The dates of publication are from the last one 
hundred years, roughly speaking. This review is by no means exhaustive, with more time I would integrate and synthesize more sources. Instead, this chapter is meant to provide the reader with an adequate understanding of the main views on the bat kol, as the rabbis left no explanation for this phenomenon. Therefore, to a degree, scholars have had to infer as to its nature and function via the stories written by the sages. Several scholars purport that the word bat is meant to convey an "echo." Others, such as Ludwig Blau and Kauffmann Kohler suggest it means a "reverberation" or "hum" and define the bat kol as a disembodied voice often synonymous with God and or the Holy Spirit. ${ }^{15}$

Scholars such as John Nicholson and S. Louis note that this voice may have possibly existed only in the individual's mind. While a prevalent definition is its function as a harbinger of God's will. Alexander Guttmann and Arthur Marmorstein discern in the usage of the bat kol possibly polemical motives. And Saul Lieberman observes how it was employed in oracular fashion, which is to say to a medium of divine consultation through chance utterances.

Nevertheless, this thesis represents a focused effort to analyze the role of the bat kol as a literary theme in the Bavli. The works presented in the review include subsections of chapters pertaining either to prophecy, Holy Spirit, or Haggadah, as well as encyclopedic articles. In his article, S. Louis, proposed several categories by which to catalogue the many occurrences of the bat kol; that format has been employed in this thesis as well. Admittedly, the categories selected in this thesis were chosen because they

\footnotetext{
${ }^{15}$ See Isidore Singer and Cyrus Adler, Jewish Encyclopedia (New York: Funk \& Wagnalls Co., 1901), "bat kol.”
} 
were the author's preference for best capturing the essence of the "voice from heaven." Other scholars have proposed different categories such as embellishing Biblical narratives, and appearing during supernatural events.

\section{B. Origins:}

The following chapter is devoted to exploring cognates within various bodies of literature in order to point to plausible relationships. The chosen bodies of literature are Biblical, Apocalyptic, and Hellenistic. I do not set out to make any definitive claims but rather propose that these sources may have influenced the rabbis in their description of the bat kol. This chapter delves into the topic on an introductory and comparative level. Furthermore, I briefly address the subject of "cessation of prophecy" according to a rabbinic dictum. Both rabbinic and contemporary sources such as those found at Qumran, depict prophetic activity as ongoing and even desirable. The subject was more nuanced both for the rabbinic fold and for other sects of the Second Temple period.

In one specific Biblical episode in which king Nebuchadnezzar is addressed spontaneously from a voice from heaven, I will present details paralleling its use with a rabbinic anecdote and suggest that the rabbinic story is reliant on the Biblical account. Both stories are reflective of one another in terms of manifestation, words, and the main character of the story. I will also draw in other parallels such as the intervening "voice from heaven” in Isaac's binding and Ishmael and Hagar's deliverance. Therefore, I propose it is highly plausible that the bat kol was greatly informed by the "voices from heaven” found throughout Biblical literature. This is all the more likely considering how 
well acquainted the rabbis were with the language and content of the Biblical milieu as reflected in their Midrashic compilations.

Closer in chronology is the genre of apocalyptic literature. This section presents an overview of 2 (Syriac) Baruch, 3 (Greek) Baruch, and 4 Ezra. The main thesis of this subsection is that heavenly voices played a central role in such literature, typically as beings directing, so to speak, the activities in the heavenly realm during an individual's heavenly ascent. My research is complimented with numerous scholars, such as John Collins and David Aune, who expound on the nature of apocalypticism, Biblical prophecy, and rabbinic literature. Though some scholars have denied the relationship between apocalyptic and rabbinic writings other scholars have suggested a different reality. I affirm the latter view and present a few pieces of evidence why a relationship between the two is actually conceivable. These sources contain numerous instances of heavenly voices in what are typically scenes of ascent into heaven. They also share common themes in rabbinic writings such as reward and punishment in the afterlife, and the problem of evil.

An insufficient amount of data is presented concerning Hellenistic examples that draw comparison with the bat kol, particularly in their description of heavenly voices echoing from Greek temples. Similar events are also attested by the Roman-Jewish historian, Flavius Josephus, in his work entitled Antiquities as well as in both the Jerusalem and Babylonian Talmudim. ${ }^{16}$ Moreover, I include Josephus' description of

\footnotetext{
${ }^{16}$ Josephus (Antq. XIII 10.3); J. Sotah 24b; B. Sotah 33a.
} 
Jesus son of Ananias' oracle of doom which references “a voice.” In sum, many works exhibit heavenly voices sounding off at various times and places. My understanding is that vestiges of the heavenly voices from Biblical and Apocalyptic works are most palpable in the stories of the bat kol. I have merely sought to introduce these ancient works without a proper in-depth look at these sources. Therefore, the body of Greek writings and Josephus should be analyzed and explored more substantially. At this time, I am unable to sufficiently elaborate on these last parts of the Origins chapter.

\section{Categories:}

This chapter lays out about ten interpretive, didactic, and homiletical stories, each situated within a specific category. I did not expound on all the stories contained within the Babylonian corpus, about sixty cases (not including repeats), as that would require more time than currently available. I preface my analysis with a short introduction into the world of the Talmud and Haggadah as important background information for the chapter. The categories are: announcing someone's entry into "the world to come", praise towards individuals, words of rebuke, and matters pertaining to Halacha (law). I have further suggested that a group of stories fall in neither of the aforementioned categories. I designated this additional category "miscellaneous." The category of the "world to come" recounts the martyrdom story of the second century sage, Rabbi Akiva; a highly-didactic account. I then comment on Rabban Gamaliel's close encounter with martyrdom. ${ }^{17}$ The Roman officer who spared the sages' life acquired life in the "world to come;" this was publicly announced the by the bat kol.

\footnotetext{
17 "Rabban” was a title given to Patriarchs (leaders) of the Sanhedrin.
} 
I subsequently proceed to draw the reader's attention to individuals signaled out by the bat kol, these include Hillel the Elder, Samuel the Small. The chapter on Halacha provides an analysis of the well-known legal deadlock between the two, first century schools of Shammai and Hillel. Also included in this chapter is the showdown between R. Eliezer ben Hyrcanus and the rest of sages, in what is known as the incident of the oven of “Aknai.” I draw from Jeffrey Rubenstein's analysis of this story in his book Talmudic Stories, in which he insightfully interprets the incident within its legal context. ${ }^{18}$ The miscellaneous section overviews stories such as the one purporting that a bat kol went forth from the Jerusalem Temple announcing to Hasmonean ruler, John Hyrcanus, that his sons had won a military victory.

Each story includes a brief analysis, as well as references to parallel or supplementary information. These groupings have been previously noted and used by other scholars of rabbinics and Haggadah. Similarly, I affirm the use of these labels in interpreting the role of the bat kol in these stories while providing my own commentary and examples. In my estimation, the most marked categories are announcing someone's entry into the "world to come" and praising individuals for their piety and or rebuking them for their wickedness. Each story seems to contain a moral of sorts applicable to that time period, including those retrojected on to Biblical characters.

The final chapter will be a recapitulation of the findings from the chapters along with additional commentary. Furthermore, I identify several areas left unaddressed that

\footnotetext{
${ }^{18}$ See Jeffrey Rubenstein, Talmudic Stories: Narrative Art, Composition, and Culture (Baltimore: The John Hopkins University Press, 1999), 34-63.
} 
draw my attention for potential future work. As a personal aside, my introduction to the bat kol was while reading Daniel Boyarin's book Dying for God: Martyrdom and the Making of Christianity and Judaism where Boyarin makes some intriguing perspectives on the nature and development of martyrdom among Jews and early Christians in antiquity. Boyarin includes the incident of "Aknai" in which the bat kol (or "voice from heaven”) allegedly intervened in an intense legal debate only to be silenced. Such audacity seemed remarkable! Consequently, I began to develop an appreciation for Jewish stories, their language, depth, and subtleties. It is my hope that through this preliminary study, the reader might likewise become engaged with the subject of Jewish stories. The historical setting of the sages is one of life, loss, law, and lore; it is key for elucidating the tales of the bat kol. After all, it is through their voice that we know of the “daughter of a voice.” 


\section{LITERATURE REVIEW}

\section{Introduction}

It is fitting to present a literature review of some of the most pertinent studies on the bat kol with a special focus on its function. Since the rabbis themselves left no explanation for the meaning of this enigmatic term, it is not surprising that scholars have not been unanimous in identifying the function and or purpose of the bat kol. However, one over-arching view is that the "voice from heaven" was employed as a vehicle which delivered news of divine judgment, which in this way resembled the prophetic nature of the Biblical prophets. Because of the fact that there are parallels to the bat kol found in early Christian writings, Christian scholarship will also comprise part of this review. ${ }^{19}$

I have chosen to present the sources in chronological order of dates of publication, while highlighting their main contributions in terms of role. This thesis should ultimately be viewed as a continuation of the prior research conducted in the general field of divine manifestations in Judaism of classic-late antiquity. I seek both to draw from and build on the work of previous scholars while positioning myself to offer potentially new perspective(s) on this intriguing portent, all within a social and historical framework. In addition, I have sought to minimize repetition of data among the sources and for that reason some sections may be shorter than others. Additionally, insights unique to a scholar are also included in this review.

\footnotetext{
${ }^{19}$ E.g. Jesus’ immersion: Matthew 3:13-17, Mark 1:9-11, Luke 3:21-23.
} 


\section{Cyclopedia of Biblical Literature (article by John Nicholson, 1858)}

A brief and yet substantial article was published by John Nicholson, appearing in the Cyclopedia of Biblical Literature, in the late-nineteenth century. ${ }^{20}$ He cites several Christian Hebraists who wrote in Latin, German, and English. ${ }^{21}$ Nicholson identifies the bat $\mathrm{kol}$ as the fourth grade of revelation, noting that it was the quintessential form of prophecy during (and after) the period of the Second Temple. ${ }^{22}$ In addition, he alludes to a highly-debated aspect of the bat kol, which is whether or not individuals who claimed to hear a bat kol actually heard an audible voice (communication) or a faint sound like that of an echo. Some interpreters posit that it may have very well represented the innerthoughts of individuals. Nicholson does not state whether or not he considers the bat kol to be purely psychological. Maimonides, for example, the great Medieval Jewish philosopher and legalist, was of such opinion. He espoused that man's vivid imagination led him to believe he heard something outside of himself. ${ }^{23}$ Also interesting, is the

\footnotetext{
${ }^{20}$ Ed. John Kitto, Cyclopedia of Biblical Literature, vol. I (New York: Ivison \& Phinney, 1858), 304-305.

${ }^{21}$ The following are additional sources in Latin and German (currently, I am not learned in these languages): Latin: Vitringa, Observationes Sacrae (Franequerae: Bleck, 1708). Adrien Reland et al., Antiquates Sacrae Veterum Hebraeorum (Traiecti ad Rhenum: Ex Libraria Ioannis Broedelet, 1741), 134135. Balthaser Scheidt, Novum Testamentum ex Talmude (Lipsiæ: apud hær. J.F. Braunii, 1736), 350ff. German: Johannes Lindblom, Gesichte und Offenbarungen. Vorstellungen von Göttlichen Weisungen und Übernatürlichen Erscheinungen im Ältesten Christentum (Lund: Gleerup, 1968), 17, n.2. Peter Kuhn, Offenbarung Stimmen im Antiken Judentum: Untersuchungen zur Bat Qol und Verwandeten Phänomen (Mohr Siebeck, 1989). Georg Herlitz, Georg and Bruno Kirschner, Jüdisches Lexikon; Ein Enzyklopädisches Handbuch des Jüdischen Wissens in Vier Bänden Mit Über 2000 Illustrationen, Beilagen, Karten und Tabellen (Berlin: Jüdischer Verlag, 1927).

${ }^{22}$ Kitto, Cyclopedia, 304.

${ }^{23}$ Kitto, Cyclopedia, 304.
} 
reference to Christian scholars, like John Lightfoot, ${ }^{24}$ who explained away the bat kol of rabbinic texts as either "fables” or "devices of the devil," perhaps an effort to protect the veracity of cognates in the Gospels? ${ }^{25}$ While Nicholson does not extensively explain what he considers to be the function of the bat kol, he does put forth the basic view that it was considered to be a lower grade of prophecy ${ }^{26}$ in the rabbis’ understanding.

\section{III. “Ancient Traditions of Supernatural Voices (Bath-Kol)” (article by S. Louis,} 1893)

Another late $19^{\text {th }}$ century work was produced by S. Louis in the reference work, Transactions of the Society of Biblical Archaeology. ${ }^{27}$ His attempt to suggest various categories for the appearances of bat kol within the Talmudic corpus seems unique to his work. ${ }^{28}$ Indeed, his article presents a model for the approach I have adopted in organizing and labeling my own data. One of those functions (or categories) is the role of influencing Halachic (legal) issues. ${ }^{29}$ Some of his other categories include: priests receiving news of military victories while serving in the Temple, instances of

\footnotetext{
${ }^{24}$ See John Lightfoot, Horce Hebraica et Talmudica; Hebrew and Talmudical exercitations upon the Gospels, the Acts, some chapters of St. Paul's Epistle to the Romans, and the First epistle to the Corinthians (Oxford: University Press, 1859), 81-83. See also Matthew 3:17.

${ }^{25}$ See Kitto, Cyclopedia, 305.

${ }^{26}$ Actually the fourth grade, cf. Kitto, Cyclopedia, 304.

${ }^{27}$ Society of Biblical Archaeology, Transactions of the Society of Biblical Archaeology vol. IX, (London, 1893), 182-194.

${ }^{28}$ The end of the article contains a list of passages in both the Bavli (Babylonian) and Yerushalmi (Jerusalem) Talmudim (plural of Talmud); Society, Transactions, 194.

${ }^{29}$ See August Friedrich Gfröer, Jahrhundert des Heils (Schweizerhart's Verlagshandlung, 1883), 175. Louis also comments that this function resembles a later use employed by councils of the Catholic Church in judging heresies.
} 
commending individuals in moments of martyrdom (either before and or after their deaths), its use in propagating popular ideas, and its interactions with Biblical characters.

Unlike Greek oracles which were solicited, Louis notes that the bat kol is steadfastly impromptu, that is it appears spontaneously, ${ }^{30}$ and in some cases in couples. ${ }^{31}$ Similarly to Maimonides, he infers that what is being attributed to the bat kol should really be ascribed to the inner thoughts of the people. ${ }^{32}$ In identifying several purposes for the bat kol, Louis displays what I believe to be a well-rounded approach, which was noteworthy since at the time few Christian scholars devoted much research to traditional Jewish topics. The purpose of the divine voice seems to vary from story to story, though common motifs can be discerned.

\section{From Letter to Spirit by Edwin A. Abbott (1903)}

Christian scholar Edwin A. Abbott produced a formidable work in which he employed a comparative approach between rabbinic writings and Christian texts on this subject. He notes that the phrase bat kol does not appear in the Bible; however, he does suggest the phrase "voice of the LORD" 33 is relevant to the "daughter of a voice" ${ }^{34}$ in

\footnotetext{
${ }^{30}$ Society, Transactions, 191.

${ }^{31}$ The Gospel of Matthew contains two passages where the voice from heaven reiterates what it had previously announced; cf. Matthew 3:17 and 17:5.

${ }^{32}$ And I would include the redactors of the texts; Society, Transactions, 185.

${ }^{33}$ Which first appears in the Genesis 3:8, the account of Adam and Eve when they "heard the sound of the LORD in the garden...”

${ }^{34}$ The first time the word is used in the Bible appears in Genesis 3:8, where it is usually translated "the voice of the LORD." Abbott takes this example to be a precedent for the construct: "the voice of the LORD,” in matters of judgment; cf. Edwin Abbot, From Letter to Spirit, (London: A. and C. Black, 1903), 141.
} 
terms of revelation. He notes two parallels in non-rabbinic literature with the bat kol. One of these relates to a bat kol informing John Hyrcanus ${ }^{35}$ while he was serving in the Temple, that his young sons had just won a military victory. ${ }^{36}$ The other similar dynamic is an account of Herodotus, when Greeks at Mycale received "word” of the victory of their compatriots while spurring them on to fight. ${ }^{37}$

Part of the great worth of this book is his detailed overview of Jewish sources. Beginning with the Mishnah and ending with the Midrashim, he highlights important places where the term bat kol appears. One such example comes from the Mishnah where we read that a woman is allowed to remarry on account of a bat kol declaring that "so and so, the husband of so and so" has died. ${ }^{38}$ Elsewhere we find the rabbis asserting that forty days prior to the formation of an embryo, a bat kol goes forth and announces "the daughter of so and so, for so and so, this particular house for so and so, and this particular field for so and so.”39

The point seems to be that marriages were believed to be prearranged in heaven, consequently the bat kol enjoyed the status as a legitimate witness in communicating the death of a husband. Finally, he notes the phrase appears eight times in Targum Pseudo Jonathan, usually beginning with the phrase "from heaven.” The first four occur in the

\footnotetext{
35 John Hyrcanus was a Maccabean ruler (ca. 134-104 BCE).

${ }^{36}$ Abbot, From Letter, 141.

${ }^{37}$ Following Homer's thought, a "pheme” or winged goddess, flew to the camp with the sudden news; cf. Herod. IX, 100-101. Quoted by Abbott, From Letter, 142.

${ }^{38}$ B. Yev. 16:6.

${ }^{39}$ See B. Sotah 2a, Sanhedrin 22a.
} 
Torah (Gen. 38:26; Num. 21:6; Deut. 28:15, 34:5) while the remaining four examples are found in the Targumim of, Song of Solomon (2:14; 4:1), Esther (5:14), and Lamentations (3:38).

\section{Jewish Encyclopedia (article by Ludwig Blau and Kauffmann Kohler, 1906)}

One of the most comprehensive reference works is Ludwig Blau and Kauffmann Kohler's article from the Jewish Encyclopedia. Essentially, the article views the bat kol as a harbinger of God's will and judgment, a lesser gift than prophecy but not a less significant mode of prophecy. According to B. Sotah 33a the bat kol was understood to be the voices of angels, particularly Gabriel, who knows all the world's languages. ${ }^{40}$ Contrary to opinions that uphold that the term is better understood to mean an "echo," the authors consider this an unfounded interpretation since the Hebrew word habarah, is sometimes used to denote reverberating sounds such as an echo. ${ }^{41}$ Rather, they characterize the phrase as a voice heard where no one is to be found, in addition to the extraordinary quality of the sound being heard. ${ }^{42}$ This trait of divine revelation is found repeatedly throughout the Hebrew Bible such as when the prophet Ezekiel heard the voice of God speaking to him ${ }^{43}$, Elijah discerning God's still small voice ${ }^{44}$, and the

\footnotetext{
${ }^{40}$ The sages believed that there were seventy languages in the world.

${ }^{41}$ See B. Yoma 19b. Marcus Jastrow, Dictionary of Targumim and Midrashic Literature (New York: Pardes, 1950), 330.

${ }^{42}$ The article cites the highly-relevant passage of God's revelation at Sinai, where Moses says to the people "you heard the voice of the words, but saw no similitude; you only heard a voice” (Deut. 4:12).

${ }^{43}$ Ezekiel 1:28.

${ }^{44} 1$ Kings 19:12-13.
} 
prophet's descriptions of God's voice ringing forth from the heights of Jerusalem. ${ }^{45}$

They also observe that a bat kol typically conveys negative tidings versus instances of positive news where God himself communicates the message without the use of a "voice from heaven." 46

The article also comments on certain functions such as embellishing Biblical stories, appearing during supernatural events, and in moments of death or martyrdom. They also consider it to be divine in nature, noting that it is used interchangeably in rabbinic writings with God and the Holy Spirit, including the fact that sometimes God speaks via the bat kol in the first-person. ${ }^{47}$ According to the authors, a later-apocalyptic view upheld that its main function was to lead celestial beings in the adulation of the most-high. ${ }^{48}$ Similarly, another view admonishes the Shechinah ${ }^{49}$ to flee upon hearing a dissonant synagogue. ${ }^{50}$

\footnotetext{
${ }^{45}$ See Jer. 25:30, Joel 4:16-17, and Amos 1:2.

${ }^{46}$ See Targum Lamentations 3:38, found in Kohler and Blau's article, "Bat Kol”; cf. Isidore Singer and Cyrus Adler, Jewish Encyclopedia (New York: Funk \& Wagnalls Co., 1901), 588-592.

${ }^{47}$ Isidore and Adler, Jewish Encyclopedia, 589.

${ }^{48}$ See Isidore and Adler, Jewish Encyclopedia, 592. Compare with the book of Revelation (19:1) where a loud voice from heaven leads a song of praise.

${ }^{49}$ George Foot Moore defines it as "a metonymy for God;” also understood as God's abiding presence; cf. George Foot Moore, Judaism in the First Centuries of the Christian Era the Age of the Tannaim vol. I (New York: Shocken Books, 1927), 434-435.

${ }^{50}$ See Canticles Rabbah 8:14.
} 


\section{Judaism in the First Centuries of the Christian Era by George F. Moore (1927)}

George Foot Moore, published a multi-volume work of Judaism during the first centuries of Christianity. He essentially defined bat kol as a, "resonance, echo."51 Moreover, he wrote, "In the use we are discussing it is an articulate and intelligible sound proceeding from an invisible source, generally from the sky, or out of the adytum of the Temple."52 In Moore's view, the most important example of the bat kol is the story of when the sages were gathered at Yavneh in order to settle a prolonged dispute between the two schools of Hillel and Shammai. The voice from heaven affirmed that both rulings were the words of God, but that the school of Hillel should be followed. He also surmises why the epithet bat kol $^{53}$ is used rather than the more traditional, kol (voice), when referring to speech believed to originate from heaven: namely, it was to avoid the possibility for individuals to claim that they heard God's voice directly. ${ }^{54}$ This view complements the sage's statement concerning the departure of the Holy Spirit after the death of the last prophets. Undoubtedly, the sages appropriated the role as the custodians of God’s revelation, the ones who both discover and propagate God’s will.

\footnotetext{
${ }^{51}$ Moore, Judaism, vol. II, 50 (of index).

${ }^{52}$ Moore, Judaism, vol. I, 422.

${ }^{53}$ See index of Moore, Judaism, vol. I, 127. Similarly to what other scholars have opined, Moore considers this qualifying term to denote a secondary or derivative sound. Such writes the Tosafot on Sanhedrin 11a. For the idea of a faint sound he references 1 Kings 19:12, where Elijah discerns God's presence through a small voice.

${ }^{54}$ Moore, Judaism, vol. I, 127. One of the texts he cites in support of this view is from Exodus Rabbah 29, 9, where the writer affirms that God's voice has no echo (bat) unlike men for the purposes of not misattributing his sovereign power to another being.
} 


\section{The Significance of Miracles in Talmudic Judaism by Alexander Guttmann} (1947)

Alexander Guttmann, in The Significance of Miracles in Talmudic Judaism, made intriguing remarks concerning the bat kol. In particular, his views are concerned with the possible range of meanings that may have been ascribed by the rabbis in light of nascent, first-century Christianity. He ascribes to "the voice" a Halachic function. Thus, in the prolonged stalemate between the two schools of Hillel and Shammai, ${ }^{55}$ the bat kol chimed in to endorse the school of Hillel and the sages did not object. ${ }^{56}$ In addition, the rabbis accepted the bat kol's authority if it announced that a man had died allowing his wife to subsequently remarry; the announcement stood even though the body of the deceased was unfound. ${ }^{57}$

However, in another (and Guttmann argues historically later) episode the intervention of the bat kol on behalf of R.(rabbi) Eliezer ben Hyrcanus was of no avail in persuading his peers that the law should be in accordance with his understanding. Rather, R. Joshua (who was R. Eliezer's debate partner) adamantly opposed this phenomenon stating that they do not pay heed to voices from heaven, essentially arguing that God himself had delegated such authority to the sages. ${ }^{58}$ Guttmann interprets these two very

\footnotetext{
55 They were two major schools of law from the first century BCE to the first century CE, who often debated points of jurisprudence with one another as found in the Talmud.

${ }^{56}$ He dates this event to the first-generation Tannaim (70-90 CE); Alexander Guttmann, The Significance of Miracles in Talmudic Judaism (Cincinnati: Hebrew Union College Annual, 1947), 384.

${ }^{57}$ See Mishnah Yev. 16:6, Tosefta 14:7, J. Nazikim 51 b.

${ }^{58}$ Guttmann notes that in the case of Hillel and Shammai the bat kol followed the majority opinion while in the incident of the “oven of Aknai” (i.e. R. Eliezer's excommunication) it supported the minority opinion.
} 
opposite results as historical reactions to burgeoning early Christianity. Hence, the controversy surrounding the two Pharisaical schools was at a time when Christianity was not perceived as a viable threat to the Judaism of the Pharisees/rabbis. However, Guttmann posits that after $90 \mathrm{CE}^{59}$ Christianity's claims of revelation were known to the sages and that this ruling may be interpreted as an attempt of the sages to stifle any influence reminiscent of Christianity upon their movement. ${ }^{60}$ Thus, he proposes that the quality of the bat kol devolved from a miraculous sign to a voice bursting out from amongst a crowd. ${ }^{61}$

\section{Studies in Jewish Theology by Arthur Marmorstein (1950)}

Arthur Marmorstein, wrote on the "voice from heaven” in his work, Studies in Jewish Theology. He understands the "voice" as an integral part of the legendary (i.e., Haggadic) material of rabbinic writings that typically cite Biblical phrases when it appears. $^{62}$ For Marmorstein, the Haggadists, usually project conditions of their own time in to the Biblical era, thus what the "voices from heaven” are to have declared in Biblical

However, he notes that it is peculiar that if it was accepted as evidence before, and later when endorsing an individual, it was an offense to the authorities; cf. Guttmann, The Significance, 384.

\footnotetext{
${ }^{59}$ Around this date is when scholars believe the rabbis convened at Yavneh. Avram Topper wrote that some posit that the rabbis ejected all non-rabbinic Jews from the fold at this meeting; cf. Adam H. Becker and Annette Yoshiko Reed, The Ways That Never Parted: Jews and Christians in Late Antiquity and the Early Middle Ages (Tübingen: Mohr Siebeck, 2003), 183. S.D. Cohen suggested that dissenters were absorbed through a more amicable process of "agreeing to disagree;” cf. S.D. Cohen, “The Significance of Yavneh: Pharisees, Rabbis, and the End of Jewish Sectarianism” Hebrew Union College Annual, 55 (1984), 28, n.2.

${ }^{60}$ See Guttmann, The Significance, 384.

${ }^{61}$ See Guttmann, The Significance, 386.

62 See Arthur Marmorstein, Studies in Jewish Theology (London: Oxford University Press, 1950), 136.
} 
stories, serves an important didactic purpose for Jews in antiquity. ${ }^{63}$ Furthermore, he underscores the importance attributed to the bat kol by the fact that Babylonian teachers divided their material into periods before and after its manifestations. ${ }^{64}$ As a result we are afforded a multifaceted view of Judaism as one not solely embracing legal acuity and piety but also mystical manifestations of the divine as integral to religious life.

Therefore, Marmorstein interprets its function as uniting two important aspects of Judaism: its law-orientated emphases and God’s immanent presence.

Marmorstein makes two general comments in regards to the bat kol: it intervened in learned subjects or practical matters, not just to predict future events or statuses, and there were some who deemed its revelations as invalid and non-authoritative. ${ }^{65}$ One final observation he puts forth is its usage as an agent of comfort for martyrs. Often these stories include the reassurance that they or the person who just died, had merited entry into eternal life (i.e., “world to come”). ${ }^{66}$

\section{Hellenism in Jewish Palestine by Saul Lieberman (1950)}

The great Talmudist Saul Lieberman wrote concerning the bat kol that in the simplest sense it could be understood as an echo or reverberating sound. ${ }^{67}$ Furthermore

\footnotetext{
63 See Marmorstein, Studies, 140.

${ }^{64}$ See B. Yev. 14a; B. Eruvin 6b, 13b; B. Pesachim 114a; B. Ber. 52a, B. Chullin 44a; cf. Marmorstein, Studies, 136.

${ }^{65}$ Marmorstein, Studies, 138. R. Joshua is the prime example. The bat kol was not limited to academies and corporate gatherings of the sages, but also appeared to individuals.

${ }^{66}$ Marmorstein, Studies, 143. He comments, “As these legends are met with in every century of the old rabbinic period, in Babylon as well as in Palestine, it must be admitted that the conceptions underlying them were at that time deeply rooted in the life of the people;” cf. Marmorstein, Studies, 178.

${ }^{67}$ Saul Lieberman, Hellenism in Jewish Palestine (New York: Jewish Theological Seminary, 1950), 194199.
} 
he understands the phrase, "they were wont to make use of the Holy Spirit or bat kol" as being awkward in Hebrew thus perhaps indicating it was translated from the Greek language. ${ }^{68}$ He suggested that the phrase is better rendered, "to consult the bat kol, to consult the Holy Spirit.”69 Prominent forms of consultation included listening for chance words that would provide some kind of insight, answer, or direction into a specific matter ${ }^{70}$ in addition to words of Scripture spoken by children. ${ }^{71}$ Lieberman demonstrates how these forms of "divination" were not unique to the rabbis but were also used by the Egyptians and Greeks. ${ }^{72}$ However, where the rabbis differed, was in their emphasis on the unequivocal and candid nature of prophecy. ${ }^{73}$ In other words, they expected communication from God to be simple and straightforward. ${ }^{74}$ Lieberman has impressively stressed a point that others have not: the bat kol functioned as a type of divination that was in vogue in various cultures. Furthermore, he notes that the bat kol's

\footnotetext{
${ }^{68}$ Lieberman, Hellenism, 195. The phrase occurs in B. Megillah 32a; Genesis Rabbah 37. 7, 349.

${ }^{69}$ Lieberman, Hellenism, 195.

${ }^{70}$ Lieberman, Hellenism, 195. One example is found in the Babylonian Talmud, tractate Megillah 32a, where we read "When do we know one may consult a bat kol? Because it is said (Isaiah 30:21): and thine ears shall hear a word behind thee saying..."

${ }^{71}$ Lieberman, Hellenism, 195. Examples include B. Hagigah 15a ff; Gittin 68a; Esther Rabbah (to Esther 3:9). Lieberman writes that this form of divination was ascribed to the Roman emperor Nero, cf. B. Gittin $56 \mathrm{a}$.

${ }^{72}$ He thinks these were not prohibited by the rabbis but were considered a type of sign (אות) from heaven, a form of prophecy, cf. Lieberman, Hellenism, 195-196.

${ }^{73}$ Lieberman, Hellenism, 199.

${ }^{74}$ His support text comes from Esther Rabbah to Esther 3:14 where it is written that the Jews, "were to be ready against that day to avenge themselves of their enemies;" cf. Lieberman, Hellenism, 198-199.
} 
oracular function is more visible in post-Tannaitic literature. ${ }^{75}$ I think his view insightfully addresses a clear segment of instances that are a minority in rabbinic writings.

\section{The Rabbinic Mind by Max Kadushin (1952)}

In The Rabbinic Mind, Max Kiddushin devotes a small but important section to the topic of bat kol in the chapter "Normal Mysticism." He notes that the commentary of certain $12^{\text {th }}$ and $13^{\text {th }}$ century Talmudic scholars, known as the Tosafot, explain the word bat as conveying the idea of an echo deriving from a separate sound assumed to be of heavenly origin. ${ }^{76}$ Furthermore, he reads the bat kol as an experience devoid of God thus different from the activity of Biblical prophets, who experienced either direct visitations from Ruach ha-Kodesh (Holy Spirit) or Gilluy Shechinah (Revelation of God's glory). Thus, according to Kiddushin, the rabbis understood the bat kol as consisting of a completely different phenomena from previous prophetic norms of revelation. ${ }^{77}$ While it is true that evidence suggests it was viewed distinct from previous manifestations of God, it was not completely unrelated either.

\footnotetext{
75 See Azzan Israel, Scripture and Tradition: Rabbi Akiva and the Triumph of Midrash (Philadelphia: University of Pennsylvania Press, 2015), 174.

${ }^{76}$ Max Kadushin, The Rabbinic Mind (New York: Bloch Publisher, 1972), 261-262.

77 This is why Kiddushin says it lacked authority at times to promulgate legal decisions. It was not an experience in which the Holy Spirit manifested itself to the prophet giving credence to the prophecy.
} 


\section{Prophetic Inspiration after the Prophets by Abraham J. Heschel (1966)}

Abraham Joshua Heschel, also wrote on the subject of bat kol, though not extensively. The first pages of Prophetic Inspiration after the Prophets, immediately address the topic noting that it was "a kind of prophecy."78 One noteworthy detail is his differentiating of revelation to the prophets and revelation to the sages. The former was done primarily via "a voice” ( $\mathrm{kol})$ while the latter was achieved via the bat kol ("daughter of a voice”). ${ }^{79}$ He further comments that the bat kol during the Amoraic period, ${ }^{80}$ was understood to communicate messages from heaven in a natural manner. ${ }^{81}$

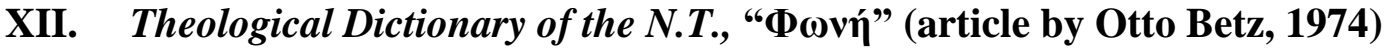

Otto Betz's article is a stellar reference-work due to the manner in which he historically and systematically reviews the usage of the Greek term $\varphi \omega v \eta$ ("sound" or “voice”) and its general Hebrew equivalent קול. This wide-ranging comparison among various literatures allows the reader to infer possible connections from source to source. Betz shows how Greek literature employed a variegated usage of the term ranging from the cries of animals to the instrument of divine fiat; some of the examples are reminiscent of the bat kol. ${ }^{82}$

\footnotetext{
${ }^{78}$ Abraham Joshua Heschel, Prophetic Inspiration after the Prophets: Maimonides and other Medieval Authorities, ed. Morris M. Faierstein (Hoboken: Ktav Pub., 1966), 2.

${ }^{79}$ Further, Heschel includes’ Rashi’s commentary on B. Sotah 33a, “The attribute which is appointed for this task knows the seventy languages, because it is prepared to transmit its message in whatever language is appropriate.” Cf. Heschel, Prophetic, 2.

${ }^{80}$ Ca. $220-400$ CE.

${ }^{81}$ See B. Megillah 32a. Heschel, Prophetic, 2.

${ }^{82}$ See Gerhard Kittel et al., Theological Dictionary of the New Testament (Grand Rapids: MI, Eerdmans, 1974), 278-279. Betz references a Greek text that speaks of "the voice" emanating from temples; See Ael.
} 
The Hebrew term for voice, kol (קור), has in the Hebrew Bible a range of meanings. It can function to describe various sorts of noises: thunder, roars, sound of steps, and battle cries. ${ }^{83}$ On a few occasions angels are said to be communicate via a kol, even anonymously at times. ${ }^{84}$ Yet it also takes on a very important and prophetic connotation. As Betz rightly observes, God is neither seen nor touched so to speak, ${ }^{85}$ yet the fact that He is heard is of utmost significance. ${ }^{86}$ God's speech may vary in form and output, like the roar of rushing waters ${ }^{87}$ or the small divine whisper heard by Elijah. ${ }^{88}$ Interestingly enough, God's speech is so potent that it is described as causing the earth to tremble. ${ }^{89}$ Later, obeying the "voice of the LORD" would become synonymous with upholding the ancient Mosaic covenant. ${ }^{90}$

Betz comments, “Ancient oriental, OT, and especially apocalyptic-visionary traditions are adopted here [in the bat kol] and developed and formalized under the

Aristotle. Or. 20, 22 (Keil). This concept is mirrored in the attested "voices from heaven" by Josephus and Talmudic literature (cf. Ant 13.10.3 §282; Tosefta Sotah 13:5; B. Sotah 33a). Also relevant to the bat kol is the Greek usage of the term to express a significant statement or declaration, see "the statement of Simonides,” in B.A.F. Hubbard, Plato’s Protagoras (Chicago: University of Chicago Press, 1984), 341.

${ }^{83}$ For examples of thunder see: Exodus 9:23, 29, 33; 19:16; for roars: Psalms 42:7, 93:3f; for sounds of steps: Gen. 3:8; 1 K. 14:6; 2 K. 6:32, and for the sound of a battle cry: 1 S. 4:6.

${ }^{84}$ See Isaiah 40:3, 6; Ez. 1:24-25, and Daniel 4:28.

${ }^{85}$ It is obvious that the Bible reports that individuals did see manifestations of God. Exodus 33:22-23 relates that God agreed to reveal (lit. "My latter parts") to Moses but not His face.

${ }^{86}$ Betz notes that in about 50 of some 560 instances God is the author of kol; Kittel et al., Theological, 282.

${ }^{87}$ See Ezekiel 43:2.

${ }^{88}$ See 1 Kings 19:12.

${ }^{89}$ See Psalm 18:7-15. The idea of the divine voice having a powerful echo plays into the idea of a heavenly echo or "daughter of a voice," which are the terms by which the bat kol is normally understood.

${ }^{90}$ See Deut. 4:30; 8:20; 13:5, 19; 15:5; 26:14. 
impress of the divine transcendence." ${ }^{91}$ He further comments that the bat kol should not be viewed as a continuation of God's revelation, as begun at Sinai or delivered to the Biblical prophets, since the rabbis espoused that the canon had closed. In addition, Betz notes that the bat kol does not establish a lasting relationship between God and man, unlike the Holy Spirit. Nor is it exclusive to the righteous; it descends upon Gentiles and the unrighteous. ${ }^{92}$ Betz, purports that it comprises part of the popular and legendary material known as Haggadah, normally resorted to for moral instruction.

\section{Essays in Jewish Thought by Nahum Glatzer (1978)}

Nahum Glatzer in Talmudic Interpretation of Prophecy, asserts that the rabbis differentiated between prophecy during Biblical times and prophecy in their own days. An example given by Glatzer comes from a third-century figure, R. Reuven, who compared the prophetic (i.e., Biblical) period to the presence of a king in his city, subsequently, upon the absence of the king there remained his statue. ${ }^{93}$ In this metaphor the statue does not exercise authority to issue edicts and judgments. Nevertheless, the statue serves an interim role in lieu of the absence of the real person. The voice of heaven is likewise understood to be a less authoritative form of revelation since the more direct forms of communication have ceased.

Another noteworthy point by Glatzer is the "worthiness" required by individuals to receive either the Ruach ha-Kodesh or any comparable prophetic experience.

\footnotetext{
${ }^{91}$ Kittel et al., Theological, 288.

${ }^{92}$ Kittel et al., Theological, 289.

93 See Canticles Rabbah 8:11. Quoted by Nahum Glatzer, Essays in Jewish Thought (University: University Press, 1978), 123.
} 
According to some rabbinic texts, there were various ways individuals could prepare to receive manifestations of God: studying Torah, ${ }^{94}$ being humble, and saying words of Torah in public. ${ }^{95}$ We even read of the bat kol ringing forth on several occasions to single out Hillel the Elder and Samuel the Small as meriting the bestowal of the Holy Spirit if it were not for their generation. ${ }^{96}$ Consequently, by study and good deeds we do find evidence of the Holy Spirit approaching or dwelling upon certain people; however, in contradistinction to the Biblical mode of prophecy, no radically new revelations were promulgated so as to alter the established religious order of the day. ${ }^{97}$ The bat kol then would serve the function as a counselor as well as revealing individuals' merit before God. However, against Glatzer it might be argued that this definition applies only in certain cases. There are numerous examples when no mention of merit is made in relation to the apparition of the "voice from heaven." 98 However, Glatzer’s definition may be pertinent to discussions of related forms of revelation and spiritual union also attested to at this time. ${ }^{99}$

\footnotetext{
${ }^{94}$ Glatzer quotes from another third-century figure, R. Joshua ben Levi, who regarded the presence of God as implicit in the Torah; cf. Canticles Rabbah 8:13; Leviticus Rabbah 35:6; Glatzer, Essays, 123-124.

${ }^{95}$ See Canticles Rabbah 1:8.

${ }^{96}$ See B. Sotah 48b. It is not explicit what specifically impeded the reception of the Holy Spirit. I think it is safe to presume that it had to do with some moral failing.

${ }^{97}$ Glatzer, Essays, 124 . He further comments that among other reasons, one strong possibility may have been to safeguard the community from opening itself to believing prophetic revelations propagated by groups like the Christians.

${ }^{98}$ A classic example is when it bellowed after three years of disagreement between the schools of Hillel and Shammai, where the "voice" laid the issue to rest. See B. Sh. 14b.

${ }^{99}$ Frederick Greenspahn, “Why Prophecy Ceased”, (Journal of Biblical Literature 108, n.1: 1989), 37-49.
} 


\section{Revelation and Mystery in Ancient Judaism and Pauline Christianity by Markus Bockmuehl (1990)}

Markus Bockmuehl in, Revelation and Mystery in Ancient Judaism and Pauline Christianity, asserts that the "voice from heaven" served various functions like providing direction in matters of controversy, declaring God's will on a particular matter, and answering or informing individuals of God's will. ${ }^{100}$ He also echoes Lieberman's view that it resembled divination. ${ }^{101}$ Furthermore, he does not consider it to be a direct continuation in the line of Biblical prophecy. ${ }^{102}$ Though the rabbis interpreted it to have limited authority, and thus unable to influence in matters like legislating Halacha, Bockmuehl remarks there was the exception of permitting a widow to remarry on the basis of a bat kol. ${ }^{103}$

\section{Prophetic Figures in Late Second Temple Jewish Palestine by Rebecca Gray} (1993)

Rebecca Gray makes note of the bat kol in passing in her section on the prophetic figure of Jesus Son of Ananias. ${ }^{104}$ According to Josephus, this person started decrying

\footnotetext{
${ }^{100}$ Markus Bockmuehl, Revelation and Mystery in Ancient Judaism and Pauline Christianity (Tübingen: J.C.B. Mohr, 1990), 107.

${ }^{101}$ Bockmuehl, Revelation, 107. He too references the work of Saul Lieberman, Hellenism in Jewish Palestine and includes Lieberman's examples of St. Antony and St. Augustine, construing as divine, words uttered without the visibility of a speaker. St. Antony decided to become a monk upon hearing Matthew 19:21. Similarly, St. Augustine heard the chance utterances of children which prompted him to read the Bible. Cf. ORIGINS chapter under the sub-heading Biblical Examples, 59.

${ }^{102}$ Bockmuehl, Revelation, 107.

${ }^{103}$ Bockmuehl, Revelation, 108; e.g. M. Yev. 16:6.

${ }^{104}$ Rebecca Gray, Prophetic Figures in Late Second Temple Jewish Palestine: The Evidence from Josephus (New York: Oxford University Press, 1993), 158-163.
} 
the impending destruction of Jerusalem around the year $62 \mathrm{CE}$. His oracle contained six verses, each beginning with the phrase "a voice" and then proceeding to articulate the oracle. ${ }^{105}$ Consequently, and rightly so I would add, Rebecca Gray interprets this anonymous "voice" as synonymous with the bat kol, since it so well attested in the literature of that period. She recognizes that it is perceived to have operated as a kind of substitute of God's prophetic word, during a time where such prophecy was non-existent. However, based on David Aune's research in Second Temple texts, she deduces that “voice” can safely be interpreted as "the voice of God.”106 Hence, per Aune, Jesus' reference to "a voice” maybe understood to be none other than God's voice.

The point of including this detail is to suggest that despite the substitutionary role Gray and others have ascribed to the bat kol, one cannot completely remove it as being a form of divine communication. Perhaps, the modification bat was employed because of the uncertainty of the person relaying the message (in case it was not God), nevertheless it was understood to be expressing God's will or judgment. What is intriguing is that this form of communication can evoke complete awe and fear in the listener, in its random appearances, while on the other hand it may be dismissed, misconstrued, or ignored as being merely another voice from the crowd (though there are not many instances in rabbinic literature to support this reaction). Hence, it both presumes to confirm God's

\footnotetext{
${ }^{105}$ Gray, Prophetic Figures, 159.

${ }^{106}$ She refers to David Aune’s work Prophecy in Early Christianity, (Grand Rapids: Eerdmans, 1983), 160.
} 
absence of direct revelation (i.e. Holy Spirit) yet it also confirms God's ongoing

communication in an oblique manner. ${ }^{107}$

\section{The Sinner and the Amnesiac by Alon Goshen Gottstein (2000)}

Alon Gottstein discusses the bat kol throughout portions of his book, The Sinner and The Amnesiac: the Rabbinic Invention of Elisha Ben Abuya and Eleazar Ben Arach. In interpreting the story of the oven of “Aknai” where R. Eliezer ben Hyrcanus is excommunicated, he views the bat kol as heavenly and yet distinct from God. ${ }^{108}$ I will discuss this story in more detail in the "Categories" chapter. For now I wish to layout a basic outline of the story: the rabbis gathered to decide whether an oven cut into pieces was ritually clean or unclean. R. Eliezer was of the position that it remained clean while the rest of the sages ruled unclean. A heated debate ensued and R. Eliezer's arguments were rejected. This is followed by miraculous feats which backed R. Eliezer's authority on the matter. Each sign is adamantly rejected by the rabbis including, ultimately, the bat kol.

\footnotetext{
${ }^{107}$ A source I will list here is the article "Bath Kol” by Rabbi Louis Jacobs in The Jewish Religion: A Companion (Oxford: Oxford University Press, 1995), 47. Similarly to others, he defines the term as being, "the lowest form of direct divine inspiration." What is noteworthy is his mention of Jewish mystical thought preserving the idea that such an esoteric experience is still a possibility. He notes the late-twelfth century work of Judah Ha-Levi known as Kuzarri (essay 3,11), where the writer affirms that an authentically pious person who is continually aware of God's presence is capable of experiencing the bat $\mathrm{kol}$ like the sages of old. However the person should be in a holy place (i.e. the land of Israel), since practically all examples occurred in such a location. In such case, the bat kol becomes a privileged from of mystical experience rather than a lesser form of revelation as some scholars posit.

108 See Alon Goshen Gottstein, The Sinner and the Amnesiac: The Rabbinic Invention of Elisha Ben Abuya and Eleazar Ben Arach (Stanford: Stanford University Press, 2000), 353, n.129.
} 
Gottstein proposes two main functions that can be ascribed to the "voice from heaven.” The first is a calling to participate in holy activities like Torah study. ${ }^{109}$ R. Joshua ben Levi (middle third-century CE) is attributed to have stated, "Every day a divine voice [bat kol] goes forth from mount Horeb, proclaiming and saying, 'Woe to mankind for their contempt of the Law!'110 A second and more pervasive function, according to Gottstein, is revelation of the protagonist's status either in the present world or in the world-to-come. ${ }^{111}$ Glatzer and Marmorstein also mentioned the roles of the "heavenly voice" in affirming status and merit in the present world and in the world-tocome; this function constitutes one of the categories in this thesis.

Gottstein comments that Elisha Ben Abuya is known as "the only rabbinic figure who has come to be known as a sinner, an apostate, and a heretic.”112 Based on a careful comparison of the two variant readings of the Elisha ben Abuya story, found in the Jerusalem and Babylonian Talmudim, Gottstein notices differences in how the bat kol is employed in Talmudic writings. ${ }^{113}$ For instance, he espouses that in the Bavli version the bat $\mathrm{kol}$ is respected while in the Yerushalmi its absence is indicative that its significance is diminished, ${ }^{114}$ which according to Gottstein, is due to the different emphases of the

\footnotetext{
${ }^{109}$ Gottstein, The Sinner, 100.

${ }^{110}$ M. Avot 6:2. Translation by Herbert Danby, The Mishnah (Oxford: Oxford University Press, 1933), 459.

${ }^{111}$ Gottstein, The Sinner, 100. E.g. in the Bavli: Ber. 12b, 61b; Ta. 29a; M.K. 9a; Ket. 103b; A.Z. 10b, 17a, 18a.

112 Gottstein, The Sinner, 21.

113 The story is found in the B. Chagigah $14 \mathrm{~b}$ and in J. Chagigah 2:1.

${ }^{114}$ Gottstein, The Sinner, 202. Gottstein considers the Bavli version to be the earlier and original one.
} 
redactors. In addition, the Bavli has the "heavenly voice" exhorting Elisa to take up his sinful ways ${ }^{115}$ while the Yerushalmi reacts to him sinning via the "heavenly voice." In my view, Gottstein’s research guides the reader to understand the "heavenly voice" as a highly-versatile tool employed strategically by the sages.

\section{Encyclopedia Judaica "Bat Kol” (article by Aaron Rothkoff, 2007)}

Aaron Rothkoff discusses the bat $\mathrm{kol}$ in an article in the Encyclopedia Judaica. ${ }^{116}$ Based on rabbinic sources, Rothkoff also attests to it being a form of divine communication through which God expressed his will, choice, and or judgment, particularly in lieu of the recognized cessation of Biblical prophecy vis a vis the rabbis. ${ }^{117}$ He documents some of its varied functions such as appearing during Biblical times and during cases of martyrdom. Furthermore, though generally heard audibly, the "voice” is sometimes portrayed as appearing in dreams. ${ }^{118}$

\section{Elijah and the Rabbis by Kristen H. Lindbeck (2010)}

Kristen Lindbeck also offers some thoughtful remarks concerning the bat kol. She compares it with the manifestations of heavenly messengers such as Elijah and angels. First, in contrast to the manner Elijah normally appears to individuals, the bat kol swoops down with generic phrases implying that it could potentially be heard by

\footnotetext{
115 Gottstein, The Sinner, 204.

${ }^{116}$ Aaron Rothkoff, "Bat Kol" Encyclopaedia Judaica, edited by Michael Berenbaum and Fred Skolnik (Detroit: Macmillan Reference USA, 2007).

117 See. Tosefta Sotah 13.2; B. Sanhedrin 11a, Sotah 48b.

118 See B. Hagigah 14b; B. B.B. 58a, 73b-74a.
} 
everyone. Second, the bat kol, appears to be the designated spokesperson to declare the fate of individuals, particularly in moments of sudden death or martyrdom, whereas Elijah and angels do not assume such a task.

In addition, she also identifies two aspects of the bat kol. The first and less common type is the oracular function in which words and or phrases are uttered that in turn reveal God's will in various matters. ${ }^{119}$ The more prevalent manifestation proceeds directly from the supernatural and is understood to be God's voice. ${ }^{120}$ Moreover, she detects two primary functions. The first and more abiding role is that of herald of individuals' fate in the afterlife, so as to announce upon the deaths of individuals that they have merited entry in to the world to come. The second, and related, function is to provide commentary on the worthiness of individuals. ${ }^{121}$

In my estimation, her overall view of the bat kol, is well-informed. She defines it as, "God's word filtered through an angelic or cosmic loudspeaker."122 And in terms of comparison with Elijah, she notes that Elijah normally appears to empower individuals, such as teaching in rabbinic-fashion and giving wealth to the poor, whereas the bat kol normally curtails human potential. ${ }^{123}$ I think her commentary succinctly and successfully

\footnotetext{
${ }^{119}$ Kristen H. Lindbeck, Elijah in Rabbinic Culture and the Wider Culture of Late Antiquity (Columbia University Press, 2010), 55.

${ }^{120}$ Lindbeck, Elijah, 55.

${ }^{121}$ Lindbeck, Elijah, 56.

${ }^{122}$ Lindbeck, Elijah, 55.

${ }^{123}$ Lindbeck, Elijah, 44-45, 57.
} 
explains the general nature and function of the "voice.” Her research provides a solid framework and foundation through which to proceed with my own analysis.

\section{On the Question of the "Cessation of Prophecy" in Ancient Judaism by L. Stephen Cook (2011)}

Another source that concisely addresses the "voice from heaven" is Stephen L. Cook’s work, On the Question of the "Cessation of Prophecy" in Ancient Judaism. He writes of it as being conceived as a fallible substitute for the Holy Spirit and he views the rabbis displaying a generally ambivalent attitude towards its authority. ${ }^{124}$ Cook reads the literature of the Second Temple period to warrant lower forms of prophecy ${ }^{125}$ in light of a general consensus that the Biblical era of prophecy had ended. These supplementary forms of revelation include pseudepigraphic seers, Josephus’s prognostications, prophetic texts from the Teacher of Righteousness, and the rabbinic bat kol. ${ }^{126}$ Thus, he views it as the continuing voice of God in an era where it was believed that God's manifest presence was removed. ${ }^{127}$

\section{Conclusion}

\footnotetext{
${ }^{124}$ Stephen L. Cook, On the Question of the "Cessation of Prophecy" in Ancient Judaism (Tübingen: Mohr Siebeck, 2011), 159. The text Pesikta Rabbati 35 essentially states that if all of Israel would go up to the land, then the Presence would dwell in it, but if not, they would only have the echo of the bat kol; translation from, Stephen L. Cook, On the Question of the "Cessation of Prophecy" in Ancient Judaism (Tübingen: Mohr Siebeck, 2011), 160. Here we read how God's presence is substituted by the less preferred "voice from heaven."

125 Cook, On the Question, 175.

${ }^{126}$ Cook, On the Question, 175.

${ }^{127}$ Cook, On the Question, 172.
} 
Throughout this chapter I have presented major scholarly works on the enigmatic bat kol. This review is not intended to be exhaustive but comprehensive enough for the reader to acquire a substantial overview of important scholarly views on the bat kol. The sources have been compiled chronologically, that is in order of date of publication, beginning around the late eighteenth century, which exhibits several Christian scholars, and more Jewish scholars in the twentieth. The following table is a snapshot view of the scholarly views within this review concerning the rabbinic "voice from heaven."

Table 1: Major views of bat kol with author's name and dates of publication.

\begin{tabular}{|c|c|c|c|c|c|c|}
\hline & & & & & & \\
\hline Echo & $\begin{array}{l}\text { Blau \& } \\
\text { Kohler } \\
\text { (1906) }\end{array}$ & $\begin{array}{l}\text { G. F. } \\
\text { Moore } \\
\text { (1927) }\end{array}$ & & & & \\
\hline $\begin{array}{l}\text { Inner } \\
\text { Thoughts }\end{array}$ & $\begin{array}{l}\text { J. Nicholson } \\
\text { (1858) }\end{array}$ & $\begin{array}{l}\text { S. Louis } \\
\text { (1893) }\end{array}$ & & & & \\
\hline $\begin{array}{l}\text { Divine } \\
\text { Harbinger }\end{array}$ & $\begin{array}{l}\text { Blau \& } \\
\text { Kohler } \\
(1906)\end{array}$ & $\begin{array}{l}\text { A. } \\
\text { Guttmann } \\
\text { (1947) }\end{array}$ & $\begin{array}{l}\text { M. } \\
\text { Bockmuehl } \\
\text { (1990) }\end{array}$ & $\begin{array}{l}\text { A. G. } \\
\text { Gottstein } \\
\text { (2000) }\end{array}$ & $\begin{array}{l}\text { A. } \\
\text { Rothkoff } \\
\text { (2007) }\end{array}$ & $\begin{array}{l}\text { K. } \\
\text { Lindbeck } \\
\text { (2010) }\end{array}$ \\
\hline $\begin{array}{l}\text { Lesser } \\
\text { Form of } \\
\text { Prophecy }\end{array}$ & $\begin{array}{l}\text { J. Nicholson } \\
\text { (1858) }\end{array}$ & $\begin{array}{l}\text { M. } \\
\text { Kadushin } \\
(1952)\end{array}$ & $\begin{array}{l}\text { A.J. } \\
\text { Heschel } \\
\text { (1966) }\end{array}$ & $\begin{array}{l}\text { N. Glatzer } \\
\text { (1978) }\end{array}$ & $\begin{array}{l}\text { R. Gray } \\
\text { (1993) }\end{array}$ & $\begin{array}{l}\text { L.S. } \\
\text { Cook } \\
\text { (2011) }\end{array}$ \\
\hline $\begin{array}{l}\text { Oracle/a } \\
\text { voice } \\
\text { from a } \\
\text { Crowd }\end{array}$ & $\begin{array}{l}\text { E. Abbott } \\
\text { (1903) }\end{array}$ & $\begin{array}{l}\text { Blau \& } \\
\text { Kohler } \\
\text { (1906) }\end{array}$ & $\begin{array}{l}\text { A. } \\
\text { Guttmann } \\
\text { (1947) }\end{array}$ & $\begin{array}{l}\text { S. } \\
\text { Lieberman } \\
(1950)\end{array}$ & $\begin{array}{l}\text { M. } \\
\text { Bockmuehl } \\
\text { (1990) }\end{array}$ & $\begin{array}{l}\text { K. } \\
\text { Lindbeck } \\
\text { (2010) }\end{array}$ \\
\hline $\begin{array}{l}\text { Haggadic } \\
\text { Material }\end{array}$ & $\begin{array}{l}\text { A. } \\
\text { Marmorstein } \\
\text { (1950) }\end{array}$ & $\begin{array}{l}\text { O. Betz } \\
(1974)\end{array}$ & & & & \\
\hline
\end{tabular}

There are degrees of overlap among scholars in terms of definitions and functions. For example, Nicholson, Kadushin, and Heschel all identified the bat kol as a lower grade 
of prophecy popular during Second Temple times. John Nicholson and S. Louis mentioned the possibility of the bat kol representing the thoughts of the inner people or a random voice from among a crowd. Other scholars such as Lieberman and Bockmuehl referred to its occasional oracular function, though such cases are marginal compared to other cases in the entire rabbinic corpus. This thesis seeks to add more detail and perspective to this ongoing discussion. I will attempt to demonstrate that the bat kol operates, primarily, as a divine mouthpiece that reveals information concerning individuals' status in this world and in the "world to come.” By the same token, I suggest, we discern the voice of the sages instructing the people in typical Haggadic fashion through these stories which were delivered during the weekly homilies at the local synagogues.

Another area of overlap among scholars is that the basic meaning of bat is an “echo” or "resonance.” 128 The main proof text for this definition comes from the Midrash, Canticles Rabbah 1:3, which reads, “Just as this oil has no bat kol [when poured out] so also Israel will have no bat kol in this world, but in the world to come.” Conversely, Blau and Kohler interpret bat as referring to a disembodied voice and the kind of quality of the voice heard.

Kristen Lindbeck suggests that it invokes the imagery of a "cosmic loudspeaker” which proclaims that which the heavenly King decreed. In this regard, the bat kol is comparable with angelic beings and their conventional task as divine messengers. It is

\footnotetext{
${ }^{128}$ Another possibility is that bat was meant to denote its status as an offspring of Biblical prophecy.
} 
not surprising, therefore, that in at least one reference the angel Gabriel is identified with the bat kol. Still, the "daughter of a voice" remains anonymous in rabbinic literature, except in this one occasion where it is identified with the angel Gabriel. ${ }^{129}$

We notice that various functions have been identified. Alexander Guttmann proposed its participation in Halachic matters, while also reading polemical motives on the rabbis' behalf. Gottstein suggested two functions: revelation of statuses in the world to come and calling to holy activities, such as Torah study. And Lindbeck proposed that it served the twofold function of a transmitter of God's voice and a type of oracle. Even though the bat kol is easily identified in rabbinic literature, its exact purpose is not explicit and perhaps was not so to begin with. It is reasonable to deduce that it had various functions as demonstrated by these scholars. In fact, my own categories will also suggest that it was multifaceted. Moreover, I will seek to synthesize my own categories in an effort to discern how they relate and what they reveal about the bat kol's function.

Important functions have already been noted by scholars and this thesis is a continuation of such efforts. Perhaps my findings will not be radically different from previous research though I am employing a more comprehensive overview than has been realized thus far by reviewing each instance in the Babylonian Talmud where the bat kol appears, and by expositing ten stories I consider representative of larger and important categories. In terms of approach, I employ the same method put forth primarily by S. Louis. Louis carried out a brief overview of numerous stories in order to elucidate his proposed categories; it has been about one-hundred and twenty years since he published

${ }^{129}$ B. So. 33a. 
his work. I seek to imitate his work, by also exegeting about ten different stories each representing a distinct category. While some categories already identified will be appropriated in this thesis (e.g. statuses in the world to come, and Halacha), I have omitted others (e.g., maxims and interactions with Biblical characters) since I do not discern a strong enough emphasis of such themes so as to label it as its own category. My selection of four categories along with a miscellaneous one, should demonstrate that these labels are not final, but are the ones I considered most useful for grouping different stories. There remains the possibility of creating new labels or reapplying old ones not addressed here. By seeking to elucidate the function of the bat kol I will present details concerning its literary use, in addition to social and historical aspects of such literature, so at to better unravel its function.

Lastly, I echo Marmorstein's understanding which construed the bat kol as an important part of Haggadah (lore) employed for didactic purposes. Essentially, the bat kol conveyed God's immanence to the people. Moreover, I will note how the bat kol reflects rabbinic approaches to various contemporary issues, such as alleviating suffering and evil and assuring God's judgment over the people responsible for destroying the Temple. My approach will be comparative in nature, and in this way draws from Otto Betz' comparisons with other literatures. The following chapter is dedicated to exploring parallels of the bat kol with Biblical and Apocalyptic literature, primarily. This is carried out by depicting parallels such as in language and themes. These parallels, I believe, are indicative of how texts were translated and appropriated by the rabbis so as to reflect similarities between anonymous heavenly voices (primarily from the Hebrew Bible) and the bat kol of rabbinic literature. 


\section{ORIGINS}

\section{Introduction}

Before proceeding to present specific cases of the bat kol and their relevance for elucidating its overall function in the Babylonian Talmud, I will explore the probable origins of this term. Indeed, the fact that it was employed by the rabbis at all suggests that it contained value, both for themselves as well as their intended audiences. Furthermore this seems to be the case for several peoples in the ancient world. ${ }^{130}$

The sages believed that the voice that spoke to Abraham, Moses, David and others in Biblical times was none other than the bat kol. ${ }^{131}$ Nevertheless the phrase, bat kol, does not exist in the Biblical text or any other ancient document prior to the writings of the rabbis. However, we do note many anonymous voices from heaven interrupting in various Biblical stories; this chapter will survey a handful of these key events. Therefore, I view the bat kol as closely derived from the Biblical corpus. This conclusion is not definitive; rather, I suggest that the voices (kolot, pl.) of the Biblical narrative best resemble the bat kol in terms of language and roles. In fact, it is probable that multiple streams of thought exercised influence.

Otto Betz, for example, understood the rabbinic heavenly voice as being comprised of several sources: “Ancient Oriental, OT and especially apocalyptic-visionary

\footnotetext{
${ }^{130}$ Arabic poetry contains a later cognate, hatif, which according to William Kirkpatrick means, "crying, exclaiming, but commonly signifying an angel or aerial spirit, who declares to mortals the will of Heaven, or suggests to them how they should act in order to obtain their desires; cf. William Kirkpatrick, $A$ Vocabulary Persian, Arabic, and English... (London: Cooper, 1785), 191.

${ }^{131}$ Kitto, Cyclopedia, 304.
} 
traditions are adopted here [referring to the bat $\mathrm{kol}$ ] and developed and formalized under the impress of the divine transcendence. The belief in oracles, popular in the Hellenistic world, ${ }^{132}$ also had some influence." ${ }^{133}$ In Betz’s view, a multiplicity of sources fed into the emergence of the rabbinic "heavenly voice.” I think Betz's observation is well taken given the resemblances between the several bodies of literature. The purpose of this chapter is to present some of these similarities.

Concepts are best understood when placed within literary-historical contexts. This in turn helps elucidate their nature, development, and purpose. Though tracing the manner in which different cultures and or texts may have had bearing is not simple, however. The Babylonian Talmud depicts different purposes for the bat kol; that is, it is not uniform and in this regard resembles other rabbinic writings. Despite its variety in function, the contours of categories become visible. These are overarching themes that once synthesized produce a more cohesive view of the purpose(s) of the bat kol. That is to say, in discovering functionality we are in a better position to understand origins, notwithstanding other factors which could have shaped the development and usage of the bat kol. Indeed, identifying a precise origin for the bat kol is difficult, yet my aim in this chapter is to present suggestive evidence that depicts similar uses in other literatures so as to demonstrate bodies of ancient literatures the rabbis were potentially influenced by.

\footnotetext{
132 John Collins in his commentary on Daniel wrote that "divine or heavenly voices" are more widely attested in the Hellenistic world. He cites an example from Theopompus (fourth century BCE) who narrates that when Epimenides wanted to build a shrine for the Nymphs, "a voice burst from heaven" telling him to build it for Zeus instead. Cf. Daniel: A Commentary on the Book of Daniel (Minneapolis: Fortress Press, 1993), 231, n.134.

${ }^{133}$ See Kittel et al., Theological, 288.
} 
The rabbis did not explain the origin of the bat kol per se. Yet, key statements are found in the Tosefta: ${ }^{134}$ "After the death of Haggai, Zechariah and Malachi, the last Prophets, the Holy Spirit ceased from Israel; nevertheless they were spoken to through the Bat Kol.” ${ }^{135}$ A clear demarcation is made after the last Biblical prophets; it is presumed the Holy Spirit ${ }^{136}$ desisted from its revelatory activities. Frederick Greenspahn in his article, "Why Prophecy Ceased," connected the loss of the Holy Spirit with the Babylonian Exile; its presence (and subsequent lack thereof) was an important distinction between the First and Second Temples. ${ }^{137}$ Moreover, Arthur Marmorstein suggested the rabbis viewed the destruction of the Second Temple as the termination of prophecy. ${ }^{138}$ Others like Ephraim Urbach and Nahum Glatzer interpreted this statement as polemic rhetoric against groups such as Christians who strongly appealed to the prophetic for their message and viability and who may have claimed exclusive possession of the Holy Spirit, at the exclusion of other groups. Either way, the basic underlying idea is that a shift

\footnotetext{
${ }^{134}$ Tosefta is Aramaic for "supplement." It is dated to the time of the Mishnah; ca. 200CE often providing complementary and supplementary material to the Mishna, such as Biblical justifications for legal rulings. According to Moore, it is quoted in the Talmud as a Baraita, which is an "extraneous" tradition of the sages of Israel from the first two centuries CE. See Moore, Judaism, vol. I, 97.

${ }^{135}$ See Tosefta Sotah 13:2. Similar statements are found in B. Yoma 9b; Sotah 48b; San.11a.

${ }^{136}$ Frederick Greenspahn noted the interchange between "Spirit of prophecy" and "Holy Spirit" in the Aramaic translations of the Hebrew Bible known as Targumim; cf. Frederick Greenspahn, "Why Prophecy”, 37.
}

${ }^{137}$ See J. Ta. 65a; B. Yo. 21b; Numbers Rabbah. 15:10; Canticles Rabbah. 8:9. Hence for Greenspahn he sees the rabbinic position as generally deeming the withdrawal of the Holy Spirit sometime between the sixth-fourth centuries BCE; Greenspahn, "Why Prophecy", 38. The First Temple was erected by Solomon ca. tenth century BCE and stood until the destruction by the Babylonians in 586 BCE. The Second Temple was built in latter part of the sixth century BCE by Ezra and Nehemiah (with major renovations by Herod) until its destruction by the Romans in $70 \mathrm{CE}$.

${ }^{138}$ See Arthur Marmorstein, Studies in Jewish Theology (London: Oxford University Press, 1950), 38, n.9. Y. Kauffman considered sin to be the main reason for the rabbis' position that the Holy Spirit had departed; cf. Greenspahn, "Why Prophecy”, 39. 
occurred in terms of revelation; namely that the Holy Spirit is somehow replaced by the bat kol.

\section{A. "End" of Prophecy}

The view that Biblical prophecy ceased finds further backing in other Second Temple works: $1^{\text {st }}$ Maccabees, $2^{\text {nd }}$ Apocalypse, and Baruch. ${ }^{139}$ Conversely, writings from this same period also affirm the ongoing work and activity of the Holy Spirit and or prophecy: Philo, Wisdom of Solomon, Josephus, and Paul just to name a few. ${ }^{140}$ Furthermore, rabbinic texts also speak of "small prophecy” and or related activity. ${ }^{141}$ Moreover, the bat kol is sometimes retrojected into the Biblical narrative, during which time the Holy Spirit was presumably active among God's people. Why then would they depict the bat $\mathrm{kol}$ as active prior to the death of these last mentioned prophets if it allegedly arose afterwards? ${ }^{142}$ There does not appear to be a straightforward answer. Furthermore, it is clear that this view was not unanimous among the sages. A possible harmonization is to read this statement not as prescriptive but descriptive. In other words the rabbis were perhaps emphasizing what they reckoned to be the more pervasive form of revelation. This popular method of divine manifestation was the less authoritative “daughter of a voice” and not the Holy Spirit or Spirit of prophecy. ${ }^{143}$

\footnotetext{
139 Greenspahn, “Why Prophecy”, 37.

${ }^{140}$ Greenspahn, “Why Prophecy”, 42.

${ }^{141}$ See M. Sa. 1:5; 11:1, 5, 6; B. Sa. 90a; Pe. 66b; cf. Greenspahn, “Why Prophecy”, 44.

${ }^{142}$ Notably Midrash Haggadah, in which the bat kol appears some nearly 180 instances.

143 I.e., the Holy Spirit.
} 
Nevertheless, scholars have suggested that prophecy did not actually "cease” as the statement implies, rather it is better conceived as having experienced a significant shift in terms of the character and mode of revelation. ${ }^{144}$ Stephen L. Cook thus made the following observation: "Jewish literature of the Second Temple period picks up on the concept of the "degree" of prophecy with its affirmation that other, lower forms of revelation also exist in addition to prophecy." 145 Prophets were active and the Holy Spirit was integral to the vibrancy of various religious groups such as the Christians and Qumran community, not to mention the rabbis themselves.

Another possible explanation is that the rabbis sought exclusive authority to exert their influence and teachings without having to deal with the claims of rival charismatic groups. Thus, they neatly contrived the Holy Spirit as having departed by the latter part of the Second Temple period. The fact that in several passages prophets are denied the right to make legal decisions ${ }^{146}$ seems to fit this paradigm. Furthermore, if prophets were no longer around, why would there be a perceived need to limit their legal decisionmaking powers? We find the following peculiar statement in the Babylonian Talmud: "In the words of R. Abdimi: Since the destruction of the Temple, prophecy has been

\footnotetext{
${ }^{144}$ Alex Jassen suggests in Prophets and Prophecy in Qumran that, "Prophecy and prophetic phenomena persist in some segments of Second Temple Judaism, though in a modified manner. Accordingly, terms such as ‘cessation’ or ‘disappearance' are inappropriate.” (AJS Review 32 (2): Cambridge University Press, 2008), 303.

${ }^{145}$ See Stephen L. Cook, On the Question of the "Cessation of Prophecy" in Ancient Judaism, (Tübingen: Mohr Siebeck, 2011), 175.

${ }^{146}$ See Tosefta Sanhedrin 14:13; J. Megillah 70d; B. Yoma 80a; B. Terumah 16a, B. Sh. 104a; B. Megillah 14a.
} 
taken from the prophets and given to the sages."147 According to this statement, the sages were the bonafide leaders and judges in matters of prophecy/revelation. Frederick Greenspahn elaborates:

Judaism probably could not have survived in any other way. Temporal authorities were unlikely to tolerate those claiming divine sanction for what were perceived as revolutionary activities, just as the rabbis could hardly tolerate a rival vision of God's message. The claim that the Holy Spirit was no longer operative removed a very real threat to rabbinic authority, both in principle, since the rabbis did not claim direct contact with God, and in practice, given the reality of others who did. ${ }^{148}$

It could very well be, that the bat kol was “selected” as God's supernatural agent in lieu of the Holy Spirit's perceived absence. This position was put forth by Ephraim Urbach who suggested this assertion by the rabbis may be a rebuttal to the claim of several church fathers of the removal of the Holy Spirit. ${ }^{149}$ However, even prior to the advent of schismatic groups like Christianity, the rabbis, according to Greenspahn, “sensed something about the Hellenistic period... which led them to conclude that the Holy Spirit had departed from Israel.”150 It is unclear what precisely Greenspahn is referring to in his commentary on the rabbis discerning the withdrawal of the Holy Spirit during the

\footnotetext{
147 See B. B.B. 12a. Similarly in the Midrashic work, Seder Olam Rabbah § 30, comments that prior to Alexander the Great, "the prophets prophesied with the Holy Spirit; hereafter, incline your ears and obey the sage’ words.” Quoted in Frederick Greenspahn, "Why Prophecy”, 47.

${ }^{148}$ Greenspahn, "Why Prophecy”, 49.

${ }^{149}$ Which according to some of the Church Fathers was a consequence for the rejection of Jesus of Nazareth as Messiah, hence Urbach suspected this led the rabbis to place the departure of the Spirit before the events of the first century CE so as to rebut those claims. In such a case, it is not clear why the rabbis would have entertained such a claim to begin with.

${ }^{150}$ Greenspahn, “Why Prophecy”, 47.
} 
Hellenistic period, especially since the Jews were dealt with favorably by the Macedonian ruler. ${ }^{151}$

The rabbis' advocacy for the cessation of normative prophecy and for the rise of the bat kol may have been an effort to preserve their way of life and teachings in light of competing sects. Moreover, this understanding may explain why the bat kol is conferred a secondary-status so to speak in terms of revelation, and is primarily a non-factor in terms of influencing legal-rulings (Halacha). ${ }^{152}$ Thus if a majority rabbinic view subscribed to the position that prophecy had ceased, this train of thought may be a major reason for the popularity of the bat kol.

In summary, we discover that both the rabbinical corpus and other Second Temple texts attribute an "end" of prophecy with the last of the Biblical prophets. However, this did not imply that revelatory experiences were non-existent nor that the Holy Spirit’s prophetic activity had completely withdrawn. The so-called "end" of prophecy raises questions that are connected to the bat kol. It appears there were practical reasons for espousing that prophecy no longer existed such as to safeguard rabbinic authority.

\footnotetext{
${ }^{151}$ Seder Olam Rabbah 30 states that prior to the advent of Alexander, the prophets prophesied with the Holy Spirit, afterward, the people should incline their ears to obey the words of the sages.

152 One, if not the most, famous example is the incident of the "oven of Aknai," where the sages reject the bat kol's intervention on R. Eliezer's behalf in a Halachic debate. cf. B. Bava Metzia 59b; J. M.K. 3:1, 81c$\mathrm{d}$. The notable exception to this rule is when the bat kol chimed in to show approval of the house (school) of Hillel over the house (school) of Shammai in what was supposedly a prolonged legal debate; cf. B. Eruvin 13b. Several passages reference the school of Hillel allowing the testimony of the bat kol while the school of Shammai prohibited such, cf. T. Naziruth 1; B. Yev. 122a; J. Nazir 51b.
} 


\section{B. Approach}

I seek to couch the theme of the bat kol in a literary-historical framework. Writings from the ancient world exhibit the convergence of the supernatural with the natural and commonly utilized narrative discourse for such purposes. Granted groups like the Sadducees, ${ }^{153}$ did not assent to belief in the paranormal ${ }^{154}$ in contrast to the other contemporary groups (i.e., Pharisees, Christians, Qumranites) who did subscribe to such notions. Moreover, Qumran’s Pesher commentaries, the Christian’s interpretation of Biblical prophecies referring to Jesus of Nazareth, and the variegated, rabbinic method of Scripture interpretation, all demonstrate the outworking of revelation through exegesis. This spiritual sensitivity exhibited in these works also draws parallel with apocalyptic writings of the late-Second-Temple period.

My approach seeks to account for the bat kol within Judaism’s gargantuan and seminal work, the Babylonian Talmud. ${ }^{155}$ Moreover, this chapter seeks to present cognates within other ancient literature in order to identify possible sources of influence upon rabbinic thought, by presenting clear parallels in function and theme. I will employ a philological and literary approach. I will present specific passages that are relevant for the purposes of comparing with stories depicting the bat kol, analyzing concepts and themes in the process.

\footnotetext{
153 Primarily a priestly and aristocratic group.

154 E.g. angels, resurrection.

155 It contains nearly 2,500,000 words. The Yerushalmi (Jerusalem), 800,000. Cf. Raphael Patai, Gates to the Old City, (Detroit: Wayne State University Press, 1981), 159.
} 
However, I will briefly comment on a few basic and possible scenarios from the standpoint of the writers. ${ }^{156}$ The writer could have transcribed a given tradition and or event believing it to have been historically true (eye-witness or not) and therefore important to promulgate. Or the writer (and perhaps the intended audience) may have been cognizant of its fictional composition yet acknowledged its value, such as for didactic purposes. In such a case, why would it be appealed to in order to convey moral teachings? In other words, what authority did the bat kol enjoy? Theoretically a single event could have been sufficient to foster additional legends, to say the least. Nevertheless the point to be made is that it contained intrinsic value for the rabbis as reflected in their stories. Consequently, it also carried worth for the common people, whether or not its historicity can be ascertained by modern scholars.

\section{Rabbinic Literary Categories, Biblical and Apocalyptic Literatures}

Ancient rabbinic literature was multilayered. Scholars tend to distinguish two broad categories in this voluminous body of writings: Halacha (legal instruction) and Haggadah (lore/storytelling). The law or Halachic component, is meant to transmit the proper observance expected of Jews per the ancient sages/rabbis. Haggadah is understood as a literary category of ethical teachings and or interpretations typically 
transmitted through stories. ${ }^{157}$ In fact, scholars have suggested there is no single translation which fully encapsulates its vast range of meanings. ${ }^{158}$

Jeffrey Rubenstein remarks that rabbinic stories, “...should not be seen as historical testimonies but as rhetoric that serves the purposes of the storyteller(s). They relate deeds of the sages that 'could have happened' and speech that 'should have been spoken’ according to the storyteller's sensibilities." ${ }^{159}$ I seek to elucidate why it was employed by the rabbis. Surely, the pervasive number of occurrences found throughout the Talmudic writings and other related literature is not happenchance. ${ }^{160}$ Therefore in order to construe some plausible explanation for the presence and pervasiveness of this term, it is helpful to consider the beliefs of the sages which informed their writings. Lawrence Schiffman, for instance, has noted that later Haggadot ${ }^{161}$ were more influenced by apocrypha, pseudepigraphic, and apocalyptic elements than those produced by the

\footnotetext{
${ }^{157}$ Haggadah is used for the disclosing the purposes for the Biblical commandments but not for Halachic rulings; cf. Lawrence Schiffman, From Text to Tradition: A History of Second Temple \& Rabbinic Judaism, (Hoboken: Ktav Publishing House, 1991), 271.

${ }^{158}$ According to Raphael Patai, these meanings include: myth, legend, parables, folktales, allegories, idyllic tales, animal fables, all in narrative style. Yet in can also take the form of dialogue, mystical allusion, and moralistic advice. Brief examples may include: terse maxims, play on words, permutations, and ingenious play on Hebrew letters and their numerical values, cf. Raphael Patai, Gates to the Old City, (Detroit: Wayne State University Press, 1981), xxii-xxiii.

${ }^{159}$ See Jeffrey Rubenstein, Talmudic Stories: Narrative Art, Composition, and Culture (Baltimore: Johns Hopkins University Press, 1999), 8.

${ }^{160}$ I have found nearly 400 cases of the bat kol in Mishnah, Tosefta, Talmud, Targum, and Midrash. The purview of this study will be focused on the cases from the Babylonian Talmud, which contains approximately 70 episodes.

${ }^{161}$ Plural of Haggadah. These later stories include: Exodus Rabbah, Leviticus Rabbah, etc...cf. Schiffman, From Text, 236.
} 
Amoraim ${ }^{162}$ in the land of Israel. ${ }^{163}$ That is to say, according to Schiffman, Haggadot found in the Babylonian Talmud as well as in later documents, exhibit more apocalyptic elements features than its Palestinian counterpart.

A choice prophetic/apocalyptic text for various Jewish sects at the time was the book of Daniel. ${ }^{164}$ Daniel was typically esteemed as a prophet by the writers of antiquity. ${ }^{165}$ Scholars like Alex Jassen have interpreted chapter nine to be the locus for the nature of prophecy in the Second Temple period, namely, revelation through exegesis of Scripture ${ }^{166}$ and mantic wisdom or interpreting the future through signs. ${ }^{167}$ In chapter nine, God answers Daniel's prayers by sending Gabriel and disclosing the interpretation of the passage from Jeremiah 25: 9-12 which states that the nations (Judah included) would serve the king of Babylon for seventy years until they would in turn receive judgement from on high. Jassen thus explains this new form of prophetic revelation as,

\footnotetext{
162 The Amoraim are known as the teachers of the Talmud or Gemara (ca.220-525 CE).

163 James Kugel wrote about the connection between Midrash and apocalyptic sources in Two Introductions to Midrash, quoted by Daniel Boyarin in Intertextuality and the Reading of Midrash, (Bloomington: IN, 1990), 13.

${ }^{164}$ John Collins notes that in the B. Sanhedrin 94a, the companions of Daniel (10:7), are identified as Haggai, Zechariah, and Malachi. These are purported to be greater than Daniel in that they were deemed prophets. Yet Daniel is elevated because he alone saw the vision. John Collins, Daniel: A Commentary on the Book of Daniel (Minneapolis: Fortress Press, 1993), 52.

165 See Josephus' comments in Ant 10.11.7, 266-268, where he upholds him as one of the "greatest prophets."

${ }^{166}$ See Alex Jassen, Prophets and Prophecy in Qumran Community, (AJS Review 32 (2): Cambridge University Press, 2008), 299-334.

167 John Collins notes that the most prominent precedent for this practice is the Biblical figure of Joseph. He also notes that mantic wisdom was considered primarily gentile, and is polemicized by passages in Isaiah (44:25-26, 47:13). However, Collins affirms that Daniel espouses in the book that there is a superior wisdom and power in the God of the Jews. See John Collins, Daniel: A Commentary on the Book of Daniel (Minneapolis: Fortress Press, 1993), 49-50.
} 
"the careful interpretation and reapplication of the Scriptural record actualizes the divine communication.”168 Despite the rabbis’ statement that prophecy ceased with the death of Malachi, Haggai, and Zechariah, ${ }^{169}$ scholars have discerned a more nuanced reality, suggesting that there were actually degrees of prophecy instead. ${ }^{170}$ Furthermore, the book of Daniel is considered one of the earliest samples of an apocalyptic work and its similarities with apocalyptic literature through possible direct influence has been noted by scholars like John Collins. ${ }^{171}$

\section{A. Biblical Examples:}

The first passage to which I wish to draw the reader's attention is the fourth chapter of Daniel where a disembodied voice announces God's judgment on King Nebuchadnezzar. This story seems to best resemble rabbinic stories that describe a bat kol in characters and method of revelation. The Biblical account states that a voice literally "fell from the heavens." ${ }^{172}$ Verse 30 states that at the time Nebuchadnezzar was admiring his kingdom in his grandiose royal residence. It was as if Nebuchadnezzar, in

\footnotetext{
168 Jassen, Prophets, 323.

${ }^{169}$ See Tosefta Sotah 13:2 and parallel versions like J. Sotah 45b; B. Yoma 9b; Sotah 48b; Sanhedrin 11a, which state that they "made use of" משתמשין rather than they were "spoken to" משמיעין by the bat kol. Alexander Guttmann, The Significance of Miracles in Talmudic Judaism, (Cincinnati: Hebrew Union College Annual, 1947), 367, n.7.

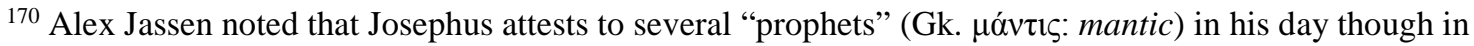

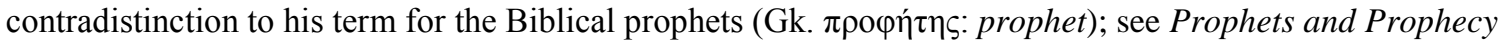
in Qumran Community, (AJS Review 32 (2): Cambridge University Press, 2008), 304. Collins noted references in Josephus to prophets; see JW 6.5.2 §§285-86; Ant 13.11.2 §§311-13; 20.5.1 §97; 20.8.6 § 169. John Collins, Daniel: A Commentary on the Book of Daniel (Minneapolis: Fortress Press, 1993), 57, n.467.

${ }^{171}$ See Collins, Daniel, 58.

172 Aramaic nephal; "to fall” cf. William Holliday, A Concise Hebrew and Aramaic Lexicon of the Old Testament, (Grand Rapids: Eerdmans, 1988), 414.
} 
boasting about his accomplishments, was foolishly directing himself to heaven. Then in verse thirty-one, the narrative is interrupted with the phrase, ${ }^{173}$ עוד מלתא בפם מלכא or "while he was still speaking” and continues, קל מן שמיא נפל לך אמרין נבוכדנצר מלכא מלכותה עדת מנך a "voice from heaven fell [saying] to you it is said king Nebuchadnezzar the kingdom is taken away from you!”

Perhaps the most striking resemblance between this Biblical story and the rabbinic bat kol is the phrase introducing it. In rabbinic writings the bat kol is introduced in Hebrew as: יצאה בת קול (מן השמים) ואמרה ("a daughter of a voice went forth [from heaven] and said...”) and less commonly in Aramaic: נפקת ברת קלא (“a daughter of a voice went forth...”). This typical Hebrew phrase relates the same meaning as the Aramaic in Daniel chapter four. ${ }^{174}$ The heavenly judgment was impromptu, though King Nebuchadnezzar was forewarned through Daniel's earlier interpretation of the king's second dream. The interpretation was that his kingship would be temporarily suspended until he realized that all sovereignty and dominion belongs to God and He delegates such to whomever He pleases. ${ }^{175}$ Turning to the bat kol we find that it appears most of the time unannounced, withholds the identity of the speaker, ${ }^{176}$ and regularly announces decrees of judgment over certain individuals for better or for worse. The Biblical account

\footnotetext{
${ }^{173}$ Which may be literally rendered, "while the matter [was] in the mouth of the king."

${ }^{174}$ There are other noteworthy examples like Numbers 7:89, where Moses hears God's voice speaking to him from above the ark of the testimony in the tent of meeting. Isaiah 40:3; a "voice cries in the wilderness," 1 Kings 19:12 where God revealed himself in a still small voice to Elijah.

${ }^{175}$ See Daniel 4:1-27.

${ }^{176} \mathrm{D}$. Sperling opined that the rabbis chose to keep it anonymous due to the monotheistic character of rabbinic Judaism. See Akaddian Egerru and Hebrew Bat Kol, (New York?: JANES, 1972), 73.
} 
states that it literally "fell from the heavens." More than location from where the message emanates, the description of falling "from the heavens", denotes the overlap of the spiritual with the physical.

It is not surprising then to find in the Talmud creative embellishments of Nebuchadnezzar while introducing the bat kol. Such an example is found in the Babylonian Talmud, tractate Pesachim 94a where we read that Rabbi Yohanan ben Zakkai asks, "What rejoinder did the bat kol give to that wicked man [i.e. Nebuchadnezzar], when he said, "I will ascend over the tops of the clouds; I will liken myself to the Most-high'”' [quoting from Isaiah 14:14]. The text in Daniel does not include the verse quoted from Isaiah; this appears to be a rabbinic insertion to further accentuate the haughtiness of Nebuchadnezzar. In fact, the passage from Isaiah is actually couched in an oracle that is a direct taunt to the king of Babylon (i.e. Nebuchadnezzar) by a remnant of Israel. ${ }^{177}$ The rabbis were aware of the various Biblical contexts in juxtaposing this verse from Isaiah with Daniel chapter four. Hence, in classic Midrashic style, the rabbis astutely relate these two passages that both deal with the King of Babylon.

The answer to Rabbi Yohanan’s question is, “A heavenly voice called out and said to him: 'wicked man, son of a wicked man... who led the whole world in rebellion against Me during his reign... but to the nether world will you be brought down, to the depths of the pit!'” This homiletic commentary uses the notions of height and depth to

\footnotetext{
${ }^{177}$ From the Babylonian captivity or exile which is marked with destruction of Jerusalem in 586 BCE.
} 
accentuate God's judgment on Nebuchadnezzar. The book of Daniel later narrates Nebuchadnezzar's temporary stint of deranged activity (i.e. behaving like a wild-animal of the field) while the Talmudic version glosses over such details and preserves an even harsher and unremitting verdict: punishment in the afterlife.

Moreover, B. Shabbat 149b depicts the bat kol reproaching Nebuchadnezzar upon arriving in the realm of the dead, where those present are frightened to see him. ${ }^{178}$ This rabbinic story provides additional details to the prophetic words of Isaiah chapter fourteen, in which the King of Babylon is judged by God and is sent down to Sheol or the abode of the dead. The text reads that Rav Yehuda said in the name of Rav, "When that wicked man (Nebuchadnezzar) went down to hell, all the descenders of hell trembled. They said, 'Perhaps he has come to rule over them, or to be weak like them,' as it says, "Have you too become weak like us? Have you come to rule over us?”179 The Talmud then narrates that a bat kol went forth and said, "Whom do you surpass with beauty? Go down with, and you shall be laid with the uncircumcised.” ${ }^{180}$ The bat kol confirms God's judgment over King Nebuchadnezzar, as stated in the Biblical text, and therefore the people in Sheol need not worry of further harm perpetrated by this infamous king.

All three passages employ the dramatic intervention of a heavenly voice! The aforementioned rabbinic stories preserve and elaborate details from the Biblical text

\footnotetext{
178 The people were afraid because they knew of Nebuchadnezzar's alleged practice of sodomy. It is also found in B. Chg. 13a.

${ }^{179}$ Isaiah 14:10.

180 This is a quote from Ezekiel 32:19, which is a decree of judgement and lamentation over Pharaoh and other nations who are also proscribed to descend down into Sheol.
} 
through the creative style of Haggadah. I suggest the imprint of the Biblical narrative is clearly visible behind the rabbis' use of the bat kol in the above-mentioned stories. ${ }^{181}$ Nevertheless, this does not prove that the rabbis developed the notion of the bat kol from the book of Daniel specifically, though clearest parallels are, in my estimation, those between Daniel and rabbinic stories.

Another passage that is of interest occurs in Dan. 9:23. Daniel recounts that while he was presenting his supplications before the LORD the angel Gabriel appeared and said to Daniel, “At the beginning of your supplications a word [davar] went out, and I have come to declare it, for you are beloved. So understand the word and comprehend the vision.” The word for "went out” (yatzah) interestingly enough, comprises part of the markedly common phrase in the Talmud which is employed to introduce the bat ol $^{182}$ in addition to other rabbinic writings. The verb yatzah is overwhelmingly used to describe the appearance of the bat kol, it warrants comparison with places in Scripture where the term is also applied in addressing heavenly revelations. The text states that an answer proceeded (presumably from God) and was delivered via Gabriel.

The very name bat kol, literally “daughter of a voice,” may be indicative of its ancillary status in revelation. In other words, this label maybe interpreted as denoting a

\footnotetext{
${ }^{181}$ Scholars acknowledge the Bible as a major source for informing Haggadot. However as Raphael Patai noted, in Talmudic and Midrashic literature, some Haggadot do not derive from the Bible but from popular or individual fantasy; cf. Raphael Patai, Gates to the Old City, (Detroit: Wayne State University Press, 1981), xxix.

${ }^{182}$ Hebrew צית The passage of Isaiah 2:3 reads, "For from Zion will go forth (tetzei) torah and the word of the LORD from Jerusalem.” Interestingly enough, prophetic words from God, in the Bible, are described as moving through space and time. Examples of the bat kol reflect this notion of God's word taking on a life of its own, as it were, through language describing its origin, movement, and purposes.
} 
less authoritative form of divine communication, so as not to be confused with God's voice, albeit such a view remains speculative. As noted in the second chapter by various scholars, Marcus Jastrow also defines the term bat kol as an echo or reverberating sound. ${ }^{183}$ Moreover, when attached with the preposition beh, it signifies the daughter or product of something. And Jastrow notes the rabbis use bat in various compound phrases: bat or ("fit for fuel"), bat arah ("a sore on the foot"), bat eenah ("hole in a millstone through which the grain feeds through”). ${ }^{184}$

In the prophetic writings, such as in Jeremiah and Ezekiel, the word daughter is commonly applied for Israel collectively, it appears to personify Israel, through phrase such as “daughter of Zion” and “daughter of Jerusalem.” In summary, the rabbi’s phrase, bat kol, remains elusive. In my view the best explanation, as put forth by Jastrow, is the one explaining bat as a type of echo or reverberation. In this view, the bat kol does not stand for God's immediate communication but a response or communication relayed typically via an anonymous messenger. The idea underscores the invisibility of the messenger. Thus far, the parallels in language and concepts between the Biblical and rabbinical corpuses seem too close to be overlooked, making it plausible for the origins of the bat kol to be rooted in the anonymous voices of the Bible.

Another well-known passage that is relevant to this discussion is the story of Abraham's binding and (attempted) sacrifice of his son Isaac. This story is found in the

\footnotetext{
183 Jastrow, Dictionary, 200.

${ }^{184}$ Jastrow, Dictionary, 200.
} 
book of Genesis chapter 22. In this passage an angel (literally messenger) calls out to Abraham from heaven to halt the slaying of Isaac. Again we have the close proximity of heaven and earth displayed in the sounding off of a celestial voice. Biblical scholar Umberto Cassuto, in his commentary on Genesis 21, perceived that it was an angelic ("voice from heaven") that saved both of Abraham's sons: Ishmael ${ }^{185}$ and Isaac. ${ }^{186}$ In the Ishmael story, for example, the text says that God (Elohim) heard the voice of the young man, when in verse sixteen we read that Hagar, Ishmael's mother, lifted up her voice and wept. ${ }^{187}$ The reference to lifting of the voice is to Hagar but the text attributes God's response to the young boy. The text then states that it was the "messenger of God" (male'ach Elohim) who booms from heaven with words of assurance for him and his mother, speaking in the first person singular in declaring that God will bless Ishmael. ${ }^{188}$ Her eyes are then opened by God so that she sees a well in order to save her and her son's life. $^{189}$

Similarly, in the story of Isaac's binding, the text states that it is the "messenger of the LORD” (male'ach YHVH) who calls out, from heaven, to Abraham, to refrain from killing his son. On the verge of death, like his brother Ishmael, perhaps here too, it was Isaac's plea for help which signaled the deliverance. The implied messenger(s) in both

\footnotetext{
${ }^{185}$ Genesis 21:17.

${ }^{186}$ Nahum Sarna, JPS Commentary on Genesis, (Philadelphia: Jewish Publication Society, 1989).

${ }^{187}$ Genesis 21:16.

188 "I will make him a great nation.” Genesis 21:18.

${ }^{189}$ Genesis 21:19.
} 
stories seem to be watching what is transpiring and verbalize God's Will, as literally from the heavens. The identity of the messenger and of God seems to be blurred adding intrigue and drama to the narrative. Such perplexing details may be reflected in the cryptic character ascribed to the bat kol. Like in these Biblical stories, the identity of the bat kol, God, an angel, or both, is not explained.

That the "voice" of the angel emanates from the heavens is noteworthy, since it is from here that the bat kol typically comes forth. In fact, the story of Isaac's binding is later alluded to by the rabbis and here again we find the participation of the bat kol. ${ }^{190}$ In one of the Palestinian Targumim, which may be dated to the first couple of centuries CE, we find a retelling of the Isaac's binding (Akedah). Not surprisingly, before the Biblical text introduces the angel of the LORD in verse eleven, verse ten of the Targum includes a bat kol which declared, "Come, see two unique ones in my world. One sacrifices and one is being sacrificed; the one who sacrifices does not hold back, and the one who is being sacrificed stretches out his neck."191 After this parenthesis the angel of the LORD calls out to stop Abraham from slaying his son. Therefore, the angelic voice in the Abrahamic story appears to resemble the bat kol in many details of its manifestations. My rationale is that the Biblical text served as a precedent through which the rabbis subsequently

\footnotetext{
190 See Leviticus Rabbah 20, where a bat kol assuages Abraham's concern that his son, Isaac, was not worthy enough to be sacrificed. See also, B. Gittin 57b, where a mother loses seven of her sons and she alludes to Abraham's binding of Isaac.

${ }^{191}$ See Paul V.M. Flesher and Bruce Chilton, The Targums: A Critical Introduction (Waco, TX: Baylor University Press, 2011), 457-458.
} 
adopted and adapted the forms of revelation in their day for theological, moral, and or didactic purposes.

Another Biblical story which exhibits modes of divine communication reminiscent of the bat kol in oracular ${ }^{192}$ fashion, is Gideon's miraculous routing of the Midianites. ${ }^{193}$ God instructed Gideon to reduce his force to a meager three hundred men so as to stress through whose power the victory would take place, namely God's. One night as Gideon and his men encamped above the valley where the Midianites were, God instructs him to go down and overrun the enemy. However, in an interesting gesture by God, Gideon is offered a sign to confirm God's Word to him. He was instructed to go down to the camp with his servant and to listen to the words spoken there. Gideon takes the offer and the Biblical text recounts that upon descending, Gideon overheard one man sharing his dream to another who in turn offered its interpretation by saying, "This is nothing else but the sword of Gideon the son of Joash, a man of Israel! Into his hand God has delivered Midian and the whole camp.” ${ }^{194}$

In what is an ironic detail in the story, Gideon is afforded words of confirmation through the mouth of his own enemy! Here, we read how God ratified His Word in the most mysterious and random of means. It may not be surprising to discover that on a few occasions the rabbis entertain chance utterances as portents of the holy. In tractate Megillah 32a we read that R. Shefatiah said in the name of R. Yohanan, "Whence [from

\footnotetext{
192 Oracular: random words that are of divine origin that provide guidance or an answer of sorts.

193 Judges 7.

194 Judges 7:14.
} 
where] do we know that we may consult a bat kol? Because it is said [Isaiah 30:21]: And thine ears shall hear a word behind thee saying...”195 The context of the passage quoted from Isaiah addresses the return of the people to righteous living in light of their waywardness. Their teachers would no longer be hidden from them and they will receive instruction from an invisible speaker on the right path to walk in. ${ }^{196}$ Divine guidance/clarification through chance utterances are the common denominator between this Biblical passage and this rabbinic text.

Another Biblical war hero experienced similar instructions from God in order to secure a military triumph. The book of second Samuel recounts how God instructed David not to directly go up and confront the Philistines but rather to approach them from the rear, and to attack when he would hear, "the sound of marching in the tops of the mulberry trees, then you shall advance quickly. For then the LORD will go out before you to strike the camp of the Philistines.” ${ }^{197}$ Here, David is guided to execute a different tactic, one that included discerning the moment the sign was taking place, which as a result assured him of God delivering his enemy into his hands. David did as instructed and was successful. In both the stories, Gideon and David alike were afforded insight into the events that were about to ensue. Therefore, the stories do not exhibit a purely oracular quality to them. Neither character was in the dark as to the next step they should

\footnotetext{
195 Translation from Lieberman, Hellenism, 195.

${ }^{196}$ Isaiah 30:20.

$1972^{\text {nd }}$ Samuel 5:24.
} 
take. However, what is peculiar is the random manner in which they are offered tokens of confirmation.

Moreover, according to Saul Lieberman, the practice of consulting verses randomly uttered by children was most popular among the rabbis. ${ }^{198}$ There is a similar practice among other peoples in antiquity, like the Egyptians, who, according to Plutarch, ${ }^{199}$ thought that small children possessed prophetic ability especially, "when they are playing in the temples and happen to say things.”200 Furthermore, Lieberman, notes that several Greek writers witness to the validity of this medium. ${ }^{201}$ There is also evidence of Christians partaking in this method of "revelation" as demonstrated in the case of Antony who decided to become a monk upon entering a church and hearing Matthew 19:21 read out loud: “Jesus said to him, 'If you want to be perfect go, sell what you have and give to the poor, and you will have treasure in heaven; come, and follow me." "202 Lieberman noted the phrase, found in both Talmudim, ${ }^{203}$ "they were wont

\footnotetext{
${ }^{198}$ See B. Hagigah 15a ff.; Gittin 68a; Esther Rabbah (to Esther 3:19).

${ }^{199}$ A Platonist philosopher of the first century CE.

${ }^{200}$ Is. et Osir. 14, 356e; cf. Lieberman, Hellenism, 196.

${ }^{201}$ Lieberman quotes Pausanias (lived second century CE) who in describing the oracle of Hermes in Phrae recounted: "He who wants to inquire from the god whispers his question in the ear of the god. Then he stops his own ears and leaves the market place. When he is gone a little way outside, he takes his hands from his ears and whatever words he hears he regards as an oracle.” Cf. Pausanias 9.11.5; Saul Lieberman, Hellenism in Jewish Palestine, (New York: JTS, 1950), 197.

${ }^{202}$ Athanasius, vita S. Antonii 2, PG xxvi, 841c. Another example cited is Augustine, in which he is directed to read the Scripture (i.e., Paul's epistle) by the chance utterance of children; Confessions, VIII.12.29; see Lieberman, Hellenism, 197.

${ }^{203}$ B. Sotah 48b; J. Sotah 9:14, 24b.
} 
[inclined] to make use of the bat kol"204 as further corroboration of its oracular purpose.

He views the Hebrew syntax as unusual and infers that it may be a translation from the Greek word kheresthai ${ }^{205}$ which means "to make use of" or "consult," such as in the case of an oracle. ${ }^{206}$ It should be noted that the Gideon and David stories are representative of uncommon forms of revelation in the Bible, hence Lieberman's interpretation finds greater resonance with Greek oracular practices.

The Hebrew Bible is explicit in its rejection of divination. ${ }^{207}$ Nevertheless, there were cases in which illegitimate means of knowledge were permitted in the Biblical narrative. ${ }^{208}$ In addition, it is clear that any illegal means of divination that were successfully consulted, were permitted by God for special purposes. ${ }^{209}$ Nevertheless, it

\footnotetext{
204 The phrase is בבת קול היו משתמשין. He notes that this phrase also occurs in B. Megillah 25b and that in Genesis Rabbah the object being used is the Holy Spirit rather than the bat kol. Translation by Lieberman, see Saul Lieberman, Hellenism in Jewish Palestine, (New York: JTS, 1950), 195.

${ }^{205} \chi \rho \tilde{\eta} \sigma \theta \alpha \mathrm{l}-w h i c h$ means "use” to make use of.” Cf. Barclay Newman, A Concise Greek-English

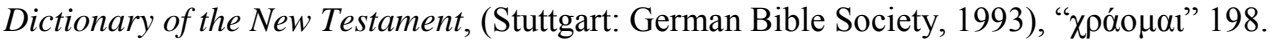

${ }^{206}$ Lieberman, Hellenism, 195.

${ }^{207}$ The primary passage prohibiting such practices is Deuteronomy 18:9-12. "When you come into the land which the LORD your God is giving you, you shall not learn to follow the abominations of those nations. There shall not be found among you anyone who makes his son or his daughter pass through the fire, or one who practices witchcraft, or a soothsayer, or one who interprets omens, or a sorcerer, or one who conjures spells, or a medium, or a spiritist, or one who calls up the dead. For all who do these things are an abomination to the LORD, and because of these abominations the LORD your God drives them out from before you."

${ }^{208}$ Including the previously mentioned example of Gideon receiving a sign through chance utterances, under God's direction. And the famous case of Saul consulting a medium at Endor in 1 Samuel 28.

${ }^{209}$ James Vanderkam wrote, “The prophetic opposition to pagan divination show, strangely, that Israel’s religious thinkers accepted the fundamental tenet of the mantic arts; through communication with the deity, the future can be known. This is the central point: it is not the presuppositions of divination that prophetic writers oppose; rather, it was the improper, idolatrous religious system within which such divining occurred." James Vanderkam, Enoch and the Growth of an Apocalyptic Tradition (Washington D.C.: Catholic Bible Assoc. of America, 1984), 73.
} 
appears that for many communities in antiquity, particularly Jews and Christians, chance utterances were considered acceptable means for receiving divine messages. Lieberman observed that the rabbis viewed chance utterances actually as a heavenly sign ${ }^{210}$ which in turn acted like a form of prophecy. ${ }^{211}$

I have briefly reviewed a selection of Scriptural passages that seem most salient to the concept of the bat kol, an unidentifiable speaker, sometimes from heaven, randomly intervenes in a story with an important message for an individual. There are other Biblical passages that could be expounded to draw out parallels with the bat kol; however, the examples provided in this section contain greatest similitude. ${ }^{212}$ In summary, concerning the Biblical texts, the Hebrew word for voice (kol) came to signify, more than a mere noise, namely the revelation of God. Betz summarizes the concept of "voice" as follows: "In distinction from the naive mythological speech of God, when $\mathrm{He}$ addressed Himself like a man to the patriarchs, Moses and Joshua, the word ip ( $k o l)$ points to the superhuman and numinous power of the divine revelation..."213 Thus, according to Betz, kol came to signify revelation of the most mysterious and sublime. Suffice it to say that the world of the rabbis, as made explicit in their commentaries, was replete with allusions and metaphors of the Biblical text. They were exceedingly

\footnotetext{
אות , אות

${ }^{211}$ He cites B. Chullin 95b; J. Sh. 6:9, 8c; cf. Lieberman, Hellenism, 197.

212 Texts like Psalm 147: 15 which reads: "He sends out His command to the earth; his word runs swiftly," see footnote 48. And Psalm 103:20: "Bless the LORD, you His angels, who excel in strength, who do his word, heeding to the voice of his word."

${ }^{213}$ Kittel et al., Theological, 282.
} 
proficient in the text, capable of explaining the most anomalous of phrases or peculiar of sentences with creative and insightful interpretations and or commentaries.

\section{B. Apocalypticism:}

The Dead Sea scrolls were an important discovery for better understanding the wider beliefs and practices of the Second Temple period. This was a community heavilyapocalyptic in orientation as attested by the works found in numerous caves near their compound on the northwestern shore of the Dead Sea. This group, presumed they were living the days prophesied by the Biblical prophets, prior to God meting out justice and redeeming the righteous of Israel. This group undoubtedly picked up on the Deuteronomistic expression, "listen to the voice of the LORD."214 In what is known as the War Scroll, the true Israel are called, "hearers of the divine voice." 215 Similarly the sect considered obedience to Torah as, "hearkening to the voice of the teacher of righteousness." ${ }^{216}$ Hence, God's original voice at Mt. Sinai, in some way, continues to echo through the annals of time via the written Scriptures and their interpretations. Subsequently, the expositors of the Biblical text become the conduit of the divine voice, and thus, those who adhere to such teachings fulfill the call to hearken to the voice of the LORD. Consequently, we begin to view the theological importance ascribed to God's voice, at least in one sect, of the late-Second Temple period.

\footnotetext{
${ }^{214}$ See Exodus 19:5; Deut. 4:30, 8:20, 13:18, 15:5, 26:14; Psalm 95:7.

${ }^{215} 1$ QM 10:10f. Cf. Kittel et al., Theological, 286.

${ }^{216} 1$ QH fr. 20:32 (9:53), 20:28 (9:50); Kittel et al., Theological, 286.
} 
In addition, they enacted meals which rehearsed the great Messianic banquet in which they anticipated partaking. Furthermore, discovered with the agglomeration of Biblical scrolls, were non-Biblical writings known as Apocrypha. ${ }^{217}$ One prominent apocalyptic work, which I will discuss in more detail, was the book of 4 Ezra (2 Esdras: 3-14). Lawrence Schiffman, in his book From Text to Tradition expounds on the genre of apocalyptic as, “...books which present revelations in a narrative framework in which an otherworldly being discloses mysteries to a human being. These revelations usually concern both eschatological salvation and a supernatural world.”218 Naturally, challenging social, economic, and even religious periods may have fomented the eschatological expectations reflected in apocalyptic literature. I suggest the "voices from heaven" of this genre are worth noting due to factors, such as their proximity in geographical location and time to the rabbis as well as important shared themes between the two collection of writings; like dealing with issues of suffering and the reward of the righteous and the wicked. However, there are noticeable differences as well; voices in apocalyptic writings typically manifest in heaven while the bat kol does so on earth.

The following section will be an overview of selected apocalyptic texts as they depict the imagery of voices resounding from heaven. The word apocalypse comes from the Greek word $\alpha \pi \circ \alpha \lambda \hat{v} \pi \tau \omega$ (apokalupto) meaning “to uncover" or "to reveal.”"19 It was

\footnotetext{
217 The "Apocrypha” (pl. of "Apocryphon”) means "hidden books" and are known in Catholic Bibles as the "deuterocanonical books." These works include the books of: Tobit, Judith, 1 and 2 Maccabees, Wisdom of Solomon, Ecclesiasticus, and Baruch. Cf. Martin Abegg, Jr. et al., The Dead Sea Scrolls Bible (San Francisco: HarperOne, 1999), viii.

${ }^{218}$ Lawrence Schiffman, From Text to Tradition (Hoboken: Ktav Publishing, 1991), 120.

${ }^{219}$ Newman, Greek-English, 21.
} 
typically not used in antiquity as a designation for certain types of texts. ${ }^{220}$ However, scholars, particularly beginning in the nineteenth century ${ }^{221}$ have identified several clusters of traits which many of these works share in common, ${ }^{222}$ chiefly, a narrative retelling of a heavenly ascent mediated by an angel or otherworldly being. ${ }^{223}$ Moreover, according to Daniel Harlow, heavenly ascents were employed in Hellenistic Judaism for the purposes of resolving theodicy ${ }^{224}$ in the wake of several tragedies. ${ }^{225}$ This is a major theme for several major apocalyptic texts.

A few commonly known (Jewish) texts include: Daniel, 1 Enoch, 4 Ezra, and the Sibylline Oracles. ${ }^{226}$ Some of its predominant themes include the problem of evil in the world, reward and punishment after death, the heavenly Temple, and the divine throne room. ${ }^{227}$ Though he does not expound, D.S. Russell opined that every reference to

${ }^{220}$ One notable exception is found in Revelation 1:1 where it reads, "The Revelation of Jesus Christ...”

${ }^{221}$ The label began to be widely accepted by scholars beginning with Friederich Lücke's comprehensive study on the subject in 1832; cf. John Collins, The Apocalyptic Imagination: An Introduction to Jewish Apocalyptic Literature (Grand Rapids: Eerdmans, 1998), 2-3.

${ }^{222}$ John Collins notes that prior to the rise of Christianity works were not catalogued as "apocalyptic" in antiquity. The first work to be recognized as apokalypsis (Greek "revelation") was the book of Revelation of the New Testament, though it is unclear what exactly was meant by the designation; cf. Collins, The Apocalyptic, 3.

${ }^{223}$ There are two primary categories of apocalypse: "Historical” in which history is reviewed and "otherworldly" in which the purported writer is caught up in a heavenly vision. Cf. Daniel Harlow, The Greek Apocalypse of Baruch, (New York: EJ Brill, 1996), 11.

${ }^{224}$ This refers to the issue of God allowing suffering to exist.

${ }^{225}$ Daniel Harlow has noted that, "In Hellenistic Judaism the otherworldly journey provided a narrative framework for dealing with the problem of theodicy in the aftermath of crises. Cf. Daniel C. Harlow, The Greek Apocalypse of Baruch, (New York: EJ Brill, 1996), 1.

${ }^{226}$ Other works that were published in the later part of the nineteenth century include: 2 and 3 Baruch, 2 Enoch, the Apocalypse of Abraham, and the Testament of Abraham; cf. Collins, The Apocalyptic, 3. Notable Christian works include John's Revelation (NT) and Hermas, Collins, The Apocalyptic, 6, n.16.

${ }^{227}$ Martha Himmelfarb, The Apocalypse: A Brief History, (Chichester: Wiley-Blackwell, 2010), 2. 
heavenly voices in apocalyptic literature is the rabbinic bat kol. ${ }^{228}$ One could infer that factors like same geographical location and time period could have contributed to the similarities in terminology and leitmotifs. My intention here is to draw out common themes and descriptive language so as to corroborate the view that apocalyptic literature bore influence upon the rabbis.

The texts to be consulted will be the pseudepigrapha ${ }^{229}$ of 2 (Syriac) Baruch, 3 (Greek) Baruch, and 4 Ezra. Louis Ginzberg was of the persuasion that the rabbis were completely opposed to apocalyptic literature. Essentially he argued that apocalyptists were raptured with another world which was deeply contrary to the prerogative of the rabbis, their primary focus was on preserving and fostering their way of life. The sages viewed themselves as guardians of the nation of Israel who knew all too well the deceits and rhetoric of charismatic visionaries. ${ }^{230}$ However, according to Robert Kirschner, the relationship is not as estranged as Ginzberg argued. Kirschner claims it is now widely assumed that two apocalypses (2 Baruch and 4 Ezra) originated in Tannaitic circles. ${ }^{231}$ Also, a later Midrashic collection known as Pesiqta Rabbati, appears to draw directly

\footnotetext{
${ }^{228}$ He also notes that voices from heaven were known to the Greeks; cf. D.S. Russell, The Method and Message of the Jewish Apocalyptic: 200 BC-AD 100, (Philadelphia: The Westminster Press, 1964$), 164$.

229 This was a widespread practice in the ancient world where a literary work is attributed to another person so as to give that work more credential.

${ }^{230}$ Louis Ginzberg, Some Observations on the Attitude of the Synagogue towards the ApocalypticEschatological Writings, JBL 41 (1922) 115-136, esp. 131, 134. The failed rebellion of Simon "bar Kocbha" ("son of the star") in 135 CE, a self-proclaimed messiah and military ruler, surely would have contributed to the conservatism of the rabbis.

${ }^{231}$ Other scholars consider 2 Baruch and 4 Ezra to have originated in Tannaitic times rather than the assumption to have been produced by actual Tannaim.
} 
from 2 Baruch. And lastly, the mystical tradition of early Judaism which produced the Hekhalot literature has obvious connections with Jewish apocalypticism. ${ }^{232}$ Therefore, to suggest no connection between the two seems far-fetched, nevertheless, it is maintained by scholars that the two were fundamentally different in scope and purpose.

Both 3 Baruch and 4 Ezra are dated to sometime after the destruction of the Temple in 70 CE and both are believed to derive from the land of Israel. ${ }^{233}$ Scholars have suggested that these works represent a type of lamentation genre. However, as Kirschner pointed out in his article, Apocalyptic and Rabbinic Responses to the Destruction of 70, a more pronounced theme is national calamity. ${ }^{234}$ Through their writings, the rabbis assuage the suffering experienced in the tragic events of the destruction of the Temple; they emphasized God's enduring love and selection of the Jewish people. This observation is echoed by Y.M. Grintz who wrote, "The nearness of God is the predominating idea of the Talmud and Midrash. God mourns because of the evil decrees He has pronounced upon Israel; He goes into exile with his children; he...is overjoyed if scholars triumph over him Halacha.”235 Thus, the rabbis conceived of God as empathizing with their pain and strife and not as having abandoned them.

\footnotetext{
${ }^{232}$ See Robert Kirschner in, Apocalyptic and Rabbinic Responses to the Destruction of 70, (The Harvard Theological Review, 2nd ser., 78, no. 1, 1985), 31.

${ }^{233}$ Kirschner notes that besides Josephus’ Jewish Wars and the Gospel of Matthew, the only other Jewish texts that we have after the destruction of the Temple are 2 (Syriac) Baruch, 3 (Greek) Baruch, 4 Ezra, and the Apocalypse of Abraham; none survived in its original tongue and the congruence between 2 Baruch and 4 Ezra has been long been noted by scholars. See Robert Kirschner in, Apocalyptic and Rabbinic Responses to the Destruction of 70, (The Harvard Theological Review, 2nd ser., 78, no. 1, 1985), 28.

${ }^{234}$ Kirschner, Apocalyptic, 29.

${ }^{235}$ Y.M. Grintz, God in Talmudic Literature, (Ency.Jud, 7.) 656-657. Quoted by Kirschner, Apocalyptic, 44-45.
} 
This is where Haggadah becomes instrumental in portraying God as an inherent part of daily life. As Ernest Trattner expressed it: "The problem was how to bring the reality of God closer to the warmth of the human heart...it was the 'story' based upon the Bible which supplied the need. The sages kept God close to the people by folkloristic transformation through the medium of the Haggadah." 236 Despite the fact that the Temple lay in ruins and His people exiled, God had not abandoned His people and would one day bring a much needed redemption; so it was espoused by the rabbis.

The Greek text of 3 Baruch is preserved in Christian manuscripts. ${ }^{237}$ It contains several instances of heavenly voices speaking to Baruch, the amanuensis of the Biblical prophet Jeremiah. The following passage depicts what happens when God speaks:

And as He [God] was speaking, there was thunder - like a sound of thunder - and the place in which we stood was shaken. And I asked the angel, 'My lord, what is this voice?' And my angel said, 'Now the angels are opening the 365 gates of heaven, and light is being separated from darkness.' And a voice came saying, 'Light-giver, give splendor to the world!' $(6: 13-14){ }^{238}$

Later in the book, in what is known as the fifth-heaven scene, the dramatic imagery of mysterious heavenly voices resound during Baruch’s celestial tour:

And there was a great voice like thunder. And I said, 'Lord what is this voice?' And he said to me, 'Now Michael is descending to receive the prayers of human beings.' And behold, there was a voice, 'Let the gates be opened!' And they opened, and there was a shriek like thunder... (11:3-5). ${ }^{239}$

\footnotetext{
The Greek, 4-5.

2383 Baruch 6:13-14. Translation from Harlow, The Greek, 54.

${ }^{239}$ Harlow, The Greek, 54.
}

${ }^{236}$ Ernest Trattner, Understanding the Talmud, (New York: Thomas Nelson, 1955), 91.

${ }^{237}$ It is thought to date to the late first century and early second century CE and is in the wider Jewish context of the destruction of the Temple. Cf. Harlow, The Greek, 10. Harlow is of the persuasion that it should be considered a Jewish work and that any Christian elements are later interpolations. Cf. Harlow, 
And at that time Michael departed, and the doors were closed. And there was a voice like thunder. And I asked the angel, 'What is this voice?' And he said to me, 'Now Michael is offering the virtues of human beings to God' (14:1-2). ${ }^{240}$

The references to a voice and thunder are repeated in each of the above mentioned passages. It is interesting to note that many Biblical texts employ descriptive phrases like "thunder" ${ }^{241}$ or "many waters" when using the Hebrew kol; ${ }^{242}$ this may signal from where the language is derived. Perhaps the noise (thunder) heard by Baruch included some intelligible communication as it prompts him, in every passage, to inquire concerning its purposes. Each incident of thunder and or noise precedes an event. The identity of the speaker here again is anonymous; the speaker could potentially be God or an angel. Still, as Daniel Harlow noted, these enigmatic voices heighten the anticipation of a visible manifestation of God's glory. ${ }^{243}$

The Apocalypse of Abraham is another apocalyptic work of the Second Temple period. ${ }^{244}$ This work addresses the evils of idolatry, and also makes use of heavenly voices. God is introduced in the story as calling out to Abraham via a voice that issued down from heaven in the semblance of a stream of fire (8:1-2). ${ }^{245}$ Further in the work,

\footnotetext{
${ }^{240}$ Harlow, The Greek, 54.

${ }^{241}$ See Exodus 9:23, 29, 33f; 19:16. A peculiar verse is Exodus 20:18 where the people literally saw (ro'im) the voices or thundering (kolot).

${ }^{242}$ Sometimes it refers to God’s voice: cf. Amos 1:2; Isaiah 29:6; 30:30f; Psalm 29.

${ }^{243}$ Harlow, The Greek, 54.

${ }^{244}$ This work is in Slavonic but it is thought to have been translated from Greek with hints of the original being in Hebrew or Aramaic. It shares with 4 Ezra and 2 Baruch and 3 Baruch provenance from the land of Israel and it too has the destruction of the Temple as its main event, indicative of a probable late-first century CE composition. This work also has parallels with later Midrashim: Genesis Rabbah 38:19 (on Gen. 11:28), Tanna debe Eliyahu 2:25. Cf. Collins, The Apocalyptic, 225.

245 The book is 32 chapters long and Abraham hears “a voice” normally referring to God on some twenty occasions.
} 
Abraham describes the voice of God coming to him out of the midst of fire; "a voice of many waters, like the sea in its uproar.” $(17: 1)^{246}$ In the Bible we also find examples of the voice of God as part and parcel of intense manifestations of His presence. ${ }^{247}$

In comparing the heavenly voices in 3 Baruch and the Apocalypse of Abraham, Daniel Harlow writes, “In one, the divine 'voice' that opens the heavens grants a theophany; in the other, the 'voice' that opens the gates of heaven remains hidden.” Abraham is given a theophany of sorts through a potent and resonating voice, while in 3 Baruch the voice harps anonymously; marking the onslaught of various events in the heavenly terrain.

4 Ezra (i.e. 2 Esdras: 3-14) is another important apocalyptic work considered by scholars to be from around the late-first century CE. ${ }^{248}$ This work exhibits one of the classic characteristics of an apocalyptic text; namely the disclosing of the secrets of the eschaton when the Messiah will destroy evildoers, to Ezra. ${ }^{249}$ Accordingly, it is God's judgment and not His mercy which predominates in this work. ${ }^{250}$ At one point, Ezra seeks to understand the calamity that has befallen his people (i.e. the destruction of the

\footnotetext{
${ }^{246}$ See Ezekiel 1:26, 28. Harlow, The Greek, 55.

${ }^{247}$ God's revealing to the people of Israel at Mt. Sinai (Exodus 19:16-20; 20:18-21) was where the people saw kolot ("voices" or "thundering") and heard the strong trumpet sound ("kol") causing all the people to tremble. Cf. Kittel et al., Theological, 283.

${ }^{248}$ And also from the land of Israel.

${ }^{249}$ Or "end of days." Lawrence Schiffman wrote of it as being the only "true" apocalyptic text found in the apocrypha of the Dead Sea Scrolls; cf. Schiffman, From Text, 126.

${ }^{250}$ Kirschner, Apocalyptic, 39.
} 
Temple in Jerusalem); ${ }^{251}$ he is met with questions too lofty for his understanding, in turn pointing to his own ignorance and short-sightedness. ${ }^{252}$ John Collins has observed that both 4 Ezra and 2 Baruch $^{253}$ draw heavily from theological traditions that are close to rabbinic Judaism, in that both devote little attention to the heavenly world, they are averse to calculations of the end of time, they bear the influence of historical events, and they are flexible in incorporating diverse theological views. ${ }^{254}$ Such traditions or themes found their way both into apocalyptic and rabbinic writings. The rabbis could have potentially drawn imagery and motifs from apocalyptic sources that would have spoken to them and or their audience.

Here again (as in the Apocalypse of Abraham), the description of God's voice as "the sound of many waters" is employed; a phrase found in both Ezekiel and the book of Revelation. ${ }^{255}$ Similarly, in chapter thirteen of 4 Ezra, Ezra sees a man emerge from the sea flying with the clouds. Wherever the sound of his voice reaches, everything melts like hot wax, ${ }^{256}$ and when multitudes come to war against him he defeats them all with a

\footnotetext{
${ }^{251}$ Josephus records that "a voice” was heard in the Temple, prior to its destruction; cf. Jewish War 6: 299300. Quoted in R.J. Coggins and Michael A. Knibb, The First and Second Books of Esdras (Cambridge: Cambridge University Press, 1979), 133.

${ }^{252}$ See 2 Esdras 5:31-40. Coggins and Knibb, The First and Second, 138-139.

${ }^{253}$ This work is in Syriac (a dialect in Aramaic) and is different than 3 Baruch.

${ }^{254}$ Collins, The Apocalyptic, 224-225.

${ }^{255}$ See 6:17. Knibb comments that this is the traditional language to describe the sound of God's voice (cf. Ezek. 43:2, Rev. 1:15). Cf. Coggins and Knibb, The First and Second, 150.

${ }^{256}$ Knibb comments that the simile of wax melting before fire is used in numerous places in the Hebrew Bible to describe God's self-revelation; cf. Psalm 97:5. Knibb, The First and Second, 258.
} 
torrent of fire that proceeds from this mouth. ${ }^{257}$ Also reminiscent of Apocalypse of Abraham is the imagery of a stream of fire; in which God was the speaker while in 4 Ezra it was a mysterious (Messianic?) individual with the appearance of a human. Other references to of heavenly voices are found in chapter eleven where a heavenly voice twice makes a parenthesis to Ezra's vision. ${ }^{258}$ Another passage that contains these voices occurs in chapter fourteen where twice Ezra is abruptly called by God. ${ }^{259}$ The text reads that Ezra was called from a bush. It seems that the story of Moses' calling is purposely invoked, and in doing so grants Ezra the status of "second Moses" of sorts who is called to restore the Scriptures. ${ }^{260}$

Therefore, a survey of a few apocalyptic works ${ }^{261}$ begins to shed light on the themes and structure of these mystical texts; ascent to the heavenly sphere entails encounters with supernal sights and sounds which the apocalyptist recounts. Sometimes God remains hidden in these stories, only intimated by the sound of a voice, while on other occasions His presence is more explicit and spectacular conferring upon the visitor

\footnotetext{
${ }^{257}$ See 13:4, 10. The imagery may be from Isaiah 11:4 where it reads, "He shall strike the earth with the rod of His mouth, and with the breath of His lips He shall slay the wicked."

${ }^{258}$ The text in 11: 10 reads, "You have ruled the world for so long; now listen to my message before your time comes to disappear. None of your successors will achieve a reign as long as yours, nor even half as long." 11:36 calls the attention of Ezra: "Then I heard a voice which said to me: 'Look carefully at what you see before you"”. Text from Coggins and Knibb, The First and Second, 238, 244.

${ }^{259}$ See 14:1, 38.

${ }^{260}$ In Exodus 3:4 when God saw that Moses turned to look God called to him, “Moses! Moses!”

${ }^{261}$ Other apocalyptic references include: Testament of Abraham, 10; Testament of Levi, 18:6, 2; Apocalypse of Baruch (2), 13:1, 22:1; The Story of Ahikar, 1:11.
} 
a sublime and terrifying vision. Heavenly voices are a present and important theme in the apocalyptic genre.

David Aune has noted that most scholars consider apocalyptic literature to actually be an offspring of Biblical prophecy. ${ }^{262}$ He upholds this view while maintaining that it was only one of several offspring of the Second Temple period. A distinguishing feature between the two genres was the formulaic introductions of the speaker. In Biblical prophecy, the prophet often introduced his oracle with a phrase akin to, “Thus says the LORD...” placing the weight of the message squarely on the divine. In apocalyptic literature the emphasis is placed upon the seer who testifies to the visions and messages that he or she has witnessed. ${ }^{263}$ Indeed, heavenly voices seem more appropriate to the visionary journeys rather than classical prophecy, as the voices serve to corroborate what is transpiring before the apocalyptist.

Furthermore, in my estimation, types of oracles, found both in Biblical prophecy and apocalyptic writings find analogous examples in the bat kol of the rabbis. One example is the "woe oracle." There are two overarching components to this type of oracle. One is the charge in which the misdeeds of the individual or people are addressed. Second is the pronouncement of the fate of the person being addressed (e.g. exile, death, etc.). The stories of King Nebuchadnezzar's judgment overviewed in this chapter fit with this type of oracle. Conversely, there are what Aune labels the "oracles

\footnotetext{
262 David Aune, Prophecy in Early Christianity and the Ancient Mediterranean World (Grand Rapids: Eerdmans, 1983), 114.

263 Aune, Prophecy, 115.
} 
of Assurance”, which were common in the Hebrew Bible and in Near Eastern prophetic speech. ${ }^{264}$ A basic structure can also be discerned: an exhortation of encouragement, and a reason for the individual to gain confidence; sometimes a final section can include a promise of sorts. ${ }^{265}$ In the following chapter I will cover more in detail the primary function(s) of the bat kol, but it should suffice for now to state that the manner the bat kol encourages individuals in dire circumstances, like in cases of martyrdom, is quite similar to the "oracle of assurance." Hence, a connection can be made not just in the presence of heavenly voices, but also in their respective functions.

\section{Greek Writings:}

Before proceeding with the Talmudic text, some remarks concerning Greek literature are appropriate in discussing works that share this common literary device. Hellenism's influence pervaded much of the ancient world at one time. Nevertheless, there were segments of Jews who repudiated aspects of this culture, in particular when injunctions were placed upon the Jewish people that were contrary to their prescribed ways of life. ${ }^{266}$ According to Otto Betz one of the meanings of the word $\varphi \omega v \eta$ (phoné) can be, "the utterance of a deity, the organ of the divine fiat by which the sun and stars were made.”267 This definition evokes comparison with concepts from the Biblical and

\footnotetext{
${ }^{264}$ These labels are from Aune’s discussion on apocalyptic literature; cf. Aune, Prophecy, 116-117.

${ }^{265}$ Aune, Prophecy, 117.

${ }^{266}$ The Maccabean revolt against one of Alexander's successors, the Seleucids, could be considered a case in point.

${ }^{267}$ See Execration Tablet of Hadrumetum, Audollent Def. Tab., 271, 23f ( ${ }^{\text {rd }}$ Century AD); cf. Kittel, Theological, 279.
} 
rabbinic corpora in which the divine voice is an agent of creation and or God's will. Thus one Hellenistic understanding seems to underscore the role of agents revealing divine words. Hellenistic legends similarly portray Zeus’s voice as thunderous causing dread to those who hear it. ${ }^{268}$ Socrates appeals to God's voice as a directive force. ${ }^{269}$ Other ancient Near Eastern and Greek texts point to legislation being derived from a divine voice. $^{270}$

Another interesting detail attested to in Greek and Roman writings are how supernatural voices allegedly occurred in temples. ${ }^{271}$ The Roman historian and politician, Tacitus (ca. 56-120 CE), also narrates how certain Jews interpreted prodigies as portents that were indicative that their time to rule had come. One of the signs that occurred in the Temple was a superhuman voice that declared, “'The gods are departing;' at the same moment the mighty stir of their going was heard.”272 This imagery also occurs several times in the book of John's Revelation. ${ }^{273}$

\footnotetext{
${ }^{268}$ Luc. Icaromenipp., 23; Kittel et al., Theological, 279.

${ }^{269}$ Plat. Ap., 31d. Betz notes that this was contrary to popular opinion concerning oracles; “According to Socrates God speaks to the individual who apart from external criteria and alien authorities must himself decide whether he will understand and obey the voice of conscience as the voice of God.” Kittel et al., Theological, 280.

${ }^{270}$ Kittel et al., Theological, 280.

${ }^{271}$ Another source says that at the birth of Osiris a mysterious voice declared that the Lord of all was manifested; Plut. Is. et Os. 12 (II, 355e), cf. Kittel et al., Theological, 279.

${ }^{272}$ See Histories 5.13.1-2; translation by Louis Feldman and Meyer Reinhold, Jewish Life and Thought among Greek and Romans: Primary Readings, (Minneapolis: Fortress Press, 1996), 268.

${ }^{273}$ See Rev. 16:1, 17; 19:5; 21:3.
} 
Lastly, the Greek world upheld the belief in oracles. The term oracle comes from the Latin oraculum, "a thing spoken.”274 Jacob Howland remarked, "Greek oracles were notoriously ambiguous, and several famous legends spelled out the dire consequences for those who failed to inquire into their meaning. In fact, the admonition "Know Thyself" was inscribed in or on the Temple at Delphi, as if to underscore that an oracle from the Pythia was to be received as a provocation to thought, and especially to self-reflection. ${ }^{275}$ The purpose of the oracle included answering inquiries and offering predictions of the future. $^{276}$

D. Josephus:

Josephus and both the Jerusalem and Babylonian Talmudim, attest to the same heavenly voice that emanated from inside the Temple in Jerusalem to communicate to the Hasmonean king and priest John Hyrcanus that a military victory was won by his

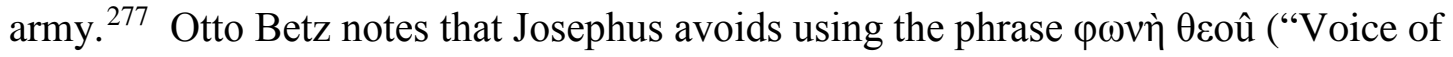

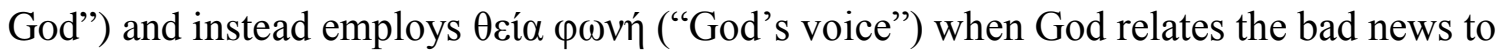
Abraham that Israel will become slaves in Egypt. ${ }^{278}$ The reason behind this could be an emphasis of God's transcendence rather than His immanence. Therefore the phrase

\footnotetext{
${ }^{274}$ Which then comes from two Greek words, chresmos (comes from chrao "to proclaim”) and chresterion (from chraomai "to enquire of an oracle." Cf. Richard Stoneman, The Ancient Oracles: Making the Gods Speak (New Haven, CT: Yale University Press, 2011), 13.

275 Jacob Howland, Plato and the Talmud (Cambridge: Cambridge University Press, 2011), 113-114.

${ }^{276}$ Richard Stoneman, The Ancient Oracles: Making the Gods Speak (New Haven, CT: Yale University Press, 2011), 11.

${ }^{277}$ See Josephus (Antq. XIII 10.3) and T. Sotah 13:5; J. Sotah 24b; B. Sotah 33a.

${ }^{278}$ Ant., 1, 185, cf. Gen. 15:13; cf. Kittel et al., Theological, 290.
} 
“God's voice”, lends itself for interpretation, but implies God is not explicitly manifest, rather, He communicates through the agency of messengers. In this same vein, Josephus also interprets God's call to Moses from the burning bush as, "an act of fire that found a voice and used words."279

Betz suspects that in the overlap between Josephus and rabbinic texts that recount the voice from heaven to John Hyrcanus, that the former may have been influenced by the latter. ${ }^{280}$ In B. Sotah 33a we read that while John Hyrcanus was in the Temple, from the Holy of Holies a bat kol came forth and said, "The young men [i.e., your children] have won the battle against Antioch.” Then the text recounts that Simon the righteous also heard a bat kol from the Holy of Holies which said, "Annulled is the decree set against the temple.” Interestingly enough, the commentators say that it was in Aramaic that the bat kol spoke. Earlier the passage remarks whether praying for one's needs is permitted in Aramaic, the common vernacular of that age. The examples of the bat kol speaking in Aramaic are used to support the notion that ministering angels comprehend Aramaic or even that the bat kol was actually the angel Gabriel. The account of John Hyrcanus is an interesting commonality with rabbinic texts; it is possible the story circulated among Pharisaical and or priestly circles since Josephus was a part of both groups.

Josephus also recounts the strange oracles of a Jesus son of Ananias. During the feast of Tabernacles at $62 \mathrm{CE}$ he began to peripatetically decry the coming destruction of

\footnotetext{
${ }^{279}$ Ant., 2, 267; cf. Kittel et al., Theological, 290.

${ }^{280}$ Kittel et al., Theological, 291.
} 
Jerusalem and the Temple. He wailed with the following phrase: “A voice from the east, a voice from the west, a voice from the four winds; a voice against Jerusalem and the sanctuary, a voice against the bridegroom and the bride, a voice against the people!"281 He was beaten and scourged by the authorities in order to bring him to his senses, but it was to no avail. Jesus did not relent from his message. For seven years and five months he persisted, until during Jerusalem's siege, he was killed by a stone catapulted by a Roman machine in 69 CE. The theme of supernatural voices echoing from or concerning temples finds attestation in multiple Greek and first century Jewish sources.

In summary, there is evidence that the Greeks also underscored the value of the voice of the gods for various reasons. Some of the functions appear similar to the functions employed in rabbinic literature and other writings from antiquity: endorsing individuals and divine messages protruding from temples. Nevertheless, a strong claim cannot be made here concerning their bearing on other literatures in this specific regard. Some of the sources cited date to the first couple of centuries CE. In such case, it is possible that they may have been the influenced rather than the influencer. That would require a more critical look at some specific cases from both Hellenistic and rabbinic sources. Yet the similarities, as with the other works reviewed in this chapter, are probably not happenchance; a more precise understanding of their relation needs to be explored. ${ }^{282}$

\footnotetext{
${ }^{281}$ As recounted by Josephus, War 6:300-309. Geza Vermes likened this oracle to the one pronounced by Jeremiah (cf. Jeremiah 7). Cf. Geza Vermes, Who's Who in the Age of Jesus, (London: Penguin Books, 2006), "Jesus son of Ananias."

${ }^{282}$ Louis Feldman considers the concept of a Jewish prophetess, a Sibyl foretelling the doom of an empire (i.e. Rome), to have been adopted by the Jews in the second century BCE in Egypt, from the pagan
} 


\section{Conclusion}

Many sources and their possible relation to the bat kol have been reviewed herein. The Biblical narrative provides striking similarities with the manner in which the bat kol is depicted in the Talmud. Most noteworthy are the examples from the book of Daniel and the voice from heaven during Hagar and Ishmael's wandering and Isaac's binding. Apocalyptic literature, considered to be an offspring of Biblical prophecy by some scholars, ${ }^{283}$ also makes use of heavenly voices to narrate heavenly activities, such as Michael descending to receive the prayers of people and then offering up their virtues to God and other angelic activities related to humanity. As Otto Betz summarized, “The apocalyptic view of God's voice is influenced on the one side by expectation of a new eschatological revelation and on the other by heightened awareness of the divine transcendence.”284 In my estimation, it is the stories from the Bible and apocalyptic literature from circa the Second Temple period that demonstrate the clearest correlations. This is due to several reasons. In the Biblical examples surveyed in this chapter the language describing the manifestation of the heavenly voices in both groups of writings is quite similar; from the verb describing its arrival to the heavenly location from where the voice is heard. Moreover, words of judgment are proffered in both. Apocalyptic literature also includes different types of oracles (e.g. woe and praise); such functions find correlation with rabbinic stories such as in instances of martyrdom or publicly

\footnotetext{
Sibylline Oracles; cf. Louis Feldman and Meyer Reinhold, Jewish Life and Thought Among the Greek and the Romans: Primary Readings, (Minneapolis: Fortress Press, 1996), 181.

${ }^{283}$ Whether or not apocalyptic writings originated in prophecy or wisdom literature remains debated.

${ }^{284}$ Kittel et al., Theological, 286.
} 
endorsing the piety of an individual. Hellenistic sources also exhibit similar themes: voices echoing from temples and endorsing or praising individuals.

The mysterious voices of revelation therein could be conceived to have been appropriated by the rabbis as an agent of comfort and encouragement in the wake of the painful destruction of the Temple. In other words, it may have been appealed to in order to assure the people that God was still involved in their everyday affairs. In addition, the anonymity of the speaker protects against possible heresies that may be derived from this messenger. In other words the rabbis may have attributed to this "voice" a less authoritative and generic label in order for it not to be automatically construed as the Holy Spirit or God's very voice. Hence, this may explain the reasoning behind the selection of the term bat (lit. daughter); although the bat kol is sometimes used interchangeably with God and or the Holy Spirit. In this fashion, it mimics the mystery of God's theophanies in the Biblical time period when at times God's messenger spoke in His very place and with His very authority. The following chapter will explore discernable categories within the text of the Babylonian Talmud. 


\section{CATEGORIES}

\section{Introduction}

Let us now turn our attention specifically to Talmudic stories portraying the bat kol. Despite my efforts to produce neat categories in which to effectively locate each of the narratives, many stories exhibit various details which make it difficult to tag with one of my suggested labels. In such cases, I based my decision on what appears to be the more dominant purpose for the voice from heaven while pointing to its versatility. Chief examples will be fleshed out so as to depict a discernable and recurring role for each type, including an analysis of its compositional structure, parallel versions if any, and other pertinent historical details. The five general categories are therefore: 1) entering the world to come, 2) praise towards individuals, 3) rebuke/judgement to individuals, 4) matters related to Halacha, and 5) a miscellaneous category. ${ }^{285}$

Furthermore, there are two general types of stories in regards to time: those retrojected into the Biblical period and those situated in the times of the rabbis. In addition, various stories depict the bat kol or narrator quoting Biblical verses. The examples provided in this chapter display several of the aforementioned characteristics. In analyzing these stories I will signal peculiar features, events/sayings, and recurring themes in addition to exploring social and historical factors underlying the text. ${ }^{286}$ Lastly, I will conclude by summarizing the findings of each category.

\footnotetext{
${ }^{285}$ The literature review highlighted S. Louis's use of categorical types; I am following his model here. See Society, Transactions, 182-194.

${ }^{286}$ As Richard Kalmin noted in his book The Sage in Jewish Society of Late Antiquity, "Rabbinic interpretations of Scripture were motivated not only by a desire to explicate the Biblical text but also by
} 
Before, expositing the first category I would like to draw the reader's attention to

a table (see Table 2) displaying how I catalogue all the references to the bat kol in the

Babylonian Talmud. Displayed are the categories and references along with a concise

description; repeated stories are joined together:

Table 2: Depicts categories of function along with reference and short description.

\begin{tabular}{|c|c|c|c|c|}
\hline World to come & $\begin{array}{l}\text { Praise towards } \\
\text { Individuals }\end{array}$ & $\begin{array}{c}\text { Stories of } \\
\text { rebuke/ } \\
\text { judgment }\end{array}$ & $\begin{array}{l}\text { (Related to) } \\
\text { Halacha }\end{array}$ & Miscellaneous \\
\hline $\begin{array}{l}\text { Ber. 61b-Akiva's } \\
\text { martyrdom. } \\
\text { Er. 54b-R. } \\
\text { Preida offered } \\
\text { four hundred } \\
\text { extra years of life } \\
\text { or life in the } \\
\text { world to come. } \\
\text { Ta. 29a-Roman } \\
\text { officer inherits } \\
\text { life in the world } \\
\text { to come by } \\
\text { saving Rabban } \\
\text { Gamaliel. } \\
\text { M.K. 9a-Israel is } \\
\text { prepared for life } \\
\text { in the world to } \\
\text { come. } \\
\text { Ket. 103b-Life in } \\
\text { wtc at Rebbi’s } \\
\text { death. } \\
\text { Ket. 104a-Rebbi } \\
\text { will have a } \\
\text { "resting place.” }\end{array}$ & $\begin{array}{l}\text { Ber.12b-Saul } \\
\text { affirmed as chosen of } \\
\text { the LORD. } \\
\text { Ber. 17b/Ta. } \\
\text { 24b/Chl. 86a- } \\
\text { Hanina b. Dosa } \\
\text { endorsed. } \\
\text { Sh.14b/Er. 21b- } \\
\text { Solomon introduces } \\
\text { washing of hands. } \\
\text { R.H. 21b-Moses } \\
\text { unique as a prophet. } \\
\text { Ta. 21b-Aram. Abba } \\
\text { the surgeon. } \\
\text { Ta. 25b-R. Akiva } \\
\text { answered for rain. } \\
\text { M.K. 16b-David was } \\
\text { righteous except for } \\
\text { one thing. } \\
\text { So. 10b-Judah's } \\
\text { merit in confessing } \\
\text { his failing before } \\
\text { Tamar. }\end{array}$ & $\begin{array}{l}\text { Ber. 3a-Temple } \\
\text { destroyed } \\
\text { because the sins } \\
\text { of the people. } \\
\text { Sh.33b-Simeon } \\
\text { and Elazar } \\
\text { sentenced to } \\
\text { hide in a cave } \\
\text { for } 12 \text { years. } \\
\text { Sh. 56b- } \\
\text { Mephiboseth } \\
\text { rebuked. } \\
\text { Sh. 149b- Neb. } \\
\text { in Gehinom } \\
\text { (Hell). } \\
\text { Pe. 94a/Chag. } \\
\text { 13a- Neb. } \\
\text { Rebuked. } \\
\text { Yo. 9b-Holy } \\
\text { Spirit departed } \\
\text { from Israel. } \\
\text { Yo. 22b- } \\
\text { Solomon } \\
\text { reprimanded. }\end{array}$ & $\begin{array}{l}\text { 287*Ber. 51b/Pe. } \\
\text { 114a-Priority over } \\
\text { blessing first the } \\
\text { day or wine. } \\
\text { *Er. 6b-Dispute } \\
\text { over public roads. } \\
\text { Er. 13b-Hillel and } \\
\text { Shammai original } \\
\text { debate. } \\
\text { *Yev. 14a- } \\
\text { Different views on } \\
\text { Levirite marriage. } \\
\text { Yev. 122a-Hillel } \\
\text { permits a woman } \\
\text { to remarry on the } \\
\text { basis of a bat kol. } \\
\text { B.M. 59b-Aknai } \\
\text { incident/Eliezer vs. } \\
\text { Sages. } \\
\text { *Chl. 44a- } \\
\text { Contradiction of } \\
\text { opinion } \\
\text { concerning treife } \\
\text { meat. }\end{array}$ & $\begin{array}{l}\text { Sh. 88a-Bat kol } \\
\text { appeared when } \\
\text { Israel said "we will } \\
\text { do." } \\
\text { Meg. 3a-God's } \\
\text { secrets not to be } \\
\text { disclosed. } \\
\text { Meg. 32a- } \\
\text { Justification using } \\
\text { the bat kol. } \\
\text { M.K. 18b/So. 2a/Sa. } \\
\text { 22a-Preordained } \\
\text { marriages } \\
\text { announced. } \\
\text { Chg. 14b- Four } \\
\text { sages are called up } \\
\text { go up to heaven by a } \\
\text { bat kol. } \\
\text { Ket. 77b-Sage } \\
\text { hoodwinks angel of } \\
\text { death. }\end{array}$ \\
\hline
\end{tabular}

social, cultural, religious, polemical, and/or apologetic concerns.” Richard Kalmin, The Sage in Jewish Society of Late Antiquity (New York: Routledge, 1999), 15.

${ }^{287}$ The * is indicative of stories that allude to the famous halakhic debate between the schools of Shammai and Hillel; cf. B. Eruvin 13b. Highlighted text represents stories pertaining to Biblical times and or characters: 24 stories total. 


\begin{tabular}{|c|c|c|c|c|}
\hline $\begin{array}{l}\text { Git. 57b-Mother } \\
\text { loses her seven } \\
\text { sons. } \\
\text { B.B. 74b- Bat kol } \\
\text { that a certain } \\
\text { chest with } \\
\text { precious stones in } \\
\text { it is reserved for } \\
\text { the righteous of } \\
\text { the wtc. } \\
\text { Sa. 104b-David } \\
\text { defends } \\
\text { Solomon's right } \\
\text { to enter the world } \\
\text { to come. } \\
\text { A.Z. 10b-Roman } \\
\text { officer, Ketiah b. } \\
\text { Shallum. } \\
\text { A.Z. 17a-Sinner, } \\
\text { Elezar b. Durdia, } \\
\text { is accepted upon } \\
\text { repenting before } \\
\text { his death. } \\
\text { A.Z. 18a- } \\
\text { Chanina b. } \\
\text { Teradyon and his } \\
\text { executioner enter } \\
\text { world to come. }\end{array}$ & $\begin{array}{l}\text { So. 13b-Moses } \\
\text { lauded at his death. } \\
\text { So. 48b/Sa. 11a- } \\
\text { Hillel/Samuel the } \\
\text { Small worthy of } \\
\text { Shechinah. } \\
\text { B.M. 85a-R. Elazar } \\
\text { buried w/ his father } \\
\text { due to the discomfort } \\
\text { he experienced in } \\
\text { life. } \\
\text { B.M. 86a-R. bar } \\
\text { Nachmani dies with } \\
\text { the word "pure.” } \\
\text { Sa. 39b-Ovadiahu } \\
\text { feared the LORD. }\end{array}$ & $\begin{array}{l}\text { Meg. 12a- } \\
\text { Belshazar is } \\
\text { addressed. } \\
\text { Chg. 15a-Elisha } \\
\text { b. Avuyah told } \\
\text { not to repent. } \\
\text { Git. 56b-Titus } \\
\text { challenged. } \\
\text { B.M. 85b-R. } \\
\text { Yose not buried } \\
\text { with his father. } \\
\text { Sa. 96b- } \\
\text { Nebuzaradan } \\
\text { encouraged to } \\
\text { destroy the First } \\
\text { Temple. } \\
\text { Sa. 102a-Ten } \\
\text { tribes castigated } \\
\text { for not } \\
\text { following } \\
\text { David. }\end{array}$ & $\begin{array}{l}\text { Chl. 87a-Birkat } \\
\text { hamazon } \\
\text { ("blessing after the } \\
\text { meal”). }\end{array}$ & $\begin{array}{l}\text { So. 21a- Hillel } \\
\text { refused to share } \\
\text { merit of Torah study } \\
\text { with his brother. } \\
\text { So. 33a-Military } \\
\text { victory announced in } \\
\text { the Holy of Holies. } \\
\text { B.B. 3b-Herod kills } \\
\text { Hasmonean masters. } \\
\text { B.B. 58a-God } \\
\text { prohibits gazing } \\
\text { upon Adam (i.e., His } \\
\text { likeness). } \\
\text { B.B. 73b-Sages are } \\
\text { warned with an } \\
\text { extremely deep and } \\
\text { dangerous body of } \\
\text { water. } \\
\text { B.B. 74a-God } \\
\text { bemoans exiling the } \\
\text { people. } \\
\text { Sa. 94a-God's secret } \\
\text { in choosing who to } \\
\text { make the Messiah. } \\
\text { Hr. 12a/Ker.5b- } \\
\text { Moses and Aaron } \\
\text { did not illegally use } \\
\text { holy oil. } \\
\text { Mak. 23b-Divine } \\
\text { Spirit makes public } \\
\text { appearance in } \\
\text { Biblical history via a } \\
\text { bat kol. } \\
\text { Men. 53b-Israel will } \\
\text { be restored at the } \\
\text { end of their destiny. }\end{array}$ \\
\hline \multicolumn{5}{|l|}{ Totals: } \\
\hline 12 & 13 & 13 & 8 & 16 \\
\hline
\end{tabular}


The category with the least occurring examples are those related to Halacha, though it is noteworthy how numerous stories allude to a bat kol settling a famous legal stalemate between the schools of Shammai and Hillel. The Halacha ended up following Hillel. Nevertheless, on occasion, the rulings of Shammai are referenced and sometimes approved as valid, in such cases we read how the narrator remarks that one could argue that Shammai's ruling stood prior to the intervention of the bat kol. There are also twenty-four out of sixty-two stories which pertain to Biblical characters and or the Biblical period.

\section{A. The Talmud:}

The Talmud is written in a blend of Hebrew and Aramaic. Scholars like Jacob Neusner have detected the interchangeability of language within the Bavli as a marker of taxonomy. That is to say the redactors of the Bavli communicated on multiple levels: 1) explicitly, via the written text, and 2) implicitly in the language of choice of such communication. Hence, Neusner proposes whatever is said in Hebrew, "is represented as authoritative and formulates a normative thought or rule. What is said in Aramaic is analytical and commonly signals an argument and formulates a process of inquiry and criticism.”288 Menachem Fisch has similarly identified the importance of language in the Bavli. He noted that any material attributed to the Tannaim ${ }^{289}$ is quoted solely in

\footnotetext{
${ }^{288}$ Jacob Neusner, The Discourse of the Bavli: Language, Literature, and Symbolism (Atlanta: Scholars Press, 1991), 2.

${ }^{289}$ Tanna is Aramaic for "reciter of traditions;" cf. Schiffman, From Text, 178. Schiffman dates them from the Roman conquest of 63 BCE to the final editing of the Mishnah (ca.200 CE); cf. Schiffman, From Text, 111.
} 
Hebrew, while material quoted of the Amoraim ${ }^{290}$ is preserved in Aramaic. ${ }^{291}$ This editorial feature may suggest the "voice from heaven” originated with the Tannaim (midfirst BCE-third century CE) since the majority of references are in Hebrew (bat kol) and are also found in the Bavli. ${ }^{292}$ There are a total of seventy references, including nine repeated stories, to the Hebrew, bat kol, and the Aramaic, bat kala, in the Babylonian Talmud, and correspondingly, twenty-four in its Jerusalem counterpart. ${ }^{293}$ In short, it seems that the activity of the bat kol was first recorded during the time the sages were living in the land of Israel in the first couple of hundred years of the Common Era. ${ }^{294}$

The Jerusalem Talmud consists of laws pertaining to Jewish Palestine and its agriculture. ${ }^{295}$ According to Adin Steinsaltz, factors such as the economic instability of the Roman Empire, the rise of Christianity, contributed to the gradual decline of Jewish

\footnotetext{
290 "Talmudic sage after the Tannaitic until the final redaction of the Talmud (220-500 CE). The Amoraim interpreted the statements of the Tannaim and expanded upon them.” Adin Steinsaltz, Talmudic Images (Northvale, NJ: Jason Aronson, 1997), 157.

${ }^{291}$ Menachem Fisch, Rational Rabbis: Science and Talmudic Culture (Indianapolis: Indiana University Press, 1997), 114.

292 There are the five Aramaic references in the Targumim (cf. Targum Jonathan: Num. 21:6, Deut. 28:15, Deut. 34:5; Targum to Song of Songs: 2:14, 4:1), three in the Yerushalmi Talmud (J. Peah 4a:1, J. Shevi'it 25b; 1, J. Ketubot 65b:1).

293 There are relatively few in the earlier rabbinic sources; Mishnah has four examples and the Tosefta has five, all of which are repeated in the Talmudim. However, other literature like Midrashim, contain a copious amount of stories depicting a bat kol.

294 John Abbott noted that due to the bat kol's appearance in the Mishnah [Yev. 16:6] permitting a woman to remarry on the basis that a disembodied voice declared "so-and-so" to be dead, "almost force us to believe that in some parts of Jewish Palestine there must have been a gross superstition about oracular voices from an unseen source, and that these were actually allowed to have the force of Law in special instances.” John Abbott, From Letter to Spirit; an Attempt to Reach through Varying Voices the Abiding Word, (London: A. and C. Black, 1903), 154.

${ }^{295}$ It was not edited in Jerusalem as one may be lead to think but in the cities of Tiberias, Zippori, and Caesarea, including some Babylonian Amoraim. Steinsaltz, Talmudic Images, 164.
} 
self-government, and consequently, scholarship in the land. ${ }^{296}$ This is why the Jerusalem Talmud was never really formally edited as evidenced by its weak transitions between and within sections and parallel discussions appearing in separate places without cross references to each other and sometimes duplicating and contradicting each other. ${ }^{297}$ It never reached the popularity of the massive and punctiliously edited Babylonian Talmud.

The Palestinian Talmud also contains very little Haggadic material, though it was a favorite topic among the Palestinian rabbis, particularly for its capacity to induce hope in the midst of arduous religious and political challenges; it was collated by later generation of scholars in what are known as Midrashei Haggadah (aggadic exegeses). ${ }^{298}$ The Mishnah, the first major rabbinic work was compiled by R. Judah Ha-Nasi around 200 CE. ${ }^{299}$ It was upon the organizational structure of the Mishnah that the editors of the Bavli formulated their work. ${ }^{300}$ After the patriarch's death, no one was believed to be qualified enough to succeed him which in turn contributed to the destabilization of the movement in Jewish Palestine. In addition, deteriorating political and economic

\footnotetext{
${ }^{296}$ Adin Steinsaltz, The Essential Talmud (New York: Basic Books, 2006), 11-12.

${ }^{297}$ Barry W. Holtz, ed., Back to the Sources: Reading the Classic Jewish Texts (New York: Summit Books, 1984). 136.

298 Steinsaltz, The Essential, 77.

${ }^{299}$ Steinsaltz describes it as the, "first and most fundamental collection of halakha of the Oral Torah;" cf. Steinsaltz, Talmudic Images, 160.

300 The Palestinian Talmud only contains thirty-nine of the sixty-three tractates of the Mishnah. Schiffman, From Text, 227.
} 
circumstances in the land increased its weakened state. ${ }^{301}$ This socio-economic and religious decline in the land spurred the growth of the rabbinical movement in Babylon.

As Adin Steinsaltz eloquently expressed, "If the Bible is the cornerstone of Judaism, then the Talmud is the central pillar, soaring up from the foundations and supporting the entire spiritual and intellectual edifice.”302 Its importance for Judaism cannot be overstated. The Babylonian rabbis lived during the rise to power of the Sassanian Empire, ${ }^{303}$ and are credited with having compiled and edited the Babylonian Talmud. The Talmudic corpus can be broken down into four important components as noted by Richard Kalmin: Halachic (legal instruction) statements, Haggadot (lore), interpretations of earlier sources, and objections and questions about opinions expressed by other rabbis. ${ }^{304}$ The focus of this study centers mostly upon the Haggadic portions which contain accounts of the supernatural transmissions from heaven.

My approach to these stories is a descriptive one, paying attention to literary features like themes, language, structure, and parallels. ${ }^{305}$ Moreover, any possible signs of redaction, such as editing that adds or takes away details to the material, though widely maintained by scholars in various degrees and ways, ultimately remains hypothetical, as

\footnotetext{
${ }^{301}$ Steinsaltz, The Essential, 65.

${ }^{302}$ Steinsaltz, The Essential, 3.

${ }^{303}$ In 226 CE the Parthian kingdom was conquered by the Sassanids. Steinsaltz, The Essential, 12.

${ }^{304}$ Kalmin, Sages, xiii.

${ }^{305}$ In this regard I liken the nature of this study to the manner Catherine Hezser described the approach of Arnold Goldberg in his work, Rabbinische Texte als Gegenstand der Auslegung, as "phenomenologicaldescriptive.” Cf. Reimund Beiringer,ed., et al., The New Testament and Rabbinic Literature (Leiden: Brill, 2010), 97.
} 
means of verification are practically non-existent. Catherine Hezser has noted how impossible it is to retrieve the "original” story since these and or traditions circulated for hundreds of years orally prior to being redacted and edited, in addition to having been adapted in numerous contexts and for various reasons; for all these reasons it very difficult to identify original material, rather than later reworked data, with any degree of certainty. $^{306}$

\section{B. Haggadah:}

As stated previously, Haggadah was a major component of rabbinical thought, particularly during Talmudic times. Its origins are ascribed to the Jewish community in

the land of Israel, and grew and developed for more than a millennium. ${ }^{307}$ Furthermore it was birthed in the midst of shifting political and social realities in antiquity such as the destruction of the Temple in $70 \mathrm{CE}$ and the increase of taxes. The rabbis sought a new method to interpret Scripture which would permit them to address the pressing needs of their day. ${ }^{308}$ Though it is unclear how this term came to be identified with certain literary works, its name appears to derive from the Hebrew verb le-haggid which means "to tell" or "to say" which rightly points to its oral texture. ${ }^{309}$ Indeed, it was originally employed at the synagogues each Sabbath during the sermon to the people. For this reason, the

\footnotetext{
${ }^{306}$ Beiringer, ed., et al., The New Testament, 100.

307 Joseph Heinemann writes from about after the conquest of Alexander the Great to at least until the Arab conquest of Jewish Palestine. Geoffrey H. Hartman and Sanford Budick, eds., Midrash and Literature (New Haven, CT: Yale University Press, 1986), 42.

${ }^{308}$ Hartman and Budick, Midrash, 43.

${ }^{309}$ See Joseph Heinemann's article “The Nature of the Aggadah” in Geoffrey H. Hartman and Sanford Budick, eds., Midrash and Literature (New Haven, CT: Yale University Press, 1986), 41.
} 
rabbis sought to make Haggadot memorable and attractive stories for their audiences. ${ }^{310}$ Joseph Heinemann notes that this granted Haggadah an oral flexibility as stories were adapted amongst the sages for the sake of cultural relevance, which in turn points to the primary goal of Haggadah in general.

Haggadot were utilized in order to promote a lesson or teaching of sorts. Joseph Heinemann proposed three general kinds of Haggadot: Biblical, "non-Biblical” or "the tales of the sages,” and “ethical-didactic.”311 However, as Heinemann explains these categories have a degree of overlap with one another, for Biblical Haggadot may also contain historical characters and all Haggadot surely have an ethical point to them. Take for example Abraham's binding of Isaac in Genesis 22. The rabbinic interpretation of this passage shifted the focus from Abraham's submissiveness to God to Isaac's willingness to be sacrificed, in martyr-like manner. This shift can be seen in the retelling of the Akedah in the Palestinian Targum (Targum Neofiti), Josephus, Pseudo-Philo, and later rabbinic works. ${ }^{312}$ This in turn served as the paradigm to which Jews resorted when facing death by enemy forces. It does not seem coincidental therefore that a "voice from heaven” accompanies several rabbinical stories of martyrdom, similarly to the celestial voice which went forth at Isaac's binding.

The bat kol constitutes one motif of the Haggadot for both its Biblical and nonBiblical stories. Yet even stories retrojected into the Biblical period always included

\footnotetext{
310 Hartman and Budick, Midrash, 47.

${ }^{311}$ Hartman and Budick, Midrash, 43.

${ }^{312}$ Flesher and Chilton, The Targums, 461.
} 
some kind of relevant teaching. For example, concerning the destruction of the First and Second Temples, Heinemann notes, "Moreover, there are many Haggadot which in discussing events historically connected with the destruction of the First Temple, such as the legend about Zechariah's blood (see B. Sanhedrin 96b and parallels), are in fact implicitly commenting on the destruction of the Second Temple.”313 Not surprisingly, we find this to be true of the stories depicting a "voice from heaven." The rabbis conceived of the Scriptures as containing multiple meanings which were culled and expounded upon. These in turn were taught, perhaps first, to other sages and then eventually to the common people, such as in the sermons delivered on the Sabbath, as highly relevant principles to live by in their world.

\section{The World to Come}

One major theme associated with the bat kol is entrance into the "world to come." There are twelve passages in the Bavli which address this theme. These passages usually enunciate the phrase: “____ is destined ${ }^{314}$ to life in the world to come!” This phrase is applied to martyrs, rabbis, gentiles, and even collective Israel. ${ }^{315}$ I will provide a brief reading of several examples from this category.

The phrase, “world to come” (olam ha-ba) occurs ten times in the Mishnah, five times in the Tosefta, and eighty-two places in Talmudic writings. Given the large

\footnotetext{
${ }^{313}$ Hartman and Budick, Midrash, 45.

314 מזוּטן (mezumman): "being made ready."

315 Society, Transactions, 188.
} 
number of occurrences, one may infer that this question was important, for the rabbis, and by extension the common people, who were after all were taught by the sages. As teachers of the written and oral Torah, the rabbis would have propagated their teachings of Halacha and Haggadah in order to instruct the fellow rabbis. We discover a concise statement of who is excluded in the world to come: the one who denies the heavenly origins of the Torah and the resurrection, and the one who pronounces the Name in its full spelling. ${ }^{316}$

Another statement germane to the subject of "the world to come" is found in Genesis Rabbah. Here the sages illustrate how the Hebrew language maybe tweaked in order to derive multiple meanings. ${ }^{317}$ For example, R. Joshua ben Levi interpreted Psalm 111:5, "He has given sustenance [teref] to those who fear Him; He will ever be mindful of His Covenant" as "He has given exile [teruf] to those who fear Him in this world; but in the world to come, 'He will be mindful of His covenant.'” One of the important details we glean from this passage is how this sage changes only a Hebrew letter to elicit an alternative reading apropos to his time. Two observations can be made: 1) the text is interpreted in light of real circumstances and 2) the text is also applied to mollify concerns about the current status quo. One may ask, what gave rise to the propagation of heavenly corroborations of entrance into the "world to come?” It is quite conceivable that this topic would have been of keen interest to most individuals simply for its eternal value. As can be seen in the table above, stories of a bat kol and the "world to come" are

\footnotetext{
${ }^{316}$ See B. Avodah Zarah 18a.

${ }^{317}$ Genesis Rabbah 40 2; quoted in Hartman and Budick, Midrash, 46.
} 
not limited just to the eight occurrences of death or martyrdom but also include other stories, such as a bat kol assuring that all of Israel is destined for life in the "world to come,” et al. ${ }^{318}$

Moreover, in Ketubot 103b, we read that a bat kol announced that anyone who was present at Rabbi's (i.e., R. Judah ha-Nasi) funeral is destined for the world to come. Rabbi's laundryman, who was absent on the day he died, discovers the promise and is so grief-stricken that he goes up the roof and jumps to his death whereupon the bat kol appears a second time, stating that the laundryman is destined to enjoy life in the "world to come.” In another story, David defends the right for his son, Solomon, to enter the world to come before a heavenly tribunal of rabbis. ${ }^{319}$ The bat kol intervenes on David's behalf and the tribunal desists from opposing David's plea. Of the twelve passages in the "world to come" category, only four designate a rabbi’s entry into the "world to come" the remaining eight examples announce the same decree for Israel and various individuals. It is for such reasons that one may speculate that it was an important topic for the rabbis. The overarching message in such passages seems to explain that God welcomes repentant sinners and the contrite of heart into "the world to come." With this presupposition, these stories could be read as a form of remedying some of these uncertainties.

Curiously, the importance of eternal life was significant in the works of some Second Temple movements. Scholars have observed that the concept was in some

\footnotetext{
${ }^{318}$ See B. Moed Katan 9a.

${ }^{319}$ See B. Sanhedrin 104b.
} 
instances tied to the idea of martyrdom. The concept of a martyr being "saved" is well grounded in the Maccabean literature and predates the Christian appropriation of such a concept. ${ }^{320}$ Christian writings, such as $1^{\text {st }}$ John 5:13, assure Christians that they have eternal life through Jesus.

Due to Roman rule, the rabbis may have interpreted their own persecutions and to an extent deaths, as a stepping-stone into eternity in addition to the collective memory of the Jewish people. In addition, it is probable that for polemical reasons, such as with Christians, the rabbis reinforced the notion that they were able to merit entry into the "world to come" unlike the heretics of their day. Indeed, heretics and apostates were known to not have a share in the "world to come." ${ }^{321}$ Moreover, rabbinic writings are explicit on avoiding social contact with heretics at all costs, as such individuals were viewed highly dangerous to rabbinic Judaism. Richard Kalmin summarizes the Palestinian rabbinic view as follows:

The urgency and persistence with which Palestinian sources forbid contact between Palestinian rabbis on the one hand and Minim and Christians on the other suggests strongly that such contact took place and was probably routine. Several Palestinian sources urge rabbis and their families to avoid Minim and Christians, contact with whom is depicted as dangerous but sought after because of their skill as healers and the attractiveness of their words. ${ }^{322}$

\footnotetext{
${ }^{320}$ According to Tessa Rajak, "Both the phenomenon and ideology of martyrdom were crystallized in Greek texts written, by Jews, before becoming part of Christianity.” Cf. Tessa Rajak, the Jewish Dialogue with Greece and Rome (Leiden: Brill, 2002) 101. Reference quoted by Daniel Boyarin Dying for God: Martyrdom and the Making of Christianity and Judaism (Stanford: Stanford University Press, 1999), 187, n.9.

${ }^{321}$ See T. Sanhedrin 13:5, which lists heretics (minim), apostates (meshummadin), and the "irreverent" or "skeptic" (apiqoros) have no share in "the world to come."

${ }^{322}$ Kalmin, The Sage, 68.
} 
Therefore, heretical groups like the Christians, in some respects, embodied a kind of theological temptation due to its efficacy to carry out healings and engage in theological arguments from the Hebrew Bible. Rabbinic writings even record several run-ins with heretics (minim $)^{323}$ and non-rabbinic Jews, which suggests that this was a probable reality during the rabbinical movement's time in the land of Israel, especially in the Galilee region. ${ }^{324}$ Nevertheless, the point to be made is that the rabbinic community recorded stories of the bat kol heralding entries into the "world to come," principally in moments of death and or martyrdom. As Kristin Lindbeck, aptly wrote in Elijah and the Rabbis:

The bat kol's 'so-and-so is called to life in the world to come' contains an enormous wealth of meaning in few words, including the whole idea of God's control of every person's destiny at the moment of death. In addition, because it is a formula and not the work of any one author, it indicates that the bat kol was connected in the popular mind with the moment of death, as Elijah was not. ${ }^{325}$ The same holds true for the other characteristic functions of the bat kol, but not as strongly insofar as they are not expressed in such standardized language. ${ }^{326}$

\footnotetext{
${ }^{323}$ The title included Gnostics, Christians, and others; cf. B. Avodah Zarah 16b where R. Eliezer ben Hyrcanus is charged with minut ("heresy"). R. Travers Herford noted that R. Eliezer and minut appear no less than five times in Talmud and Midrash; cf. R. Travers Herford, Christianity in Talmud and Midrash (Clifton, N.J.: Reference Book Publishers, 1986), 185.

${ }^{324}$ A famous case is R. Eliezer's charge of heresy (i.e. Christianity); cf. T. Chullin 2:24; B. Avodah Zarah 16b-17a; Kohelet Rabbah 1:8. For instances where receiving healing from a heretic is prohibited see: T. Chullin 2:20-23; B. A.Z. 27b. See also J. Shabbat 14:4 where R. Joshua ben Levi asserts that it would have been better if his grandson would have died rather than be healed by someone in the name of Yeshu Pandira (i.e., Jesus).

${ }^{325}$ She compares the standard phrase employed by the bat kol with the similar yet different phrase also found in rabbinic writings: "Who is the son of the world to come?" Lindbeck writes that the answer is someone who does a praiseworthy action. Therefore, the bat kol assumes heavenly authority to confirm admittance into the world to come, while other important characters like Elijah do not assume such a task. Cf. Kristen H. Lindbeck, Elijah and the Rabbis: Story and Theology (New York: Columbia University Press, 2010), 55-56.

${ }^{326}$ Lindbeck, Elijah, 56-57.
} 
As Lindbeck has signaled, no other function occurs with the same standardized language, which in my opinion bears significance for categorical purposes. Since the rabbis preserved a standard enough phrase when retelling stories of the bat kol this may signal an original or paramount function for this "heavenly voice.” Lindbeck also comments how these stories exemplify that it was God's prerogative in deciding a person's fate via the bat kol. Certainly, these stories demonstrate God’s exclusive authority as judge, and yet his ruling is depicted as predicated on the actions committed by the individual. Moreover, in at least two of these stories a non-Jew barters with a rabbi in order to achieve life in the world to come. This underscores the authority delegated to the sages by heaven, even to a surprising extent. Lastly, since the person being referred to in these cases has typically died, these words of confirmation are, then, for the sake of the listeners, and later, the rabbis reading these texts. Such a figure was R. Akiva, a second-generation Tanna whose famous martyrdom is one of the most epic stories in all of the Talmud.

Shortly after the destruction in Jerusalem in 70 CE, the center of the rabbinical movement relocated to Yavneh (or Yamnia), ca. 90 CE. ${ }^{327}$ During the next forty years, R. Akiva grew in prominence and authority among his peers. One story that recounts his final moments is found in the Bavli in tractate Berachot ${ }^{328} 61 \mathrm{~b}$. The Yerushalmi contains

\footnotetext{
${ }^{327}$ S.D. Cohen wrote that two groups were unable to be incorporated into the rabbinic fold at Yavneh. Those who insisted on a sectarian self-identification and those who refused to heed the will of the majority. See S.D. Cohen, “The Significance of Yavneh: Pharisees, Rabbis, and the End of Jewish Sectarianism” Hebrew Union College Annual 55. Not surprisingly, we learn of how R. Eliezer did not succumb to the view of the majority in the incident of the oven of "Aknai;" as a result he was treated practically like a heretic by his peers. It is conceivable that sectarian self-identification and dismissing majority rules were, for the sages, two sides of a very dangerous coin.

328 Translated "benedictions” or "blessings.” This tractate pertains to the rules of reciting the Sh'ma and other t'fillah (“prayers”). Maurice Simon noted that this tractate has more Haggadah in proportion to its
} 
a parallel version but excludes the presence of the bat kol, including some slight variations in the details, such as the presence of a Roman governor, and R. Akiva's reading of the Sh'ma rather than preparing to do so as narrated in the Bavli. ${ }^{329}$ It is unclear as to why one version includes the bat kol and the other does not. There are different theories that have been proposed by scholars of rabbinics in terms of the two major sources (the Palestinian and Babylonian Talmudim) such as the plurality of ancient sources or parallel versions as being later revised based on popular needs. ${ }^{330}$

Interestingly enough, Isaiah Gafni has documented about twenty-five parallels between Josephus (Jewish Antiquities) and the Bavli, while none with the Jerusalem version. ${ }^{331}$ Though this finding is not definitive, it nonetheless points to some of the complexities in

\footnotetext{
length than any other tractate. Maurice Simon, trans., Berakhot: Translated into English with Notes, Glossary and Indices (London: Soncino Press, 1948), "Introduction.”

${ }^{329}$ See J. Ber. 14b. There is also a late-third century Midrash on Exodus, Mekhilta that depicts R. Akiva praising God and explaining why His people are willing to die for him. Quoted in Daniel Boyarin, Dying for God: Martyrdom and the Making of Christianity and Judaism (Stanford: Stanford University Press, 1999), 109. For a reading of R. Akiva's martyrdom as a play on martyrdom between rabbinic Jews and (Jewish?) Christians see Boyarin, Dying for God, 103-105. For a different reading than Boyarin's see Paul Mandel's article "Was Rabbi Aqiva a Martyr? Palestinian and Babylonian influences in the Development of a Legend.” Mandel suggests that the Bavli version was dependent upon the Yerushalmi version by changing the focus of the story between R. Akiva and his students rather than with the Roman governor, Turnus Rufus, who oversaw and enforced Hadrian's persecution of the Jews during the Bar Kochba revolt. Mandel suggests that this shift towards the intent as well as the teacher-student relationship is well attested by other examples in the Bavli. Cf. Ronit Nikolsky and Țal Ilan, eds., Rabbinic Traditions between Palestine and Babylonia (Boston: Brill, 2014), 306ff. especially 329.

${ }^{330}$ See Isaiah Gafni’s article “The Modern Study of Rabbinics and Historical Questions” where he briefly discusses these approaches in Bieringer, ed. et al., The New Testament, 43-61.
}

${ }^{331}$ See Bieringer, ed., et al., The New Testament, 57. While the bat kol does not appear in Josephus, he does record the heavenly voices that went forth in the Temple while John Hyrcanus and Simon the Righteous were serving therein; cf. 76-79. 
ascribing firm historical dates for the rabbinical corpus. The Bavli in either case, seems to favor retaining this supernatural element, at least in this story. ${ }^{332}$

The section begins by the writers of the Bavli juxtaposing statements of R. Eliezer b. Hyrcanus, ${ }^{333}$ and his disciple R. Akiva, on the question of loving God with all of one's "soul” (nafshekha) and all of one’s "might” (meodekha). ${ }^{334}$ R. Akiva’s interpretation is, "With all thy soul: [means] even if He takes away thy soul."335 Interestingly enough, the writers proceed to illustrate precisely how R. Akiva's words played out. The text then makes a shift via the phrase, "our rabbis taught” (tanoo rabanan) which may be read as indicative of its Palestinian genesis since the term denotes the rabbinic teachers from Jewish Palestine. It should be noted, that a significant amount of stories depicting the bat kol include this preliminary phrase. ${ }^{336}$

\footnotetext{
${ }^{332}$ Alon Goshen Gottstein suggested, based on evidence from his book The Sinner and the Amnesiac: The Rabbinic Invention of Elisha Ben Abuya and Eleazar Ben Arach that the Yerushalmi version actually came after the Bavli. Hence he remarks the following on the bat kol: "In the Bavli the bat kol is respected, and ultimately avoided; in the Yerushalmi, the significance of the bat kol is diminished to the point of being ignored;” (Stanford: Stanford University Press, 2000), 202.

${ }^{333}$ Sage, tanna ("teacher"), from the land of Israel who lived in the late first century and early second century CE.

${ }^{334}$ Here, "might" (meodekha) is interpreted to mean money.

${ }^{335}$ Isidore Epstein, Hebrew-English edition of the Babylonian Talmud (London: Soncino, 1960), Berakhot $61 b$.

336 Or teniya תניא, which refers to a Baraita. Cf. Marcus Jastrow, Dictionary of Targumim, Talmud and Midrashic Literature (London: Trübner, 1886), 1,681.
} 
The story recounts how a "wicked government”337 prohibited Israel from occupying itself with Torah. ${ }^{338}$ However, a certain Pappos ben Yehudah ${ }^{339}$ finds R. Akiva breaking this prohibition by attracting crowds through the teaching of Torah. Asked if he does not care, R. Akiva relates to Pappos a fanciful parable of a fox speaking to a group of fish fleeing from the nets of fishermen. Essentially, the fish rebuke the fox’s proposal to join him on the land to avoid being captured, disclosing how much more dangerous it would be for them in the foreign-element of the earth. R. Akiva says, "so it is with us, studying Torah is our life and if we neglect it, it would be but true death.” Eventually, R. Akiva is captured by the Roman authorities and is taken to be executed:

When R. Akiba was taken out for execution, it was the hour for the recital of the Shema', and while they combed his flesh with iron combs, he was accepting upon himself the kingship of heaven. ${ }^{340}$ His disciples said to him: Our teacher, even to this point? He said to them: All my days I have been troubled by this verse, 'with all thy soul', [which I interpret,] 'even if He takes thy soul'. I said: When shall I have the opportunity of fulfilling this? Now that I have the opportunity shall I not fulfil it? He prolonged the word ehad $^{341}$ until he expired while saying it. A bath kol went forth and proclaimed: Happy art thou, Akiba that thy soul has departed with the word ehad! The ministering angels said before the Holy One, blessed be He: Such Torah, and such a reward? [He should have been] from them that die by Thy hand, O Lord. ${ }^{342}$ He replied to them: Their portion is in

\footnotetext{
${ }^{337}$ I.e., Rome.

338 These events could be referring to the events leading up to the Bar Kochba rebellion ca. 132-135 CE. Daniel Boyarin comments that Saul Lieberman showed that the Romans did not outlaw Jewish religion but only certain practices that were considered to be conducive to rebellion, including pronouncing God's name in public and public Torah teaching. Cf. Daniel Boyarin, Dying for God: Martyrdom and the Making of Christianity and Judaism (Stanford: Stanford University Press, 1999), 169, n.57.

${ }^{339}$ Daniel Boyarin theorizes that this figure could be construed as a Christian; cf. Boyarin, Dying, 109.

${ }^{340}$ That is reciting the Sh'ma.

341 “One.”

${ }^{342}$ Psalm 17:14.
} 
life. ${ }^{343}$ A bath kol went forth and proclaimed, Happy art thou, R. Akiba, that thou art destined for the life of the world to come. ${ }^{344}$

R. Akiva is sometimes referred to as the proto-typical martyr of Judaism. ${ }^{345}$ R. Akiva's zeal for Torah is not diminished even in suffering and impending death, and he upholds the Halacha of reciting the Sh'ma at its appointed time, in spite of being flayed alive in the process. In dramatic fashion, he is fulfilling the most important commandment both in word and deed, namely, pouring out his life in devotion to God, and consequently loving God with all of his “soul.” The Hebrew verb (yatzah) is utilized to describe the departure of R. Akiva's soul, and in the following line, is also used to describe the appearance of the bat kol. It is as if R. Akiva's ascent into eternity left room for the transmission of a heavenly dispatch.

Also, noteworthy is the bat kol's commendation of R. Akiva's final utterance of the word "echad," though no explanatory remarks are provided. ${ }^{346}$ Literally the text could be translated, "which your soul went out in one.” Beyond the value of uttering this key word in what is the most important prayer of all, this may also be hinting to something greater, namely, R. Akiva’s sole and unwavering devotion to God. Interestingly enough, there are other Talmudic stories that record the last words of a

\footnotetext{
343 Psalm 17:14.

344 Translation from Epstein, Hebrew, Berakhot 61b.

345 Polycarp, church bishop of Smyrna, is also believed to have been martyred during the second century of the Common Era, during which a voice from heaven also spoke, encouraging him to be of good cheer in his final moments. Cf. See Kitto, Cyclopedia, 305.

${ }^{346}$ The Tisha B'av version of the early-medieval work, Arzey halevanon, records the bat kol as declaring, “Fortunate are you, R. Akiva, your body has been purified with every type of purity!” This may be understood to mean that both his body and soul were purified in his last moments.
} 
dying person prior to the commentary of a bat kol. ${ }^{347}$ Indeed, we find this practice carried out in the Biblical text as well. ${ }^{348}$ Both for its theological significance and importance in prayer, R. Akiva’s final word evoked praise from all, including, heaven itself. The bat kol's praise of R. Akiva may be taken to be instructional in multiple facets.

After a brief exchange between the ministering angels and God, God expresses that the lot of the righteous is actually in the world to come. The bat kol then makes a second and surprising final appearance to close the story. R. Akiva is said to be fortunate for he is ready for the life of the world to come. This appears to be the statement which wraps up the entire story. After R. Akiva’s striving to teach and practice Torah and enduring hardship for such, his efforts have ultimately landed him in the world to come; and thus he is fortunate. This in short is the moral of the story: one is made ready for the life in the "world to come” by giving up one’s life for God.

Both statements by the bat kol purport to be hidden information, revelatory remarks from heaven. R. Akiva's last words are viewed in this story as revealing the very depths of his person and what he enunciates is holy and praiseworthy. The first statement appears to confirm R. Akiva's Halachic opinion that with "all of one's soul”

\footnotetext{
${ }^{347}$ Scholars have noted Talmudic stories which ascribe prophetic-like value to a person's final words. The last words of R. Eliezer ben Hyrcanus is one prime example, in which he foretold the death of R. Akiva; cf. B. Sanhedrin 68a. See also B. Bava Metzia 86a, where it recounts the death of Rabbah bar Nachmani who upon dying declared the words "clean, clean" ("tahor, tahor"), where upon a bat kol rang forth declaring him blessed because of his final words insinuating that he died clean. The same is applied to R. Eliezer, whose last word was "clean" (tahor) upon dying. This was interpreted by R. Joshua as marking the lifting of the ban proscribed by his peers; B. Sanhedrin 68a.

348 Jacob’s last blessing of his sons in Genesis 48 is espoused in prophetic-like fashion.
} 
could imply even when one loses his soul, so to speak. The second declaration ratifies or rather clarifies the statement previously spoken by God, namely that "their portion is in [eternal] life.” The bat kol explains the expected lot for the righteous is life in the world to come. In short, R. Akiva serves as a model for what exemplary faithfulness and its final recompense look like.

A similar story is recounted in tractate Taanith 29a. ${ }^{349}$ Here again we are introduced to the story with the phrase "tanna," ${ }^{350}$ pointing the reader's attention to a likely Palestinian provenance: "When the wicked Turnus Rufus destroyed the Sanctuary, a decree was placed upon Rabban Gamaliel for execution.” This Turnus Rufus, is the same figure the Yerushalmi version depicts torturing and killing R. Akiva, though he goes unmentioned in the Bavli. However, things apparently played out differently for R. Gamaliel. A certain Roman officer sought out R. Gamaliel ${ }^{351}$ and eventually finds him in hiding.

He makes a proposition to the sage: a life for a life. If Rabbi Gamaliel can assure him life in the world to come, he would save his life. ${ }^{352}$ The rabbi agrees. Once the sage

\footnotetext{
${ }^{349}$ Taanith means "fast." B. Avodah Zarah 10b, contains a story of a Roman Ketiah bar Shallum, who sought to avoid the persecution of the Jews, only to be sentenced to death himself for such a suggestion, not before circumcising himself before being killed whereupon the bat kol rang forth declaring his entry into the world to come.

350 "It was taught" which occurs four times in this folio (29a).

${ }^{351}$ He was the head of the Sanhedrin at Yavneh. Adin Steinsaltz notes that despite his success in driving and organizing the rabbinic head into a supreme legislative and judicial authority, he was apparently despised and eventually deposed from his position. Cf. Steinsaltz, The Essential, 52.

${ }^{352}$ See B. Avodah Zarah 18a where similar details and words are employed. R. Chanina ben Teradyon is seized for also occupying himself with Torah (as was the accusation of R. Akiva). He is believed to have suffered martyrdom at the same time as R. Akiva. Ernest Trattner dates his death during the Hadrianic persecutions in the years after 135 CE; cf. Trattner, Understanding, 99. His executioner asks if he would assure him life in the world to come if he would hasten R. Chanina's death. The Rabbi swears that this will
} 
confirms the agreement by swearing to him, the Roman officer goes up to a roof and then falls to his death, whereupon the bat kol rang forth declaring, "This officer is made ready for life in the world to come!” Through his actions, the Roman officer has saved the life of R. Gamaliel. The text then inserts a parenthesis; the Romans had a tradition that if they had made a decree and one of them died, they would annul that decree which is then followed by the announcement of the bat kol declaring that the Roman officer is made ready for life in the world to come. ${ }^{353}$

The text then ends with another story that describes some young priests who jumped to their deaths when the First Temple was being destroyed, not after having first addressed heaven and throwing the keys of the Temple upwards, whereupon something like the form of a hand received them. However, rather than a heavenly voice announcing their share in the world to come, verses from the book of Isaiah are quoted as if Isaiah spoke to them upon witnessing their fall. ${ }^{354}$

Once more we find the proclamation that "so-and-so" was made ready for life in the world to come, and both after someone willingly gave up their life. The "voice" is essentially praising the act of the Roman officer, who negotiated with his own life in order to secure life after death. Daniel Boyarin has noted, “There were both Jewish and

be the case. The rabbi dies and the executioner jumps into the flames, whereupon the bat kol declares that both of them were made ready for the world to come.

${ }^{353}$ According to Eitz Yosef (Tosafos to Ketubos 103b) whenever the gemara or "tradition” (i.e., rabbinical commentators in the Talmud) refer to "being made ready" this refers to avoiding a prepatory period of suffering in Gehinom.

${ }^{354}$ Isaiah 22:1-2: "What ails you now that you have all gone up to the housetops, you who are full of noise, a tumultuous city, a joyous city? Your slain men are not slain with the sword, nor dead in battle.” 
Christian thinkers at the time who believed that martyrdom was 'an atonement for sin committed in this or a previous life." 355 This understanding could very well be undergirding these stories. It seems that such noble actions warranted an immediate response from the heavenly courts, so that others may learn of its merit. The willingness to sacrifice one's life for the sake of heaven was met with the highest acceptance from God himself, and was apparently highly esteemed by the sages themselves.

We may begin to discern some overlapping details. For example, the issue of persecution figures into several narratives. The aftereffects of these bloody years, chiefly during the rebellion of Bar Kochba in 132-135 CE, must have remained vivid in the collective memory of the sages for them to transmit these episodes. Again, scholars have remarked how multilayered these rabbinic stories actually are, including a historical stratum. In a few cases, Romans are included in the world to come, such as in the story of R. Gamaliel. The redactors of the Bavli may have felt the need to incorporate these stories in order to portray some of these rabbis as heroic men, whose deaths were not in vain but even resulted in the eternal benefit of others in some special cases. ${ }^{356}$

Overall, this section has presented a sample of cases of the bat kol appearing at the time of death for various figures, including the prominent R. Akiva. Each story

\footnotetext{
${ }^{355}$ Moreover, Boyarin posits "that the rabbis were anxious to justify God's punishment of apparently righteous men via their arrest by the Roman authorities.” Cf. Daniel Boyarin, Dying for God: Martyrdom and the Making of Christianity and Judaism (Stanford: Stanford University Press, 1999), 52.

${ }^{356}$ The focus in rabbinic writings centers around Jews, however, we do find the notion that gentiles can merit entry into the "world to come." In T. Sanhedrin 13:2, Rabbi Joshua and Rabbi Eliezer debate whether gentiles have a share in the "world to come." R. Joshua argued that righteous gentiles do have a place in the world to come and this became the official view of Judaism.
} 
records the virtuous actions of individuals and characteristics like humility, love, and sorrow and repentance which ultimately result in their losing their physical life but gaining an eternal life so to speak. Only three stories in this category recount a bat kol without someone dying. ${ }^{357}$ As previously noted, the bat kol's announcing of a person or people earning a place in the "world to come" in all of the stories reviewed in this section and listed in table 2, could be reduced to a two-fold function: highlighting God's role as ultimate judge and underscoring the impact that individuals have on their own eternal destiny. It seems these were the chief goals in telling these stories.

\section{Praise Toward Individuals}

Certain individuals were singled out for more than just declarations of their share in the world to come. The bat kol praises various Biblical and rabbinical characters for their virtue and piety such as Moses, Hillel, R. Eliezer, and Samuel the Small. This treatment of some Biblical and non-Biblical characters accords with the observed tendency of employing Midrash in order to praise the worthy deeds of the righteous as far as possible. Correspondingly, the rabbis ascribe to certain malevolent figures additional heinous actions ${ }^{358}$ which consequently, sometimes, becomes the subject for words of

\footnotetext{
357 These references are: B. Eruvin 54b, where R. Preida is offered the choice between four hundred more years of life or entrance into the world to come for him and his generation; he chooses the latter but is awarded both by God. B. M.K. 9a, where Israel failed to observe Yom Kippur in the year that Solomon dedicated the Temple, to which the bat kol assured all of Israel that they are prepared for the world to come. And lastly, B. Sanhedrin 104b, that depicts David interceding for his son, Solomon, before the great assembly. The issue was whether Solomon was deemed worthy to enter the world to come. Finally, the judges accept upon the bat kol reminding them of the limit of their jurisdiction. There is another story, which rather than affirming entry into the world to come, excludes it for an individual, namely Elisha ben Abuyah; cf. B. Chagigah 15a.

358 Z.H. Chajes, The Student’s Guide through the Talmud (New York: Phillip Feldheim, 1960), 164.
} 
rebuke and or judgment. Regularly the merit of these individuals is announced for all to hear, even on a daily basis at times. We also find cases where the bat kol endorses an individual for a certain honor or defends the reputation of a sage so as to dispel any misconceptions over such a person.

Generally speaking, the bat kol is timeless; it is recorded at times as echoing in the Biblical period, during times of Moses and the Patriarchs, and during the time of the sages prior and during the writing of the Babylonian Talmud. I have catalogued thirteen stories that fall within this category, not including four repeated stories, such as the story that depicts a bat kol praising R. Hanina ben Dosa; an itinerant miracle worker known for his asceticism. ${ }^{359}$ Thus, Byron Sherwin noted that R. Hanina ben Dosa is presented in typical Bavli fashion as a wonder-worker who derived his theurgic abilities from the knowledge of Torah. ${ }^{360}$ This depiction may be interpreted as an approach that sought to reconcile the figure of the charismatic healer, who may have been uncomfortably similar to controversial figures such as Jesus of Nazareth, for example, with that of the nascent rabbi/sage, the latter espousing heavenly and earthly authority. That is to say the ability

\footnotetext{
${ }^{359}$ B. Ber. 17b, B. Taanit 24b, B. Chullin 86a. Each account contains the phrase. "The whole world is sustained for the sake of my son Hanina, and Hanina my son has to subsist on a kab of carobs from one week end to the next.” A kav is the equivalent in volume of two dozen eggs and were generally eaten during the Sabbatical year or years in which there were scarce crops. Cf. Jacob Howland, Plato and the Talmud (Cambridge: Cambridge University Press, 2011), 242. The emphasis of the phrase "My son" is reminiscent of the Gospel stories portraying a heavenly voice affirming Jesus in like fashion (cf. Mat. 3:16; Luke 3:21-22; John 1:32). In addition, Hanina b. Dosa was considered to be a holy man and miracle worker, such as the time he prayed for and healed R. Yohanan ben Zakkai’s sick son. Cf. B. Ber. 34b.

${ }^{360}$ Based on the suggestions of scholars like Baruch Bokser, the rabbis could have portrayed R. Hanina b. Dosa in the same manner in which they viewed themselves. Earlier depictions in rabbinic literature convey him as a rural wonder worker and in the Yerushalmi as a rabbi/sage figure, concurrent with how the editors may have viewed themselves. Cf. Byron L. Sherwin, Workers of Wonders: a Model for Effective Religious Leadership from Scripture to Today (Lanham, MD: Rowman \& Littlefield Publishers, 2004), 39.
} 
for the rabbis both to heal and to teach the revelation of Torah as given to Moses and handed down to the sages of Israel.

In tractate Sotah 48b, ${ }^{361}$ we are afforded a glimpse into another function of the bat $\mathrm{kol}$ when it expresses the worthiness of an individual to have the Shechinah dwell upon him. The passage begins by discussing the significance of when the former prophets died (i.e., David, Samuel, and Solomon). Their deaths, allegedly, marked the end of the use of the Urim and Thummim. ${ }^{362}$ Moreover, the text reads that with the destruction of the First Temple the Urim and Thumim ceased. The passage then quotes the oft repeated rabbinic saying: "When Haggai, Zechariah, and Malachi died the Holy Spirit departed from Israel; nevertheless they made use of the bat kol.."363 The passage goes on to narrate how on two separate occasions this sign was given to the sages:

A Bat Kol was granted to them from heaven which announced, 'There is in your midst one man who is deserving that the Shechinah should alight upon him, but his generation is unworthy of it'. They all looked at Hillel the elder; and when he died, they lamented over him, 'Alas, the pious man! Alas, the humble man! Disciple of Ezra!' On another occasion they were sitting in an upper chamber in Jabneh; ${ }^{364}$ a Bath Kol was granted to them from heaven which announced, 'There is in your midst one man who is deserving that the Shechinah should alight upon him, but his generation is unworthy of it'. They all looked at Samuel the Little; ${ }^{365}$ and when he died, they lamented over him, 'Alas, the humble man! Alas, the pious man! Disciple of Hillel!' At the time of his death he also said, 'Simeon and Ishmael [are destined] for the sword and their colleagues for death, and the rest of the people for spoliation, and great distress will come upon the nation.' They

\footnotetext{
${ }^{361}$ Also recorded in Tosefta Sotah 13:5.

362 The Urim and Thummim were lots used by the priests to discern God's will on various matters. Cf. Exodus 28:30; Num. 27:21; I Sam. 28:6.

363 This statement and subsequent story are found in T. (Tosefta) Sotah 13:4, 5.

${ }^{364}$ Also spelled Yavneh or Yamnia.

${ }^{365}$ Disciple of Hillel, who died shortly after the destruction of the Second Temple.
} 
also wished to lament over R. Judah b. Baba, ${ }^{366}$ 'Alas, the pious man! Alas, the humble man!' But the times were disturbed and they could not lament publicly over those who had been slain by the government. ${ }^{367}$

Despite the Temple being in ruins, a supernatural sign similar to the Urim and Thummim, is given to the sages. The first person to be singled out is Hillel the elder ${ }^{368}$. No description of his character or acts is made available. He is identified as someone worthy to receive that God's abiding presence (Shechinah) should dwell upon him. Hillel established a school ("house”) which operated from ca. 30 BCE to 20 CE. He was known for his great kindness and gentleness towards all. ${ }^{369}$ His legal rulings were often pitted against the rulings of Shammai (the rival school at the time) but Hillel's views won out an overwhelming majority of the time, constituting the rulings upon which Jewish Law was based. ${ }^{370}$ He was from Babylon but moved to Jerusalem to study without any financial support; he supported himself by working as a woodcutter.

Samuel was given the epithet "small” due to his great modesty, since at least in one occasion he was willing to take on embarrassment in place of another. ${ }^{371}$ He was a disciple of R. Gamaliel II, who was the leader of the rabbinic court while centralized at Yavneh. Interestingly enough, the Mishnah, the earliest rabbinic work dating ca.200 CE,

\footnotetext{
${ }^{366}$ The Soncino commentary considers this sage to be another victim of the Hadrianic persecutions; cf. Isidore Epstein, Hebrew-English edition of the Babylonian Talmud (London: Soncino, 1960), Sotah 48b, n.15.

${ }^{367}$ Translation from Epstein, Hebrew-English, Sotah 48b.

${ }^{368}$ He lived from about the end of the second century BCE to the first century CE.

${ }^{369}$ Epstein, Hebrew-English, "Hillel.”

${ }^{370}$ Apparently the Talmud records over 300 differences of opinions between these two schools. See Epstein, Hebrew-English, "Hillel."

${ }^{371}$ See B. Sanhedrin 11a where he humiliates himself in order to save another embarrassment.
} 
contains a description of a person considered to be worthy of the indwelling of the Divine Spirit: “Zeal brings man into a state of cleanliness, cleanliness advances man to purity, purity leads a man to self-control, self-control to holiness, holiness to humility, humility to fear of sin, fear of sin to Godliness, Godliness makes man worthy of the Ruach haKodesh [Holy Spirit]...”372 We can then infer, in line with the abovementioned understanding, that Samuel's humility was perhaps one trait among others which he embodied.

This story narrates the public endorsement of two pious sages (Hillel the Elder and Samuel the Small) to have God's abiding presence rest on them, yet because of their generation the miracle of God's presence dwelling over Hillel the Elder and Samuel the Small did not occur. ${ }^{373}$ A version found in the earlier work of the Tosefta actually has the word "Holy Spirit” (Ruach ha-Kodesh) instead of Shechinah. ${ }^{374}$ The term "Holy Spirit," was for the rabbis, synonymous with prophecy, hence the Tosefta ${ }^{375}$ narrative is impressing that these two men were worthy to receive the Spirit just like the Biblical prophets of old. ${ }^{376}$ Therefore, despite the rabbinic claim that Biblical prophecy had

\footnotetext{
${ }^{372}$ M. Sotah 9:15.

${ }^{373}$ An enlightening text is B. Sukkah 28a, where we read that Hillel had eighty disciples and that thirty of them were worthy to have the Divine Presence (Shechinah) rest on them as it did upon Moses "our" teacher. It appears to be this same imagery that is being alluded to in reference to these two men. In other words, perhaps it was the view of the writers to compare Hillel the Elder and Samuel the Small with Moses, the great teacher.

${ }^{374}$ T. (Tosefta) Sotah 13:4, 5.

375 Tosefta refers to a collection of Halacha which was compiled by the last Tannaim (ca. 200-220 CE), R. Hiyya and R. Osha'aya, as additions to the Mishnah. Cf. Adin Steinsaltz, Talmudic Images (Northvale, NJ: Jason Aronson, 1997), 165.

${ }^{376}$ One cannot help notice similarities in terminology between this account and the Gospels' description of the Holy Spirit descending upon Jesus in the likeness of a dove (cf. Mat. 3:16; Luke 3:21-22; John 1:32).
} 
ceased, the rabbis show that there were still degrees of prophetic activity taking place in their midst. Surely with the Temple in ruin, God's abiding presence, was believed by the rabbis to no longer be found in such quarters nor among men (prophets). ${ }^{377}$

\section{Stories of Rebuke/Judgement}

\section{A. Retrojected on to Biblical Figures:}

As previously mentioned, through Haggadah the rabbis sought to depict important Biblical characters as blameless, even offering dubious or spurious reasonings for their immoral acts. The same approach was adopted in describing evil characters. Stories are retold which portray wicked people as committing further heinous actions. Z.H. Chajes remarked that this hermeneutic creativity stemmed from the Mishnaic principle $^{378}$ that, “precept draws precept in its train, and transgression draws transgression.”379 In other words, righteous behavior leads to further righteous deportment and wicked behavior leads to further wickedness. Consequently, the rabbis sought to illustrate such a principle in their own Haggadot.

\footnotetext{
Both make mention of a voice from heaven and both make reference to the divine presence resting over individuals. This may this detail may represent a shared understanding of God's Sprit in the Second Temple period. Furthermore, there may be a connection with the reference in Genesis 1:2 with the Spirit of God "hovering" (merachefet), denoting intensity in the Hebrew. Thus, this image is perhaps akin to a hovering hummingbird.

377 See Exodus 34:29-35.

${ }^{378}$ M. Avot 4:2.

${ }^{379}$ Chajes, The Student's, 166.
} 
In the previous chapter, I discussed the rabbi’s ill-favored portrayal of king Nebuchadnezzar. ${ }^{380}$ The political leader responsible for razing the Temple and exiling the people in 586 BCE is depicted as being sentenced to punishment in the afterlife. The rabbis elaborate a story, building on that found in the book of Daniel, that additional words were delivered to Nebuchadnezzar informing him that rather than being raised high in power and glory, he will be cast down to the depths of the pit. The words of the bat kol are, "wicked man, son of a wicked man... who led the whole world in rebellion against Me during his reign...but to the nether world will you be brought down, to the depths of the pit!” Here we see the rabbis apply the principle that certain actions beget more of the same action. Hence the emphatic phrase, "wicked man, son of a wicked man” is underscoring a continuation of wickedness inherited by Nebuchadnezzar's progenitor. ${ }^{381}$

A second text, B. Shabbat 149b, asserts that Nebuchadnezzar engaged in homosexual activity with his own royal staff. It records that while this wicked man (i.e., Nebuchadnezzar) was alive, not a single creature had joy in its mouth. ${ }^{382}$ Furthermore, upon his descent into Gehenna ${ }^{383}$ the people there became afraid, whereupon the bat kol declared to him, "Go down and be laid with the uncircumcised." 384 The additional details

\footnotetext{
${ }^{380}$ B. Pesachim 94a and B. Chagigah 13a.

${ }^{381}$ See B. Megillah 15a where the same phrase is applied to Ishmael, son of Nethaniah in Jeremiah 41:1 who slew Gedaliah, the Judean official placed by the Babylonians, and many other Jews. See also B. Gittin $56 b$.

${ }^{382}$ Quoting from Isaiah 14:7: “The whole earth is at rest and quiet; they break forth into singing.”

${ }^{383} \mathrm{Hell} /$ place of torment in the afterlife.

${ }^{384}$ Quoting from Ezekiel 32:19.
} 
related in this Haggadah strengthen the rabbis' perception of Nebuchadnezzar as a highly-immoral person receiving his just punishment. ${ }^{385}$

Another ugly figure spoken of by the rabbis is Titus, the Roman general (and later emperor) responsible for carrying out the destruction of the Temple in $70 \mathrm{CE}$. In fact, the same phrase applied to Nebuchadnezzar is spoken to Titus, however, with an extra detail, "wicked man, son of a wicked man, son of Esau the wicked." ${ }^{386}$ Once more, the narrator is connecting a contemporary and evil adversary with an ancient one, namely Esau. ${ }^{387}$ The story recounts that Titus allegedly profaned the Holy of Holies with a prostitute. As Titus sailed away with objects from the Temple, a voice from heaven rang forth issuing a challenge to the general, namely to fight against a little gnat. Titus agreed to the challenge. The gnat infiltrated his brain and caused him discomfort for seven years. Prior to his death, Titus asked for his ashes to be spread over the seven seas so that the God of the Jews should not find him and bring him to trial. Upon opening his skull they discovered that the gnat had grown. ${ }^{388}$ God ultimately vindicates His name, by defeating him who had desecrated God's very dwelling place.

As in the previous section, the reader may notice historical figures and or events that are embedded in these stories. Similar details were added to both the stories of,

\footnotetext{
385 The Soncino commentary interprets a part of this passage to imply pederasty. This ascription may be a covert allusion to the practice amongst the Romans, cf. Epstein, Hebrew-English, B. Sh. 149b, n.24.

${ }^{386}$ See B. Gittin 56b.

${ }^{387}$ Esau, is sometimes a sobriquet for Rome/Christianity.

388 The text states that a Tanna taught that it was, "like a young dove two pounds in weight."
} 
Nebuchadnezzar and Titus, who were associated with destroying the Temple at various points in history. The motif of the destruction of the Temple, serves as an important point of interest for the rabbis which is conveyed in these particular stories of a bat kol pronouncing various judgments. ${ }^{389}$ These stories lend themselves to be viewed as a kind of unscripted ending, in which God's judgment is swiftly carried out and both His own dignity and that of His people are redeemed. The humiliation brought about by these figures is returned upon their own heads in greater and more graphic measure. The bat kol figures as the celestial messenger appearing suddenly in these stories as God's mouthpiece, rebuking them both for their pride and actions. It is the mechanism resorted to for introducing God's intervening actions; it is employed as a voice of justice and hope, concepts surely the rabbis were creatively transmitting in order to promote hope and faith in the God of Israel among other purposes.

\section{Halacha}

Of the sixty-two stories presented in table 2, eight pertain to Halacha. Halacha comes from the Hebrew (halakh) meaning "to walk.” The basic idea is living one’s life in conformity with the Torah. Isidore Epstein defines the rabbinic Halacha chiefly as, "the final decision of the rabbis, whether based on tradition or argument, on disputed rules of conduct.” ${ }^{390}$ However, there is one well-known story which is pertinent to this

\footnotetext{
${ }^{389}$ It should be noted, that the sins of the Jewish people are also attributed to having caused its destruction. In B. Ber. 3a it states that thrice daily a heavenly voice coos like a dove, "Woe to the children on account of whose sins I destroyed my house and burnt my Temple and exiled them among the nations of the world!" The section then proceeds into another story which also includes the notion of the heavenly voice (bat kol).

${ }^{390}$ A secondary definition provided by Epstein is that it refers to those sectionss of rabbinic literature which pertain to legal matters, as opposed to Haggadah. Cf. Epstein, Hebrew-English, "Halachah."
} 
study’s discussion in which a "heavenly voice” apparently is interjected in a protracted legal debate. The two following stories could be placed in the category of praising or endorsing an individual, however, since the reason for heaven’s selecting an individual over another in terms of Halacha, I have placed them in the category of stories pertaining to Jewish Law.

\section{A. Hillel vs. Shammai:}

It is when the two schools of Hillel and Shammai were at a stalemate in terms of which school's legal rulings should be followed. ${ }^{391}$ Shammai had the reputation of being very austere and conservative while Hillel was known to be more progressive and flexible in terms of Halacha. The story is found in the Bavli in tractate Eruvin 13b. The text begins by exhibiting a dialectic approach to Halacha. A sage called Sumchos, was able to give forty-eight justifications for ruling something impure and forty-eight justifications for ruling something pure. ${ }^{392}$ Shortly after we read of the prolonged standstill between these two important schools of learning:

Rabbi Abba said in the name of Shmuel, "For three years, the House of Hillel and the House of Shammai argued. One said, 'The Halacha is like us,' and the other said, 'The Halacha is like us.' A heavenly voice spoke: "These and these are the words of the living God, and the Halacha is like the House of Hillel."' A question was raised: Since the heavenly voice declared: "Both these and those are the words of the Living God," why was the Halacha established to follow the opinion of Hillel? It is because the students of Hillel were kind and gracious. They taught their own ideas as well as the ideas from the

\footnotetext{
391 Jacob Neusner dates them from 1-70 CE. Jacob Neusner, From Politics to Piety: the Emergence of Pharisaic Judaism (Englewood Cliffs, N.J.: Prentice-Hall, 1972), xii.

392 Generally speaking these concepts pertain to life and death, the closer an object comes closer to death the more it is increases in ritual impurity. Ritual purity mostly applied to offering sacrifices and sacred objects. For example, priests and members of their families were obliged to ritually immerse themselves before eating of the sacrifices. However, after the destruction of the Temple, two aspects remained relevant: menstruation/childbirth and priestly laws of purity. Cf. Steinsaltz, The Essential, 231-235.
} 
students of Shammai. Not only for this reason, but they went so far as to teach Shammai's opinions first. ${ }^{393}$

The story purports that sages were at a loss as to whose legal decisions should be followed at a certain point in time. Alexander Guttmann considered this incident to have taken place while the Bet Din Ha-Gadol (“Great Court”) ${ }^{394}$ resided at Yavneh, shortly after the destruction of the Temple. ${ }^{395}$ No details are given as to the context of the debate, such as how it began in the first place or over what issue? In a rather unexpected turn of events, God is said to have intervened bringing lucidity. Heaven acknowledged the worth of each school's teachings, albeit the house of Hillel was deemed superior. ${ }^{396}$ The bat kol's declaration fits the overall context of the passage which centers upon the dialectic nature of Halachic discourse. Naturally, the question follows why Hillel's words and not Shammai's were preferred. The bat kol offered no rationale for the endorsement. Rather the narrators of the text explain the reasoning behind why the Halacha followed Hillel and not Shammai. The students of Hillel were kind and gracious, even exhibiting deference to the opinions of their rival by speaking their words first. However, in a related passage, J. Yevamot 9a, we notice the explicit reference to the bat kol in the implementation of the Halacha:

One should either follow Beth Shammai in both their lenient and their strict rulings; or Beth Hillel in both their lenient and their strict rulings. This, however, refers to the period prior to the bat kol. Yet, after the sounding of the bat kol, the Halacha is always

\footnotetext{
393 Translation from Koren Talmud Bavli Tractate Eiruvin, Daf Yomi B \& W Edition (Koren Pub, 2013).

${ }^{394}$ Also known as the Sanhedrin.

395 Alexander Guttmann, Rabbinic Judaism in the Making: A Chapter in the History of the Halakhah from Ezra to Judah I (Detroit: Wayne State University Press, 1970), 106.

${ }^{396}$ However, according to Alexander Guttmann Halachoth (legal decisions) decided in favor of Shammai prior to the bat kol remained in effect. Cf. Guttmann, Rabbinic Judaism, 119.
} 
in accordance with Beth Hillel, and everyone transgressing the words of Beth Hillel is guilty of death... Where did the bat kol come forth? Rav Bibi said in the name of Rabbi Yohanan: ‘in Yavneh.”397

What is peculiar is the description of the bat kol as a marker. Pre-bat kol, rulings from either school were permitted, post-bat kol, only the words of Hillel became binding. Nevertheless, there were exceptions to the Halacha "always” following Hillel.

According to Guttmann this indicates that the sages relaxed the principle of Bet Hillel's dominance while allowing a few rulings of Bet Shammai to stand. ${ }^{398}$ Moreover, there are cases where the superiority of Bet Hillel is ignored by the sages, which here includes the bat kol. In M. Bava Metzia 3:12, R. Akiva upholds an opinion contrary to both Hillel and Shammai, in so doing disregarding the bat kol. Later Amoraim, Samuel and R. Yohanan endorse R. Akiva’s Halacha, following R. Akiva’s precedent. ${ }^{399}$ Other notable sages like Rabban Gamaliel II ${ }^{400}$ and R. Eliezer b. Hyrcanus, occasionally also supported Shammaitic views.

Thus, the change in Halacha is actually verbalized via the sages and not "the voice” despite its importance in marking a transition. Hence, we read there was no technical legal basis for the decision; it was not because one school possessed more legal acumen than the other; rather, it was on the basis of their character for which they were favored. This story dovetails with the previously reviewed story of the bat kol

\footnotetext{
397 Translation from Guttmann, Rabbinic Judaism, 105.

${ }^{398}$ Guttmann, Rabbinic Judaism, 116.

399 See B. B.M.43b.

${ }^{400}$ See M. Betza 2:6; B. Ber. 43b, 53a; B. Yev. 15a.
} 
identifying Hillel as a worthy recipient of the divine presence. ${ }^{401}$ Further on in the text we read, "[This story is] to teach you that whoever degrades himself, Hashem raises him, and whoever raises himself, Hashem degrades him." ${ }^{402}$ A moral teaching is elucidated, namely that exalting oneself will cause one to be humbled and humbling oneself will cause one to be exalted. Not surprisingly then, the stalemate between the schools of Shammai and Hillel is alluded to in five other stories in the Bavli, in which each narrative displays the divergent views of Hillel and Shammai on any given legal matter. ${ }^{403}$

Such an example is found in B. Berachot 51b, where the writers record a debate over what comes first, the blessing over the day or the blessing over the wine? Shammai is of the opinion that one should pronounce the blessing over the day first, and then the wine, because the day causes the wine to be brought. While the narrator provides the reasoning for each side, the narrator twice states, "The Halacha is according to the word of Hillel.” Besides providing the supporting arguments the narrator further corroborates this fact by recalling that the bat kol sanctioned Hillel's Halacha. Nevertheless, the author cunningly admits that he can say this statement was made prior to the advent of the bat kol, implying that the sages had already decided the matter or he could say that it was made after the voice from heaven ratified Hillel's rulings, thus appearing to lend some Halachic credence to the bat kol.

\footnotetext{
${ }^{401}$ See B. Sotah 48b and B. Sanhedrin 11a.

402 Translation from Koren Talmud Bavli Tractate Eiruvin, Daf Yomi B \& W Edition (Koren Pub, 2013). This statement seems to be derived from Proverbs 29:23, “A man's pride will bring him low, but the humble in spirit will retain honor."

${ }^{403}$ See B. Ber. 51b, Pesachim 114a, Eruvin 6b, Yev. 14a, Chullin 44a.
} 
Interestingly enough there was debate over whether or not to allow a woman to remarry on the basis of a bat kol. In M. Yevamot 16:6 it is said if it is heard that a woman's husband has died yet the person who voiced such information is not found, the testimony remains valid. According to B. Yevamot 122a, Rabbath son of Shmuel said it was taught in a Baraita that they do not permit a woman to remarry on the basis of a heavenly voice. However the house of Hillel says that they do permit a woman to remarry on the testimony of a "heavenly voice."

In conclusion, the bat kol played a precarious role in terms of Halacha. In one famous legal debate it was acknowledged as influential; though to what degree remains ambiguous. The Halacha did generally follow the school of Hillel. The Halachic influence and authority of the bat kol did not translate to later generations, though its presence in one determinant case was alluded to repeatedly. Reasons for this discrepancy include the fact that tension between the two schools must have dissipated after the deaths of their leaders, Shammai and Hillel, in addition to the incident of the "oven of Aknai” where R. Joshua explicitly rejected the weight of a heavenly voice in legal matters.

\section{B. Rabbinic Authority and Morality:}

The Talmud records one special case in which the heavenly voice was outright dismissed only later to be revealed to have been a test from God; it is the story known as the "oven of Aknai." 404 The matter at hand was the ritual purity status of an oven cut into

${ }^{404}$ B. Bava Metzia 59b. 
pieces and joined together by sand. R. Eliezer ben Hyrcanus ruled it was clean (not susceptible to ritual impurity because it was not a single utensil) while the other sages deemed it unclean (susceptible) and as a result to be destroyed upon contracting the status of impure. R. Joshua's dismissal of the bat kol in legal matters is referenced in several places in the Bavli. ${ }^{405}$ Both he and R. Eliezer b. Hyrcanus, both second-generation Tannaim (ca.90-130 CE), are debate partners of sorts, disagreeing over the interpretations of the schools of Shammai and Hillel. This is a famous affair that has elicited extensive commentary and interpretation. ${ }^{406}$ In this story, the heavenly voice responds to R. Eliezer b. Hyrcanus' defense in seeking to persuade his colleagues that an oven cut into several pieces was not susceptible to ritual impurity; the sages refused to adopt his view, the reason is not provided. ${ }^{407}$ Rather, Scriptural justifications were put forth by the sages to prove to God that He was beyond His jurisdiction in intervening in this matter of Halacha, since the rabbis argued that such authority had been given by God to them back at Sinai. ${ }^{408}$

\footnotetext{
${ }^{405}$ B. Eruvin 7a; Pesachim 114a.

${ }^{406}$ For a detailed and comprehensive analysis see Jeffrey Rubenstein, Talmudic Stories: Narrative Art, Composition, and Culture (Baltimore: The John Hopkins University Press, 1999), 34-63.

407 Once again in B. Sanhedrin 104b we read of David defending the reputation of his son, in order for Solomon to be admitted into the world to come. The Great Assembly also dismisses the miraculous sign of fire descending from heaven and the sound of the first bat kol, they desisted after it came forth a second time.

${ }^{408}$ The passages cited to prove that a heavenly messenger should not intervene on the matter are: Deut. 30:12: "It [commandment to obey the Mosaic covenant] is not in heaven, that you should say, 'Who will ascend into heaven for us and bring it to us, that we may hear it and do it?'” This verse is cited so as to assert that Torah is not in heaven. The second passage is Exodus 23:2: "You shall not follow a crowd to do evil; nor shall you testify in a dispute so as to turn aside after many to pervert justice." It is interpreted by R. Joshua to mean to incline after the majority.
} 
Jeffrey Rubenstein draws a logical connection between the Mishnaic teaching that precedes the story in order to comprehend what the story is really about. ${ }^{409}$ That text reads:

Just as there is wronging in business, so there is wronging in words. One should not say to him, 'How much is this object?' when he does not plan to buy it. If he was a penitent, one should not say to him, 'Remember your former deeds!' If he descended from proselytes, one should not say to him, 'Remember the deeds of your forefathers,' as it is written, Do not wrong or oppress the proselyte [Exodus 22:20]. ${ }^{410}$

Rubenstein comments, "These Halachic and literary contexts, especially in relation to the final line of the story, ${ }^{411}$ suggest that the story's meaning must be related to verbal wronging and shaming in general." ${ }^{412}$ Indeed the overarching point of the story may be that verbal wronging and shame are unjustifiable, as evidenced by the comments both at the beginning, in the instruction to avoid wronging others in business, and Imma Shalom's (R. Eliezer's wife) words at the end of the story stating that all gates are closed except for those of wronging.

Rab Judah begins retelling the narrative of the "oven of Aknai”; he is often depicted in the Bavli as articulating stories of the bat kol, in the name of one of his two teachers; Rav or Shmuel. ${ }^{413}$ However, as pointed out by Catherine Hezser this should not

\footnotetext{
${ }^{409}$ B. Bava Metzia 58b.

${ }^{410}$ The Mishnaic teaching comes from M. Bava Metzia 4:10. Cf. Rubenstein, Talmudic Stories, 35.

411 "All the gates are locked except for the gates of [verbal] wrongdoing." Meaning that the prayers of the wronged are always before God. These are the words uttered by R. Eliezer's wife upon seeing her husband fall on his face in a gesture of prayer and humility so that God would avenge the wrong he suffered at the hands of the sages. Shortly before, R. Gamaliel is signaled to have died.

${ }^{412}$ Rubenstein, Talmudic Stories, 36.

${ }^{413}$ At least five other stories; B. Ber. 17b; Sh. 14b; Sh. 149b; Eruvin 21b; M.K. 18b. Rab Judah (Judah ben Ezekiel) was a second-generation Amora (250-290 CE) in Babylon. He was a disciple of first-generation
} 
be misconstrued as historiographical. ${ }^{414}$ That is to say ascribing authorship of the tradition to Rab Judah himself. ${ }^{415}$ The incident is also referred to in earlier sources like the Mishnah, ${ }^{416}$ Tosefta, ${ }^{417}$ and Yerushalmi. ${ }^{418}$ R. Eliezer's unwillingness to acquiesce to the view of the majority was construed as dangerous. This was exacerbated by his reliance on supernatural feats: a carob tree uprooting itself, water flowing backwards, walls leaning over, and ultimately a heavenly voice that enunciated:

Why are you disputing with R. Eliezer? The Halacha is in accordance with him in all circumstances! R. Yehoshua [Joshua] rose to his feet and quoted a portion of a verse [Deut. 30:12] saying: 'The Torah is not in Heaven.' R. Yirmiyah explained: Once God already gave the Torah to the Jews on Mount Sinai, we no longer pay attention to heavenly voices that attempt to intervene in matters of Halacha; for You, God, already wrote in the Torah at Mount Sinai [Exodus 23:2]: 'After the majority to incline.' From this we learn that Halachic disputes must be resolved by majority vote of the rabbis. God could not contradict His own decisions to allow Torah questions to be decided by free debate and majority vote. ${ }^{419}$

Interestingly enough, the passages cited are appropriated to convey a specific meaning that seems foreign to their original contexts. ${ }^{420}$ This demonstrates a kind of

Amoraim (230-250 CE), Rav (Abba Arika) and Shmuel, who studied either directly under Judah Ha-Nasi or under his students.

${ }^{414}$ See Reimund Beiringer,ed., et al., The New Testament and Rabbinic Literature (Leiden: Brill, 2010), 99.

${ }^{415}$ William Scott Green upheld that the main purpose of these attributions was to separate from whom traditions were received from. Cf. Bieringer et al., The New Testament, 99.

${ }^{416}$ M. Kelim 5:10.

${ }^{417}$ T. Eduyot 2:1. Lists four items R. Eliezer deemed pure or clean, and the sages impure, with the "oven of Aknai” being one of those. See Rubenstein, Talmudic, 48.

${ }^{418}$ J. M.K., 81c-d.

${ }^{419}$ Steinsaltz, Talmudic Images, 60-61.

${ }^{420}$ Deut. 30:11-12 reads, "For this commandment which I command you today is not too mysterious for you, nor is it far off. It is not in heaven, that you should say, 'Who will ascend into heaven for us and bring it to us that we may hear it and do it?” The context here refers to obeying the words of the covenant. The second text, Exodus 23:2 reads, "You shall not follow a crowd to do evil; nor shall you testify in a dispute 
hermeneutical liberty employed in order to justify an argument. The miraculous signs were viewed as illegitimate proof in what was strictly a legal debate. Rather than aiding R. Eliezer's cause, they precipitated his exit from the ranks of leadership. ${ }^{421}$

Alexander Guttmann notes, "There is no trace in Rabbinic Literature that the bat kol had been outlawed for legal matters (or for theology) prior to this event [R. Eliezer's excommunication].”422 Guttmann associates R. Eliezer's earlier accusation of heresy (i.e., Christianity) ${ }^{423}$ and the rabbinic perception of Christianity as magic, to imply that the ban could not have been merely over the ritual purity status of an oven that was cut into pieces and joined together by sand. ${ }^{424}$ Such a reading is an intriguing proposition, and has been echoed by scholars like Daniel Boyarin.

The implication is that the narrative is a modified account of what really transpired, revealing certain key details (the excommunication of R. Eliezer) while concealing others (his association with heresy). In other words, the text leaves room for questions, which lends itself for speculative readings in conjunction with other rabbinic material. I hope to have shown how interrelated these stories are. Perhaps the text is

\footnotetext{
so as to turn aside after many to pervert justice.” The passage seems to carry the opposite meaning of how it was quoted.

${ }^{421}$ In addition, his having been accused of minim ("heresy") at one point, raises even greater suspicion as to what exactly prompted his excommunication. For an intriguing read see Daniel Boyarin Dying for God, 156.

${ }^{422}$ Alexander Guttmann, The Significance of Miracles in Talmudic Judaism (Cincinnati: Hebrew Union College Annual, 1947), 386.

${ }^{423}$ The incidents found in T. Chullin 2:24 and B. Avodah Zarah 16b-17a.

${ }^{424}$ If ruled to be susceptible to ritual impurity it would have to be destroyed upon contracting the status of impure. If not, then by purifying the oven through immersion would permit the oven to be reused in the case it is believed to have contracted ritual impurity.
} 
hinting at the real reason for his banishment, namely the appeal to miracles which conflicted with the sages' authority. Be that as it may, it is noteworthy that the bat kol, a phenomenon normally cast in a favorable light by the writers, is diminished in import in this particular account but not without reason. It serves as evidence that the sages did not operate justly towards R. Eliezer in their decision to excommunicate him, who in turn is vindicated by the mayhem that is unraveled. The text states that a third of the world's olives, wheat, and barley were burned up and that anywhere R. Eliezer cast his gaze burned up. Though it was not heeded in the aforementioned example, it also indirectly highlighted the sages' authority to adjudicate legal matters and even to ban individuals for the greater good of the community. Consequently, even though the sages may have had legitimate legal authority in excommunicating a fellow sage, they did not have authority to wrong him in the process which is made evident by the disastrous consequences that follow, including the death of R. Gamaliel.

The bat kol did not have the footing to determine legal outcomes, though at one point in time it was believed to have arbitrated between the two main schools of the first century CE. Yet its decision is reckoned to have supported the majority decision of the rabbis prior to intervening in that rabbinic deadlock. Perhaps the writers conflated a received tradition with a legendary story so as to give the legal ruling (i.e., Halacha follows Hillel) more solidarity, while maintaining that legal decisions cannot be derived from the supernatural, as signs can be produced to lead people astray. Its restricted nature was best exemplified in R. Eliezer's confrontation with the sages. Legal authority rested on the shoulders of the rabbis and no one else is how the story panned out. Yet this is not without its complexities as the sages experienced the hazardous aftermath of 
their brash ruling. Ultimately the story seems to vindicate R. Eliezer in a roundabout way. His prayers are heard and more supernatural signs follow, though he is never released from his ban.

\section{Miscellaneous}

There are sixteen stories that remain to be addressed under the category I have termed "miscellaneous." ${ }^{425}$ The bat kol in these accounts does not appear to be as instructive as the ones previously discussed. They randomly appear and the topic being addressed varies from story to story. In other words, the message the bat kol delivers is not consistent but differs in story and content. Examples include God halting a sage from further divulging his mysteries or the bat kol instructing a rabbi to give back to the angel of death his knife because it is needed for other creatures. Surely, in such examples the legendary nature of these stories is more palpable. However, it was recorded that a bat kol was heard in the holy of holies before and during the time of the Hasmonean dynasty and indeed the Jewish-Roman historian Josephus records a similar account which begs the question why are there two accounts (rabbinic and Josephus) that record the same event? ${ }^{426}$ I have not researched a possible answer to this question, though it is plausible

\footnotetext{
${ }^{425}$ As referred to in the previous chapter there is also a minimal oracular function which is ascribed to the bat kol. In the opinion, of Saul Lieberman, this function became more popular from the third century CE and on, after the period of the Tannaim. No clear examples of this kind are found in the Bavli. The Yerushalmi does contain a clear example of this function, in J. Sh. 6:9; two stories contained therein illustrate the point. The first depicts Bar Kappara going into a town and hearing children reciting a verse from Exodus 21:3, "If he comes in by himself, he shall go out by himself; if he comes in married, then his wife shall go out with him," speaking about a Hebrew slave. The children's recitation is understood to be prophetic. The second portrays R. Yohanan and R. Simeon b. Lakish planning to visit their colleague Samuel, in Babylon. As they passed a class, they heard the children read from a verse that said, "And Samuel died" and they understood this to be an omen.

${ }^{426}$ See Josephus Ant. XIII, 10, 3.
} 
that the story is based off an actual supernatural event or a similar tale around which the story of the bat kol developed. Therefore, in the case of this story, it is not out of the question to presume some historical basis given the multiple attestations to this event.

The accounts address in which language one should recite the twice daily "eighteen benedictions" in order to be heard by the ministering angels. Rab Judah states that one should never pray them in Aramaic, if one wishes to be heard, since this was taught by R. Yohanan. The text then proceeds to give a rejoinder from the Tannaim: Behold it has been taught: Yohanan, ${ }^{427}$ the High Priest, heard a bat kol issue from within the Holy of Holies announcing, 'The young men who went to wage war against Antioch have been victorious. It also happened with Simeon the Righteous ${ }^{428}$ that he heard a Bath $\mathrm{Kol}$ issue from within the Holy of Holies announcing, 'Annulled is the decree which the enemy intended to introduce into the Temple'. Then was Caius Caligula slain and his decrees annulled. They noted down the time [when the Bath Kol spoke] and it tallied. Now it was in Aramaic that it spoke! - If you wish I can say that it is different with a Bath Kol since it occurs for the purpose of being generally understood; or if you wish I can say that it was Gabriel who spoke; for a Master has declared: Gabriel came and taught [Joseph] the seventy languages. ${ }^{429}$

It is unclear if this story was derived from the Josephus account or if both Josephus and the rabbis drew from a common source. Either way, the reason for mentioning the bat $k o l$ is to show that one can pray in Aramaic, if one chooses, at least for general prayers. The proof lies in that the bat kol allegedly communicated in Aramaic to the high priest, Yohanan, and Simon the righteous. Hence it is presumed that one could pray in Aramaic and be understood. The text does not explain why the ministering angles were believed

\footnotetext{
427 John Hyrcanus was a Maccabean ruler (134-104 BCE).

${ }^{428}$ Priest who lived during the fourth and third century BCE, believed to have greeted Alexander the Great. He made repairs to the Temple and helped strengthen the fortifications of the city. He stated that the world rests on three things: Torah, the Temple, and works of charity. Cf. Moore, Judaism, vol. I, 34-35.

${ }^{429}$ Translation from Epstein, Hebrew, B. Sotah 33a.
} 
unable to comprehend prayers in Aramaic, and further that Gabriel is conversant in seventy languages. However, in the beginning of the passage, the Talmud lays out the prescriptions for prayers as found in the Mishnah. ${ }^{430}$ The Mishnaic text stipulates which prayers may be uttered in any language ${ }^{431}$ and which are required to be spoken in the "holy tongue," namely Hebrew. ${ }^{432}$

The bat kol was believed to manifest itself in intelligible communication. Furthermore, it was spoken of in the same category as angels, which is a detail not made explicit before. ${ }^{433}$ The understanding was that if the bat kol communicated through Aramaic, either the angels understood that vernacular or it was none other than the angel Gabriel who was familiar with Aramaic. The military victory against "Antioch" 434 and the annulment of the decree against the Temple do not have clear historical connections. Both are conceivably good news for the Jews at that time, the defeating of a Seleucid king and the preservation of the holy Temple.

\footnotetext{
${ }^{430}$ M. Sotah 7:1-6.

431 The paragraph of the suspected adulteress ("Sotah"), the confession in bringing the second tithe [Deut. 26:13-15], the recital of the Sh'ma, the Tefillah (i.e., "eighteen benedictions”), the grace after meals, the oath of testimony (against withholding evidence), and the oath of the deposit (that it has not been stolen if found missing).

432 Offering of the first fruits, the formula of halitza (ceremony freeing a widow from marrying her brother in-law), the Blessings and the Curses, the priestly benediction (Num. 6:24ff), blessings of the High Priest, the section of the king, the section of the calf whose neck is to be broken, and the words addressed to the people by the priest in battle.

${ }^{433}$ Maimonides, compared this description of the bat kol with that of an angel. Maimonides, the Guide for the Perplexed, trans. M. Friedländer (London: George Routledge \& Sons, 1904), II. 42; quoted by Kohler and Blau, "Bat Kol”; cf. Isidore Singer and Cyrus Adler, Jewish Encyclopedia (New York: Funk \& Wagnalls Co., 1901), 588-592.

${ }^{434}$ Is believed to be Antiochus IX Eusebes, the Seleucid king.
} 


\section{Conclusion}

Throughout this chapter, I presented samples from various types of categories which I believe represent common themes. The first pertained to the bat kol announcing entry into the world to come or ratification that "so and so" is destined for the world to come. This is most emphatically declared upon a righteous person dying or being put to death, as in the case of R. Akiva, with the standard phrase, "so-and-so is destined to the world to come!” Several stories weave together details that may be understood to be based on historical realities: ${ }^{435}$ wicked governments, persecution of the Jews and the outlawing of Torah teaching.

Correspondingly, the following section analyzed instances when individuals were praised for their merit. Stories were recorded in which rabbis renowned for their humility, modesty, and kindness were picked out as worthy recipients of God's Holy Spirit. In the case of humble R. Hanina b. Dosa, three times the story of his divine endorsement as "God's son" is found in the Bavli. His merit was so great that it sustained the entire world. It seemed that the rabbis enjoyed sharing these stories in which the good deeds of men were greatly praised. Equally, evil deeds committed by men were seen as signs of much greater depravity. The rabbis worked on the assumption that deeds of a certain type, whether good or bad, were conducive to more of that same behavior, which is why these stories speak the way they do concerning various characters. Nebuchadnezzar is one of the iconic figures in this category, along with

\footnotetext{
${ }^{435}$ Especially during the mid-second century CE.
} 
several other characters from the Biblical period as well as from antiquity that was portrayed as being highly immoral. The bat $\mathrm{kol}$ is attested to having been active during the Biblical period as well as during the times of the sages.

The bat kol may have had some Halachic say, though such an idea was swiftly torn down as evidenced by the words of R. Joshua. Mishnaic statements seem to support the validity of a bat kol in echoing the death of a woman's husband. The school of Hillel allegedly permitted it while the school of Shammai rejected it. Later, when the two schools reached an impasse of sorts, the bat kol eased the tension by publicly endorsing the more gentile school of Hillel. This story apparently became well known since, it is alluded to in various other stories that depict the contrasting view of Hillel and Shammai on any given matter. The authority of the bat kol was not strong enough to overturn legal decisions, at least according to the story of the "oven of Aknai." Nevertheless, the story recounts how unsettled the world became due to R. Eliezer’s anger, to the point of killing his wife’s brother, R. Gamaliel.

There are other tales which vary in their message ${ }^{436}$ such as the story depicting a bat kol sounding off in the Holy of Holies with encouraging news to the priest. We may infer that the text is implying that the service of John Hyrcanus and Simon the Righteous was somehow related to the military victories granted by God. Other types include more

\footnotetext{
${ }^{436}$ In other parts of rabbinic writings we find a small number of cases where the bat kol is appealed to as a form of direction and or guidance. Gustaf Dalman made the distinction of two voices: the supernatural phenomenon and the chance-like utterances; cf. Gustaf Dalman and D.M. Kay, The Words of Jesus Considered in the Light of Post-Biblical Jewish Writings and the Aramaic Language (Edinburgh: T. \&T. Clark., 1902), 205.
} 
fable like stories of a rabbi outwitting the angel of death in withholding his knife from him, and the secrecy of the identity of the Messiah. ${ }^{437}$

I have sought to locate the stories into well-formed categories, despite the fact that some stories may be placed in more than one category. I have sought to prove some other functions not typically spoken of in regards to the bat kol, namely its place to announce judgment and its affiliation with Halachic episodes. Moreover, I confirm what K. Lindbeck has already pointed out as two primary functions of the bat kol: announcing someone’s earning eternal life, and praising an individual for their merit. ${ }^{438}$ Common themes and other literary features seem to reveal a creative editorial hand, by weaving together important themes, in more than one story. The final chapter will be a summary and a final analysis of the phenomenon of the bat kol.

${ }^{438}$ Lindbeck, Elijah, 55-56. 


\section{CONCLUSION}

There are numerous ways to further this investigation. For one, exploring and analyzing the vast number of instances found in Midrashic literature. ${ }^{439}$ Tannaitic Midrashim are said to be from the period of the Tannaim (ca. mid-first century BCE to third century CE) with only four full extant traditions; two from the school of R. Akiva and two from the school of R. Ishmael. ${ }^{440}$ Moreover, there are other aspects surrounding the bat kol that went unaddressed, such as stories depicting a bat kol going forth daily from Mt. Horeb, ${ }^{441}$ and the few examples of its oracular use. In addition, I am intrigued by the parallels with Gospel literature and other Christian documents. ${ }^{442}$ Granted, these should be understood on their terms, such as authorship and intended audience. However, in my opinion these two camps should not be read in isolation to one another. Essentially, these two groups vied for the rightful claim as the followers of the religion of Israel. Throughout this study I only referenced obvious similarities without adding further detail. Nevertheless, I hope to have presented new perspectives in the study of legend in rabbinic texts.

\footnotetext{
${ }^{439}$ To my knowledge there are a little less than three hundred references the majority of which are called Haggadic Midrashim; two are in Halachic Midrashim.

${ }^{440}$ They are believed to have been written somewhere around the fifth century CE. Cf. Louis Finkelstein “the Sources of the Tannaitic Midrashim,” The Jewish Quarterly Review 31 (3) (1941), 211. Louis Ginzberg has noted that many Jewish works that were rejected by the synagogue were in fact adopted by the Church. See Louis Ginzberg, Legends of the Jews, vol. I (Philadelphia: Jewish Publication Society, 1954), xii.

${ }^{441}$ Sometimes identified as synonymous with Mt. Sinai.

${ }^{442}$ Also of interest is Eusebius' account of Polycarp's martyrdom in which a "heavenly voice" appears. Some scholars believe it to be dated to the second century CE. Candida Moss argues for an early-third century date in her article "On the Dating of Polycarp: Rethinking the Place of Martyrdom of Polycarp in the History of Christianity” Early Christianity (2010), 539-574.
} 
The purpose of this inquiry was to carefully examine the presence of the bat kol in the Bavli (Babylonian Talmud). Despite being an ancient document, the Talmud (and specifically the Bavli) remains central to the practice and thought of Judaism. Within this voluminous work is Haggadah (rabbinic lore). I have analyzed the Haggadah based on factors such as genre, language, and historical connections in order to best account for them. It appears that the concept of the bat kol endures in some works of Jewish mysticism and philosophy, such as those by Judah Loew ben Bezalel (Maharal) who lived in the sixteenth century CE. ${ }^{443}$ Furthermore, the remembrance of the "ten martyrs" at certain solemn points of the year (i.e., Yom Kippur and Tish b'av) includes reading the accounts of the sages who were murdered during the first three hundred years of the CE in which the bat kol plays a central role.

The rabbis asserted to have inherited divine authority to implement, revoke, and adjudicate life for the Jewish people. In part, this was facilitated primarily by the national calamities of the destruction of the Temple in 70 CE and the Bar Kochhba rebellion and its subsequent defeat in $135 \mathrm{CE}$. Such events gave way for the need of unification and stability for the Jewish people as reflected in rabbinic writings. Means of reconciling evil and suffering had to be made available. A favorite didactic tool of the rabbis was Haggadah which connected concerns about the present with the past and the future. The stories of the bat kol visibly reflect traditional underpinnings of rabbinic lore and legend, such as depicting individuals as overly righteous or wicked in their tales.

\footnotetext{
${ }^{443}$ Some of his works which include this topic include Netzach Yisrael ("Eternity of Israel") and Be'er haGolah ("The Well of the Diaspora").
} 
Therefore, these stories may be more accurately understood not as precise historical narratives but creative and didactic homilies. Notwithstanding, historical figures and tropes, such as persecution of the Jewish people by the Romans and the outlawing of the public teaching of Torah are interwoven in these stories.

\section{Summary of LITERATURE REVIEW chapter}

The literature review highlighted the contributions of numerous and important scholarly works. Most identify the bat kol as a form of prophecy. That is to say, it differs from Biblical prophecy in terms of message and form of inspiration which may explain the cognomen bat. The bat kol is not personal and it does not instruct an individual to deliver a message to the people, rather it is often depicted appearing publicly and addressing a specific individual. A few scholars, have suggested categories based on recurring themes in the stories. I have fleshed out a category of individual praise and rebuke, while acknowledging that some stories exhibit their own unique function for the voice from heaven; such as preserving the identity of the Messiah, announcing that "so and so" is destined to marry "so and so" forty days before a child is born, and inciting Herod to rebel against his Hasmonean slave masters.

\section{Summary of ORIGINS chapter}

This chapter sought to make connections with other relevant, contemporaneous literatures. Once again I found the most resemblance with Biblical stories and Second Temple apocalyptic works. Hellenistic sources also exhibit themes pertinent to the bat kol; voices echoing from temples and panegyric stories, however these were not explored in-depth. 
In addition, though we do not find the wording "daughter of a voice" in any other work we did observe parallel functions. Perhaps the most convincing case stems from the book of Daniel where a voice from heaven addresses Nebuchadnezzar with a word of judgment. I noticed how the bat kol is similarly employed, including the same Biblical character. The stories of Isaac and Ishmael, also offered insight as to the random appearance of a heavenly voices. Interestingly enough, the identity of the speaker is ambiguous, at certain points referring to God's messenger and in other points describes God speaking in the first-person.

In addition, the anonymity of the speaker protects against possible heresies that may derive from such a messenger, such as misconstruing the agent as an equal power with God. ${ }^{444}$ In other words the rabbis may have attributed to this "voice" a less authoritative title in order for it not to be automatically construed with the Holy Spirit or God's own voice. Hence, this may explain the reasoning behind the selecting the term bat (lit. daughter); even though the bat kol is sometimes used interchangeably with God and the Holy Spirit. In this fashion, it mimics the mystery of God's theophanies in the Biblical time period when at times God's messenger spoke in His very place and with His authority. The following chapter will explore discernable categories within the text of the Babylonian Talmud.

\footnotetext{
${ }^{444}$ See the story of Elisha ben Abuyah, “Acher” in B. Chagigah 15a where he is punished for mistakenly assuming that there were two powers in heaven.
} 


\section{Summary of CATEGORIES chapter}

Throughout the chapter on categories summary, I presented samples from various types of categories which I believe represent common themes. The first pertained to the bat kol announcing entry into the world to come or ratification that "so and so" is destined for the world to come. This is most emphatically declared upon a righteous person dying or being killed, with the standard phrase, "so-and-so is destined to the world to come!” Several stories weave together details that may be understood to refer to historical realities: ${ }^{445}$ wicked governments, persecution of the Jews and the outlawing of Torah teaching.

Stories were also recorded in which rabbis known for their humility, modesty, and kindness were picked out as worthy recipients of God's Holy Spirit via the bat kol. We find these views repeated in other parts of the rabbinic milieu. It seems that the rabbis enjoyed sharing these stories in which noble individuals were generously praised. Conversely, evil individuals were considered seriously depraved. The rabbis greatly expounded on individual behavior for better or for worse. Nebuchadnezzar is an iconic figures in this category who is even associated with Titus (the Roman general attributed with destroying the Temple in $70 \mathrm{AD}$ ). The bat kol repeatedly informs these two characters of their due penalties. The bat kol is attested to having been active during the Biblical period as well as during the times of the sages in these stories.

\footnotetext{
445 This was especially so during the Hadrianic persecutions during the mid-second century CE.
} 
The bat kol is also read in discussions pertaining to Halacha. Mishnaic statements seem to support the validity of a bat kol in pronouncing the death of a woman's husband. The school of Hillel permitted it while the school of Shammai did not. ${ }^{446}$ Later, when the two schools reached an impasse of sorts, the bat kol eased the tension by publicly endorsing the more lenient-ruling school of Hillel. This story apparently became well known since, it is alluded to in various other stories that depict the contrasting view of Hillel and Shammai on any given matter. The authority of the bat kol was not strong enough to overturn legal decisions, at least according to the story of the "oven of Aknai." Nevertheless, the story recounts how the world suffered due to the injustice R. Eliezer suffered on the behalf of his colleagues.

There are other tales which vary in their message and do not neatly fit into one of the aforementioned subgroups. ${ }^{447}$ This includes incidents such as the story which depicts the bat kol sounding off in the Holy of Holies with good news for the priest. Others include more fable-like stories of a rabbi outwitting the angel of death and procuring his knife, and the preservation of the hidden identity of the Messiah. ${ }^{448}$

I have sought to prove some other functions not typically spoken of in regards to the bat kol, namely its place to announce judgment and its affiliation with Halachic

\footnotetext{
446 They were two major schools of law from the first century BCE to the first century CE, who often debated points of jurisprudence with one another as found in the Talmud.

${ }^{447}$ In other parts of rabbinic writings we find a negligible among of cases where the bat kol is appealed to as a form of direction and or guidance. Gustaf Dalman made the distinction of two voices: the supernatural phenomenon and the chance-like utterances; cf. Gustaf Dalman and D.M. Kay, The Words of Jesus Considered in the Light of Post-Biblical Jewish Writings and the Aramaic Language (Edinburgh: T. \&T. Clark., 1902), 205.
} 
episodes. However, in accordance with the view of scholars like K. Lindbeck, two central functions of the bat kol are clear: announcing someone's entrance into eternal life, and praising an individual for their merit or lack thereof. ${ }^{449}$ Common themes and other literary features seem to reveal a creative editorial hand, by weaving together important themes in more than one story.

\section{Concluding Remarks}

Through the cases reviewed in this study, it is clear that the bat kol's primary function is a type of herald. From enunciating panegyric phrases to capturing God's own regret and dismay. It served the function of a type of megaphone, employed primarily to denote individuals and their actions. Its role was crucial considering the rabbinic notion that prophecy had indeed “ceased.” Interestingly enough, in another place in the Talmudic body of writings we find a statement asserting that prophecy had indeed continued through the chahmim (lit. wise men). In Bava Batra 12a it reads that after the destruction of the Temple prophecy was taken from the prophets and given over to the sages and that a sage is greater than a prophet. ${ }^{450}$ Thus, we find both the claim that after the latter prophets the bat kol became the conduit of revelation and also that the rabbis were endowed with the gift of prophecy as well. In my view, I find these statements to be asserting the principle that the rabbis were the arbiters of what constituted valid prophetic messages. Moreover, in the rabbis' description and retelling stories of the bat

\footnotetext{
${ }^{449}$ Lindbeck, Elijah, 55-56.

${ }^{450}$ B. Bava Batra 12b reads R. Yochanan said that after the destruction of the Temple prophecy has been taken from prophets and given to fools and children. Thanks to Hacham Yehonatan Elazar-DeMota for this reference.
} 
kol they were in fact exercising their own prophetic in a clandestine manner. Therefore, via oral tradition and later writings, these stories afforded the people to hear actual words from God in a riveting and personal manner. The stories carried great relevance and genius by synthesizing ancient Biblical writings with contemporary motifs, the result was a highly-relevant exegesis.

Moreover, as with Haggadah in general, we can discern a direct correlation between the messages articulated by the bat kol and the prerogatives of the rabbis. Here there is considerable overlap. The bat kol condemned characters associated with the destruction of both the First and Second Temples. It praised sages who suffered martyrdom because of their defiance of Rome by continuing to publicly teach their laws. It also praised individuals who were distinguished for their character, articulating their worthiness to receive God's abiding presence. Nevertheless, it seems reasonable to conclude that in ancient Jewish Palestine, the belief in hearing an audible expression of God's voice was a reality. This is supported by other writers who make mention of heavenly voices (e.g., Josephus and the Gospel writers). Moreover, many of the stories reviewed include the prefatory comments "our rabbis taught” which reveals its Tannaitic provenance. ${ }^{451}$ This is indicative both of the geographical region (Jewish Palestine), and the date (first to early third century CE).

Just like Elijah, who appears in many Talmudic legends, the "daughter of a voice" intermittently manifests yet with specific purposes. We may discern a literary and or

\footnotetext{
${ }^{451} \mathrm{Rab}$ Judah (third century) is the one often retelling the stories of the bat kol in the name of one of his two teachers, Rav and Shemuel. This line is connected with R. Judah ha-Nasi himself, who was a major leader/ruler in the second century and who also produced the Mishnah.
} 
phenomenological appreciation for such a sign. Its presence as attested to in the earliest rabbinic documents (Mishnah, Tosefta) hints that it was recognized as influential upon remarriage, at least within the rabbinic fold, during the first few centuries CE and its inclusion in the Bavli suggests the later Amoraim sought to preserve and propagate these stories.

Nor was the destruction of the Temple sufficient reason for the rabbis to perceive God as far removed (though they certainly allude to this idea). Indeed, the notion of the “voice from heaven” asserts that God was invested in His people. It is never outright called the voice of the "Holy Spirit" or of God himself. Its cognomen implies a different and separate entity from the Almighty. In this way, the heavenly echo, whether supposedly the voice of an angelic figure or of another supernal being, resonated in the ears of the common people; perhaps literally as well as figuratively.

The "voice from heaven" may be construed as being polyvocal. That is to say, the stories are recapitulated, vis-a-vis the rabbis, which mirror rabbinic thought and teaching. In a way, the revelation conferred to Moses at Mt. Sinai, more than a thousand years ago prior to the sages, reverberates throughout Jewish history so that the leaders of the nation would be both the recipients and transmitters of God's revelatory voice. Thus, we may describe such a development as "What started in heaven ends on earth." ${ }^{452}$ In other words, the process through which heavenly messages are filtered down to earth culminate in its being preserved and propagated via the voices of those entrusted with

\footnotetext{
452 Prof. James Kugel used this expression in a lecture entitled "Modern Scholarship and Traditional Jewish Belief" at a 2013 Limmud conference.
} 
such sacred oracles. In my opinion, these stories may be interpreted as a synthesis of God's voice and the sages'. Consequently, when we read (or hear the voice) of the bat kol we, in fact, are reading or hearing the voices of the rabbis.

\section{BIBLIOGRAPHY}

Abbott, Edwin Abbott. From Letter to Spirit; an Attempt to Reach through Varying Voices the Abiding Word. London: A. and C. Black, 1903.

Abegg, Martin G., Jr., Peter W. Flint, and Eugene Ulrich. The Dead Sea Scrolls Bible: The Oldest Known Bible. San Francisco, CA: HarperOne, San Francisco, 1999.

Aune, David Edward. Prophecy in Early Christianity and the Ancient Mediterranean World. Grand Rapids, Mich.: Eerdmans, 1983.

Bader, Gershom. The Encyclopedia of Talmudic Sages. Northvale, N.J.: Jason Aronson, 1988.

Becker, Adam H., and Annette Yoshiko Reed. The Ways That Never Parted: Jews and Christians in Late Antiquity and the Early Middle Ages. Tübingen: Mohr Siebeck, 2003.

Bieringer, Reimund, ed. The New Testament and Rabbinic Literature. Leiden: Brill, 2010.

Bockmuehl, Markus N. A. Revelation and Mystery in Ancient Judaism and Pauline Christianity. Tübingen: J.C.B. Mohr, 1990.

Boyarin, Daniel. Border Lines: The Partition of Judaeo-Christianity. Philadelphia: University of Pennsylvania Press, 2004. . Dying for God: Martyrdom and the Making of Christianity and Judaism. Stanford, CA: Stanford University Press, 1999. .Intertextuality and The Reading of Midrash. Bloomington, IN: Indiana University Press, 1990.

Chajes, Z.H. The Student's Guide through the Talmud. New York: Philipp Feldheim, 1960. 
Chernick, Michael L., ed. Essential Papers on the Talmud. New York: New York University Press, 1994.

Coggins, R. J., and Michael A. Knibb. The First and Second Books of Esdras. Cambridge: Cambridge University Press, 1979.

Cohen, Shaye J.D.. 1984. "The Significance of Yavneh: Pharisees, Rabbis, and the End of Jewish Sectarianism”. Hebrew Union College Annual 55. Hebrew Union College - Jewish Institute of Religion: 27-53. http://www.jstor.org/stable/23507609.

Collins, John J. The Apocalyptic Imagination: An Introduction to Jewish Apocalyptic Literature. Grand Rapids, MI: William B. Eerdmans, 1998. ., Frank Moore Cross, and Adela Yarbro Collins. Daniel: A Commentary on the Book of Daniel. Minneapolis: Fortress Press, 1993.

Cook, L. Stephen. On the Question of the "Cessation of Prophecy" in Ancient Judaism. Tübingen: Mohr Siebeck, 2011.

Dalman, Gustaf, and D. M. Kay. The Words of Jesus Considered in the Light of PostBiblical Jewish Writings and the Aramaic Language,. Authorized English Version by D.M. Kay. ed. Edinburgh: T. \& T. Clark, 1902.

Deland, Adrien. Antiquitates Sacrae Veterum Hebraeorum. Quarta ed. Broadelet: Traiecti Ad Rhenum: Ex Libraria Ioannis Broedelet, 1741.

Epstein, Isidore, ed. Berakhot: Translated into English with Notes, Glossary and Indices. Translated by Maurice Simon. London: Soncino Press, 1948. . Hebrew-English edition of the Babylonian Talmud. London: Soncino, 1960.

Feldman, Louis H. and Meyer Reinhold. Jewish Life and Thought among Greeks and Romans: Primary Readings. Minneapolis: Fortress Press, 1996.

Finkelstein, Louis. 1941. “The Sources of the Tannaitic Midrashim”. The Jewish Quarterly Review 31 (3). [University of Pennsylvania Press, Center for Advanced Judaic Studies, University of Pennsylvania]: 211-43. doi:10.2307/1452573.

Fisch, Menachem. Rational Rabbis: Science and Talmudic Culture. Indianapolis: Indiana University Press, 1997. 
Fishbane, Michael. Biblical Interpretation in Ancient Israel. Oxford: Clarendon Press, 1985.

Flesher, Paul Virgil McCracken., and Bruce Chilton. The Targums: A Critical Introduction. Waco, TX: Baylor University Press, 2011.

Gfröer, August Friedrich. Das Jahrhundert des Heils. Schweizerhart's Verlagshandlung, 1883.

Ginzberg, Louis. Legends of the Jews. Translated by Henrietta Szold. Vol. 1. Philadelphia: Jewish Publication Society, 1954.

1922. "Some Observations on the Attitude of the Synagogue Towards the Apocalyptic-eschatological Writings”. Journal of Biblical Literature 41 (1/2). Society of Biblical Literature: 115-36. doi:10.2307/3259243.

Glatzer, Nahum N. Essays in Jewish Thought. University: University of Alabama Press, 1978.

Goldwurm, Hersh. Talmud Bavli = [Talmud Bavli] : The Schottenstein Edition : The Gemara : The Classic Vilna Edition, with an Annotated, Interpretive Elucidation, as an Aid to Talmud Study. Brooklyn, N.Y.: Mesorah Publications, 1990.

Gottstein, Alon Goshen. The Sinner and the Amnesiac: The Rabbinic Invention of Elisha Ben Abuya and Eleazar Ben Arach. Stanford, CA: Stanford University Press, 2000 .

Gray, Rebecca. Prophetic Figures in Late Second Temple Jewish Palestine: The Evidence from Josephus. New York: Oxford University Press, 1993.

Greenspahn, Frederick E.. 1989. “Why Prophecy Ceased”. Journal of Biblical Literature 108 (1). Society of Biblical Literature: 37-49. doi:10.2307/3267469.

Grossfeld, Bernard. The Aramaic Bible: The Two Targums of Esther. Vol. 18. Collegeville: Liturgical Press, 1991.

Guttmann, Alexander. Rabbinic Judaism in the Making: A Chapter in the History of the Halakhah from Ezra to Judah I. Detroit: Wayne State University Press, 1970. . 1947. “The Significance of Miracles for Talmudic Judaism.” Hebrew Union College Annual 20. Hebrew Union College - Jewish Institute of Religion: 363-406. http://www.jstor.org/stable/23506468.

Harlow, Daniel C. The Greek Apocalypse of Baruch (3 Baruch) in Hellenistic Judaism 
and Early Christianity. New York: E.J. Brill, 1996.

Hartman, Geoffrey H., and Sanford Budick, eds. Midrash and Literature. New Haven, CT: Yale University Press, 1986.

Herford, R. Travers. Christianity in Talmud and Midrash,. Clifton, N.J.: Reference Book Publishers, 1966.

Herlitz, Georg, and Bruno Kirschner. Jüdisches lexikon; ein enzyklopädisches Handbuch des jüdischen Wissens in vier bänden mit über 2000 Illustrationen, Beilagen, Karten und Tabellen. Berlin: Jüdischer Verlag, 1927.

Heschel, Abraham Joshua. Prophetic Inspiration after the Prophets: Maimonides and Other Medieval Authorities. Edited by Morris M. Faierstein. Hoboken, NJ: Ktav, 1966.

Holladay, William L. A Concise Hebrew and Aramaic Lexicon of the Old Testament: Based upon the Lexical Work of Ludwig Koehler and Walter Baumgartner. Leiden: Brill, 1971.

Holtz, Barry W., ed. Back to the Sources: Reading the Classic Jewish Texts. New York: Summit Books, 1984.

Howland, Jacob. Plato and the Talmud. Cambridge: Cambridge University Press, 2011.

Hubbard, B. A. F., E. S. Karnofsky, and Plato. Plato's Protagoras: A Socratic Commentary. Chicago: University of Chicago Press, 1984.

Israel, Azzan Y. Scripture and Tradition: Rabbi Akiva and the Triumph of Midrash. Philadelphia: University of Pennsylvania Press, 2015.

Jacobs, Louis. The Jewish Religion: A Companion. Oxford: Oxford University Press, 1995. eBook Collection (EBSCOhost), EBSCOhost.

Jassen, Alex P. Mediating the Divine Prophecy and Revelation in the Dead Sea Scrolls and Second Temple Judaism. Leiden: Brill, 2007.

2008. "Prophets and Prophecy in the Qumran Community". AJS Review 32 (2). [Cambridge University Press, Association for Jewish Studies]: 299-334. http://www.jstor.org/stable/27564361.

Jastrow, Marcus. A Dictionary of the Targumim, the Talmud Babli and Yerushalmi, and the Midrashic Literature. London: Trübner, 1886. 
Josephus, Flavius, William Whiston, and Flavius Josephus. The Works of Flavius Josephus: Comprising the Antiquities of the Jews, a History of the Jewish Wars, and Life of Flavius Josephus, Written by Himself. Philadelphia, Pa: Jas. B. Smith \& Co, 1854.

Kadushin, Max. The Rabbinic Mind (3d ed.). New York: Bloch Pub., 1972.

Kalmin, Richard. Sages, Stories, Authors, and Editors in Rabbinic Babylonia. Atlanta: Scholars Press, 1994. . The Sage in Jewish Society of Late Antiquity. New York: Routledge, 1999.

Kirkpatrick, William. A Vocabulary, Persian, Arabic, and English Containing Such Words as Have Been Adopted from the Two Former of Those Languages, and Incorporated into the Hindvi: ... Being the Seventh Part of the New Hindvi Grammar and Dictionary. By William Kirkpatrick. London: Printed by Joseph Cooper, 1785.

Kirschner, Robert. "Apocalyptic and Rabbinic Responses to the Destruction of 70." The Harvard Theological Review, 2nd ser., 78, no. 1 (1985): 27-46.

Kittel, Gerhard, G. W. Bromiley, and Gerhard Friedrich. Theological Dictionary of the New Testament. Vol. IX. Grand Rapids, MI: Eerdmans, 1974: 278-301.

Kitto, John, ed. The Cyclopeedia of Biblical Literature. $10^{\text {th }}$ ed. Vol. I. New York: Ivison \& Phinney, 1858.

Koren Talmud Bavli Tractate Eiruvin, Daf Yomi B \& W Edition. Koren Pub, 2013.

Kuhn, Peter. Offenbarung Stimmen im Antiken Judentum: Untersuchungen zur Bat Qol und verwandeten Phänomen. Mohr Siebeck, 1989.

Lieberman, Saul. Hellenism in Jewish Palestine; Studies in the Literary Transmission, Beliefs and Manners of Palestine in the I century B.C.E.-IV century C.E. New York: Jewish Theological Seminary of America, 1950.

Lightfoot, John. Horce Hebraicce et Talmudicce; Hebrew and Talmudical exercitations upon the Gospels, the Acts, some chapters of St. Paul's Epistle to the Romans, and the First epistle to the Corinthians. Vol. II. Oxford: University Press, 1859.

Lindbeck, Kristen H. Elijah and the Rabbis: Story and Theology. New York: Columbia University Press, 2010.

Lindblom, Johannes. Vorstellungen von göttlichen Weisungen und übernatürlichen 
Erscheinungen im ältesten Christentum. Lund: Gleerup, 1968.

Maimonides, Moses. The Guide for the Perplexed. Translated by M. Friedländer. 2nd ed. London: George Routledge \& Sons, 1904.

Marmorstein, Arthur. Studies in Jewish theology; the Arthur Marmorstein memorial Volume. London: Oxford University Press, 1950.

Moore, George Foot. Judaism in the First Centuries of the Christian Era: The Age of the Tannaim. Vol. I-II. Cambridge: Harvard University Press, 1927.

Moss, Candida R. 2010. "On the Dating of Polycarp: Rethinking the Place of the Martyrdom of Polycarp in the History of Christianity." Early Christianity 1, no. 4: 539-74.

Newman, Barclay Moon. A Concise Greek-English Dictionary of the New Testament. London: United Bible Societies, 1971.

Neusner, Jacob. From Politics to Piety; The Emergence of Pharisaic Judaism. Englewood Cliffs, N.J.: Prentice-Hall, 1972. . The Discourse of the Bavli: Language, Literature, and Symbolism. Atlanta: Scholars Press, 1991.

Nikolsky, Ronit, and Țal Ilan, eds. Rabbinic Traditions between Palestine and Babylonia. Boston: Brill, 2014.

Parzen, Rabbi Herbert. 1929. "The Ruah Haḳodesh in Tannaitic Literature”. The Jewish Quarterly Review 20 (1). University of Pennsylvania Press: 51-76. doi:10.2307/1451514.

Patai, Raphael. Gates to the Old City: A Book of Jewish Legends. Detroit: Wayne State University Press, 1981.

Rajak, Tessa. The Jewish Dialogue with Greece and Rome: Studies in Cultural and Social Interaction. Leiden: Brill, 2002.

Reland, Adrien, Tomas F. Arteta, F. Bleiswyk, and Johan Broedelet.Antiquitates Sacrae Veterum Hebraecorum Breviter Delineatae Ab Hadriano Renando. 4th ed. Trajecti Ad Rhenum: Broedelet, 1741.

Rothkoff, Aaron. "Bat Kol." In Encyclopaedia Judaica, edited by Berenbaum, Michael and Fred Skolnik. 2nd ed. ed. Vol. 3, 213. Detroit: Macmillan Reference USA, 2007. 
Rubenstein, Jeffrey. Talmudic Stories: Narrative Art, Composition, and Culture. Baltimore: The Johns Hopkins University Press, 1999.

Russell, D.S. The Method and Message of Jewish Apocalyptic: 200 BC-AD 100. Philadelphia: The Westminster Press, 1964.

Scheidt, Balthaser, Johann Andreas Danz, Jacob Rhenferd, and Johann Gerhard Meuschen. Novum Testamentum ex Talmude et antiquitatibus Hebrcorum illustratum. Lipsiæ: apud hær. J.F. Braunii, 1736.

Schiffman, Lawrence H. From Text to Tradition: A History of Second Temple and Rabbinic Judaism. Hoboken, NJ: Ktav Pub. House, 1991. . Reclaiming the Dead Sea Scrolls: The History of Judaism, the Background of Christianity, the Lost Library of Qumran. Philadelphia: Jewish Publication Society, 1994.

Schwartz, Howard. Tree of Souls: The Mythology of Judaism. Oxford: Oxford University Press, 2004.

Sherwin, Bryan L. Workers of Wonders: A Model for Effective Religious Leadership from Scripture to Today. Lanham, MD: Rowman \& Littlefield Publishers, 2004.

Singer, Isidore, and Cyrus Adler. The Jewish Encyclopedia: A Descriptive Record of the History, Religion, Literature, and Customs of the Jewish People from the Earliest Times to the Present Day. Vol. II. New York: Funk \& Wagnalls Company, 1901.

Sperling, David. "Akkadian Egerru and Hebrew Bt Qwl." Journal of Near Eastern Studies 4 (1972): 63-74. http://www.jtsa.edu/Documents/pagedocs/JANES/1972 4/Sperling4.pdf.

Steinsaltz, Adin. Talmudic Images. Northvale, NJ: Jason Aronson, 1997.

.The Essential Talmud. New York: Basic Books, a member of the Perseus Books Group, 2006.

Stoneman, Richard. The Ancient Oracles: Making the Gods Speak. New Haven, CT: Yale University Press, 2011.

Torah, Nevi'im, Ketuvim Yeha-Berit Ha-Hadashah: 'Ivrit Ve-Anglit = The Holy Scriptures: Hebrew and English (NKJV). Jerusalem: I.A.D.B.W and B.S.I, 1997.

Society of Bib. Arch. 1893. "Ancient Traditions of Supernatural Voices (Bath-Kol)" Transactions of the Society of Biblical Archaeology. Vol. 9. London. 182194. http://babel.hathitrust.org/cgi/pt?id=uc1.b3040723;view=1up;seq=9. 
Trattner, Ernest R. Understanding the Talmud. New York: T. Nelson, 1955.

VanderKam, James C. Enoch and the Growth of an Apocalyptic Tradition. Washington, D.C.: Catholic Biblical Association of America, 1984.

."Mantic Wisdom in the Dead Sea Scrolls." Dead Sea Discoveries 4, no. 3 (1997): 336-53.

Vermes, Geza. Who's Who in the Age of Jesus. London: Penguin Books, 2006.

Vitringa, Campegius. Observationes Sacrae: Libri Quintus \& Sextus in Quibus De Rebus Varii Argumenti ... Theologice Ac Critice, Disseritur : Sacrorum Imprimis Librorum Loca Multa Obscuriora Nova Vel Clariore Luce Perfunduntur. Franequerae: Bleck, 1708. 